Pós-Graduação em Medicina Tropical

Instituto de Medicina Tropical de São Paulo, São Paulo, Brasil

\title{
POLÍTICAS PÚBLICAS DE CUSTO MÍNIMO DE SEGURO SAÚDE NO TURISMO RECEPTIVO NA ÁREA SCHENGEN: CAUSAS E CONSEQUÊNCIAS
}

Dennis Minoru Fujita

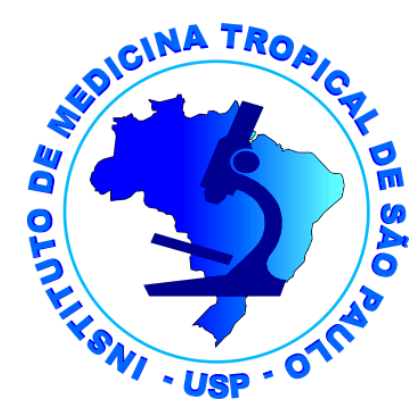

São Paulo 2018 


\section{POLÍTICAS PÚBLICAS DE CUSTO MÍNIMO DE SEGURO SAÚDE NO TURISMO RECEPTIVO NA ÁREA SCHENGEN: CAUSAS E CONSEQUÊNCIAS TESE DE DOUTORADO}

Por

\section{Dennis Minoru Fujita}

Orientador:

Prof. Dr. Heitor Franco de Andrade Júnior IMT-USP

Departamento - Protozoologia

\section{Banca Examinadora:}

Profa. Dra. Célia Maria de Moraes Dias ECA-USP

Departamento - Turismo

Prof. Dr. Expedito José de Albuquerque Luna IMT-USP

Departamento - Epidemiologia

Prof. Dr. Luiz Hernan Contreras Pinochet UNIFESP

Departamento - Administração

Profa. Dra. Rita de Cássia Giraldi EACH - USP

Departamento - Lazer e Turismo 
Aos meus pais e irmã (Marion) pelo constante apoio

À Amanda Medina por me apoiar nestes anos de intensa atividade e nervosismo Aos valiosos e imprescindíveis conhecimentos transmitidos pelos meus orientadores Dr. Heitor Franco de Andrade Júnior e Dr. Expedito José de Albuquerque Luna

Aos meus amigos de discussão, em especial Dr. Andrés Gimenez Galisteo Jr., Dr. Luiz Henrique da Silva Nali, MSc. Felipe Scassi Salvador e Dr. Paulo Roberto Palma Urbano que me ajudaram a compreender o mundo da saúde coletiva e embarcaram em algumas de minhas ideias!

Aos amigos do laboratório de Protozoologia/LIM-49, Me. Marilda Savoia, Dra. Luciana Meirelles, Dr. Norival Kesper, Dra. Camila Carvalho, MSc. Jaqueline Polizeli, MSc. Andréa Costa, Thiago Fidellis e a inestimável Rose que me acolheram tão bem nesta casa.

Agradeço a todos do Instituto de Medicina Tropical de São Paulo, bem como de outras instituições que de alguma forma, direta ou indiretamente contribuíram para a minha formação atual! 


\title{
RESUMO
}

\author{
FUJITA, Dennis Minoru. Políticas públicas de custo mínimo de seguro saúde no \\ turismo receptivo na área Schengen. Causas e consequências. Tese de Doutorado - \\ INSTITUTO DE MEDICINA TROPICAL DE SÃO PAULO-UNIVERSIDADE DE \\ SÃO PAULO, São Paulo, 2018.
}

As áreas tropicais são consideradas propensas a doenças infecciosas e recentemente apresentaram desenvolvimento econômico com aumento do turismo doméstico e internacional de seus habitantes. Há um aumento de viagens internacionais com maior risco potencial para a importação de doenças, particularmente nos últimos 10 anos, e o novo quadro de surtos globais no século 21. A promoção de viagens seguras destes turistas no destino é um novo desafio para os governos receptores. Alguns países desenvolvidos com tradição turística, como os signatários da Convenção Schengen, implementaram políticas para lidar com o eventual custo de saúde de viajantes de áreas tropicais. Outros destinos, como os Estados Unidos, mantiveram suas políticas de saúde para turistas. Visando identificar a real condição de saúde destes novos turistas de países emergentes, estudamos os problemas de saúde dos turistas brasileiros no exterior, comparando o fluxo de viagens, o custo de saúde antes e depois da implantação da Convenção Schengen, a exposição potencial para algumas doenças infecciosas no intuito de sugerir medidas para proteção e prevenção desses viajantes brasileiros. Não há evidência de transporte de doenças por viajantes brasileiros para seus destinos turísticos. Países que adotaram seguro saúde obrigatório para os turistas brasileiros não apresentaram maiores custos de saúde, tendo queda relativa do fluxo turístico do Brasil, em comparação a países sem restrições. Além disso, o transporte aéreo e eventos internacionais de massa, como a Copa do Mundo e os Jogos Olímpicos, permitiram a transmissão de doenças para o Brasil, com introdução do vírus Zika e reintrodução do vírus do sarampo. A rápida transmissão mostra a importância das medidas preventivas que incluem o reforço da vacinação de grupos específicos, o alerta de higiene pessoal adequada e outras ações para evitar possíveis surtos devido ao elevado tráfego de viajantes nos eventos. No turismo doméstico, o potencial risco de transmissão de doenças infecciosas negligenciadas, como Leishmaniose Visceral, cuja disseminação se intensificou por deslocamento de animais de estimação; e da esquistossomose humana pelo aumento das mudanças climáticas e de atividades de lazer em áreas naturais, promovem maior exposição dos viajantes internacionais e nacionais.

A rede atual de prevenção e proteção para viajantes no Brasil, composta por clínicas de medicina de viagem, mídias com recomendações para viajantes e centros de imunização tornam-se importantes na prevenção de contágio dos turistas e reduzem consideravelmente o número de atendimentos pós-viagem. Quando usada, fornece aos viajantes brasileiros proteção para as principais doenças infecciosas preveníveis ale de orientação para se evitar situações de risco em viagem, sendo um modelo de política pública interessante. Alguns protocolos para a entrada dos viajantes demonstram ser uma atitude adequada para melhorar a segurança dos viajantes e de seus países, bem como novas medidas preventivas são necessárias para evitar a disseminação de surtos de doenças infecciosas.

Descritores: 1. Epidemiologia Descritiva. 2. Saúde Pública. 3. Políticas Públicas. 4. Política de Fronteira. 5. Turistas Estrangeiros. 6. Turistas Nacionais. 


\begin{abstract}
FUJITA, Dennis Minoru. Public policies with minimum cost for health insurance in inbound tourism at schengen area. Causes and consequences. Thesis in Tropical Medicine - São Paulo Institute of Tropical Medicine-USP, São Paulo, 2018.

Tropical areas are considered prone to infectious diseases and have recently presented economic development with increased domestic and international tourism of its inhabitants. There is an increase in international travel with greater potential risk for diseases importation, particularly in the last 10 years, a new global outbreak chart in the 21 st century. The promotion of safe travel of these tourists at destination is a challenge for recipient governments. Some developed countries with a tourist tradition, such as the Schengen Convention, have implemented policies to deal with the possible cost of health of travelers from tropical areas. Other destinations, as the United States, have maintained their health policies for tourists. Aiming to identify the real health condition of new tourists from emerging countries, we studied the health problems of Brazilian tourists abroad, comparing flow, health cost before and after the implementation of the Schengen Convention, their potential exposure to some infectious diseases, to suggest measures for protection and prevention of these Brazilian travelers. There is no evidence of diseases' transport by Brazilian travelers to their destinations. Countries that adopted mandatory health insurance for Brazilian tourists did not present higher health costs, only a relative drop in Brazil's tourism flow compared to unrestricted countries. In addition, with air transport and international mass events, such as the World Cup and the Olympic Games, allowed the importation of diseases into Brazil, with the introduction of the Zika virus and the reintroduction of the measles virus. The rapid transmission shows the importance of preventive measures that include reinforcing of vaccination, adequate personal hygiene alert, and other actions to avoid possible outbreaks due to the high traffic of travelers at events. In domestic tourism, the potential risk of transmission of neglected infectious diseases, such as Visceral Leishmaniosis, whose spread was intensified by displacement of pets; and human schistosomiasis by increasing climate change and leisure activities in natural areas, promoting greater exposure of international or national travelers. The current network of prevention and protection for travelers in Brazil, composed of travel medicine clinics, media with recommendations for travelers and immunization centers is effective in preventing infection of tourists and greatly reduces the number of post-trip visits. When used, it provides Brazilian travelers with a protection for the major preventable infectious diseases and education to avoid risky travel situations, an interesting model of public police. Some protocols for travelers' entry prove to be an appropriate attitude to improve the safety of travelers and countries, as well as new preventive measures are needed to prevent the spread of infectious disease outbreaks.
\end{abstract}

Descriptors: 1. Descriptive Epidemiology. 2. Public Health. 3. Public Policies. 4. Crossborder Policy. 5. Foreign Tourist. 6. Domestic Tourist. 


\section{RESUMO EXPANDIDO}

Esta tese é um compêndio de artigos científicos produzidos no período de 2014 à 2018 cujo tema principal foram os surtos relacionados à viajantes no Brasil, tendo-se o cuidado de caracterizar as doenças, situação epidemiológica, hipóteses ou método investigativo para a sua caracterização como endemia relativa à viajantes; e, recomendações de controle ou medidas adotadas.

Percebemos ao longo do trabalho que o viajante brasileiro é saudável, pois apresenta pouca sinistralidade em relação ao uso de seguro viagem ao exterior, medida esta protetiva adotada em viagens ao exterior, mas ainda não constituído como hábito para todos se analisarmos a proporção entre consumo de seguro viagens $\mathrm{X}$ número total de viagens, que nos apresenta um resultado ainda baixo (apenas 32\%).

O baixo resultado de sinistros nos permite aferir que o turista brasileiro tem as mesmas condições de saúde que turistas oriundos de países desenvolvidos, uma vez que temos 20\% de prevalência, média esta semelhante à estudos realizados no Canadá, Austrália e Reino Unido.

As medidas protetivas adotadas no contexto atual em virtude do aumento de participação de países emergentes $(\sim 46,8 \%)$ no cenário internacional de viagens se tornam excludentes e inibidoras, como a Convenção Schengen, sendo uma forma de seleção de público, evitando-se que potenciais indivíduos de classes menos favorecidas, e "potencialmente infectados", tenham acesso a estes países.

O crescimento de fluxo internacional e doméstico de viajantes brasileiros e a importação de doenças infecciosas como Zika Virus, Sarampo e Caxumba foi tema dos 
artigos 2 e 3, onde percebemos que há um risco real para a migração de doenças por viajantes.

A vinda do Zika Virus para o Brasil ainda é especulativa quanto as rotas possíveis de entrada, mas constituiu-se num surto de ordem mundial com o nosso país figurando como o epicentro de maior potencial de transmissão mundial devido aos grandes eventos de massa (Copa do Mundo de 2014 e Olimpíadas 2016) ocorridos no período de latência do surto.

Outras doenças como Sarampo e Caxumba foram notificadas nestes períodos, tendo como característica a vinculação ao processo de viagens. Ressaltamos que o turista é um indivíduo saudável que se torna um eventual hospedeiro e potencial importador de endemias para o Brasil, mesmo em visita a regiões consideradas "seguras" (países desenvolvidos). Este processo esta correlacionado as baixas coberturas vacinais presentes em várias regiões do mundo, incluindo-se o Brasil que apresenta este declínio desde 2016.

Novos atores se somam à equação de proteção dos viajantes como os animais domésticos que tem representado um risco potencial para a evolução de doenças como Leishmaniose Visceral que não segue mais a progressão natural, tendo-se novos focos aleatórios e de alta amplitude geográfica (Região Noroeste para o extremo litoral de São Paulo), conforme o artigo 4. Este fenômeno de tendência mundial para transmissão de doenças domésticas via terrestre gera atenção para o conceito de proteção e prevenção da saúde global devido a interligação do meio ambiente e todos os seres vivos (One Health). 
Ampliando esta discussão (artigo 5) temos novas tendências de turismo com o aumento de atividades recreativas em áreas naturais aliada as intensas mudanças climáticas gerando novos cenários de potencial exposição de viajantes para doenças negligenciadas que devido ao fenômeno global de viagens possibilitam que estas endemias locais migrem para países desenvolvidos. Esta nova configuração mundial de trânsito de viajantes permitem a conclusão que as doenças negligenciadas são agora responsabilidade de todos, sejam países desenvolvidos ou pobres devido à facilidade de circulação e transmissão de doenças.

O último artigo apresenta novamente o conceito do turista saudável, em especial o brasileiro, analisando como medidas preventivas como a consulta pré-viagem se tornam estratégias mais eficazes no controle de importação de doenças, sendo uma política publica que apresenta eficácia pela baixa incidência no atendimento pósviagem.

O perfil epidemiológico permite determinar ações estratégicas como determinar quais doenças podem surgir no país, medidas de aconselhamento de viajantes conforme o destino, meios de comunicação para atingir o publico alvo conforme a idade, e, principalmente, imunização de nossos viajantes para doenças infecciosas preveníveis em virtude da diminuição atual da cobertura vacinal no Brasil.

Uma política nacional para a proteção do viajante se torna cada vez mais necessária, principalmente pautada em informação preventiva e aprimoramento da infraestrutura atual de atendimento em virtude do futuro e constante crescimento da atividade turística. Novos estudos são necessários para criarmos esta rede protetiva que tende a se diversificar e se tornar cada vez mais complexa. 


\section{LISTA DE ARTIGOS CIENTÍFICOS}

I. Fujita DM., Nali LH da S., Urbano PR., Soeiro DM., Andrade HF de. The fast transmission of infectious diseases around the world - a new concern to the public health. Braz J Infect Dis. 2016;20(5):513-5. Doi: 10.1016/j.bjid.2016.06.003.

II. Salvador FS., Fujita DM. Entry routes for Zika virus in Brazil after 2014 world cup: New possibilities. 2016. Doi: 10.1016/j.tmaid.2015.10.004.

III. Nali LHS., Fujita DM., Salvador FS., et al. Potential measles transmission risk in mass gatherings: Are we safe for the Olympic games-Rio 2016? J Travel Med. 2016;23(4). Doi: 10.1093/jtm/taw026.

IV. Carvalho CA., Fujita DM., da Silva Nali LH., de Andrade Júnior HF., Hiramoto RM. Preventive measures for "Pet Friendly" lodging facilities: association of Leishmaniasis expansion route in São Paulo and preventive measures for regional animals displacement. J Travel Med. 2017;24(5). Doi: $10.1093 / \mathrm{jtm} / \mathrm{tax} 030$.

V. Fujita DM, Luna E, Climate Changes and Increase of Leisure Activities in Natural Areas: The Potential Risk for Parasitic Diseases - Schistosoma mansoni in Chapada Diamantina/Bahia - Brazil - 2017. Submitted manuscript 2017

VI. Fujita DM, Miyaji K, Lopes M, Andrade Jr H, Evidences on Brazilian travelers' health trough the epidemiological profile of a public travel medicine clinic - São Paulo - 2012/2016. Submitted manuscript 2017 


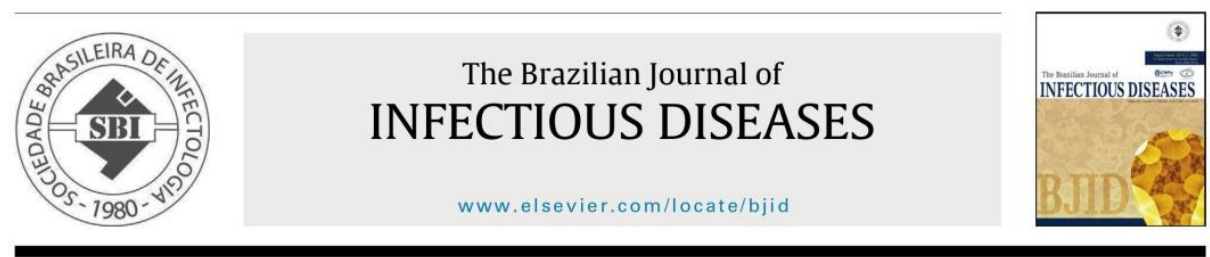

Letter to the Editor

\section{The fast transmission of infectious diseases around the world - a new concern to the public health}

Dear Editor,

The high number of people traveling around the world (1,184,000,000 trips in 2015) with 45\% participation of emerg ing countries tourists, allied to their hostage of international sportive mass gatherings events (Fig. 1A and B), increase the potential risk for infectious diseases transmission due to emerging countries recently challenged public health systems still devoted to endemic diseases issues associated to older policy. ${ }^{1}$

International travelers from emerging countries, like Brazil seems to be different to most country people with distinct social status and better health, shown by travel expenditure and travel insurance claims (Fig. 1C and D), corroborating to the "healthy immigrant effect".

Imported infectious diseases represent a new problem for these international travelers, where we see outbreaks caused by people visiting endemic or risky areas, including developed countries, and bring back previously controlled diseases like measles and mumps in Brazil - 2014/2015

The infectious disease control imposed by some nations, due to increased travel, leads to rethinking public health as a larger phenomenon. The current models of border surveillance, either by entry visa, limited length of stay or mandatory travel insurance (Schengen Convention), do not seem as effective in preventing the migration of infectious diseases transported both by foreign visitors or returning travelers. As an example, the recent Zika Virus epidemic in Brazil and fast worldwide spread, possibly a large-scale pandemic, promoted a global mobilization to control and study a new emerg ing disease, ${ }^{4}$ denoting the discussion of an important topic: infectious diseases are no longer limited to governmental borders or poor nations, they are a worldwide problem, especially the neglected ones.

Emerging countries with recently established public health systems are exquisitely exposed to new diseases outbreaks due to the recent increasing international travel, requiring more preventive measures both for border surveillance or control of their returning travelers, in a challenge for their endemic diseases dedicated systems. The full implementation of WHO's 2005 International Health Regulations, which includes the International Certificate of Vaccination and Prophylaxis, is mainly oriented to developed countries. Revision of these Regulations is required both to include this newcomer emerging systems but also vaccinepreventable diseases transferred from developed countries. ${ }^{5}$ Travel Insurance should be an important tool due to the possibility of travelers to receive medical treatment that would prevent bringing back infectious diseases to their home countries.

We believe that it is mandatory to create a unique global network in order to improve the notification of easily transmitted diseases and also unknown diseases, where everyone should adopt rigid protocols to provide information regarding new or current outbreaks. In addition, all data must be available for all nations, which could ultimately lead health policy makers around the world to get full access regarding all unified outbreak alerts. Probably, we could tackle H1N1, Ebola, and Zika virus epidemics more effectively and maybe researchers could gather more information to eventually help Health Authorities to prevent future epidemics, and speed up treatment of sick people. 

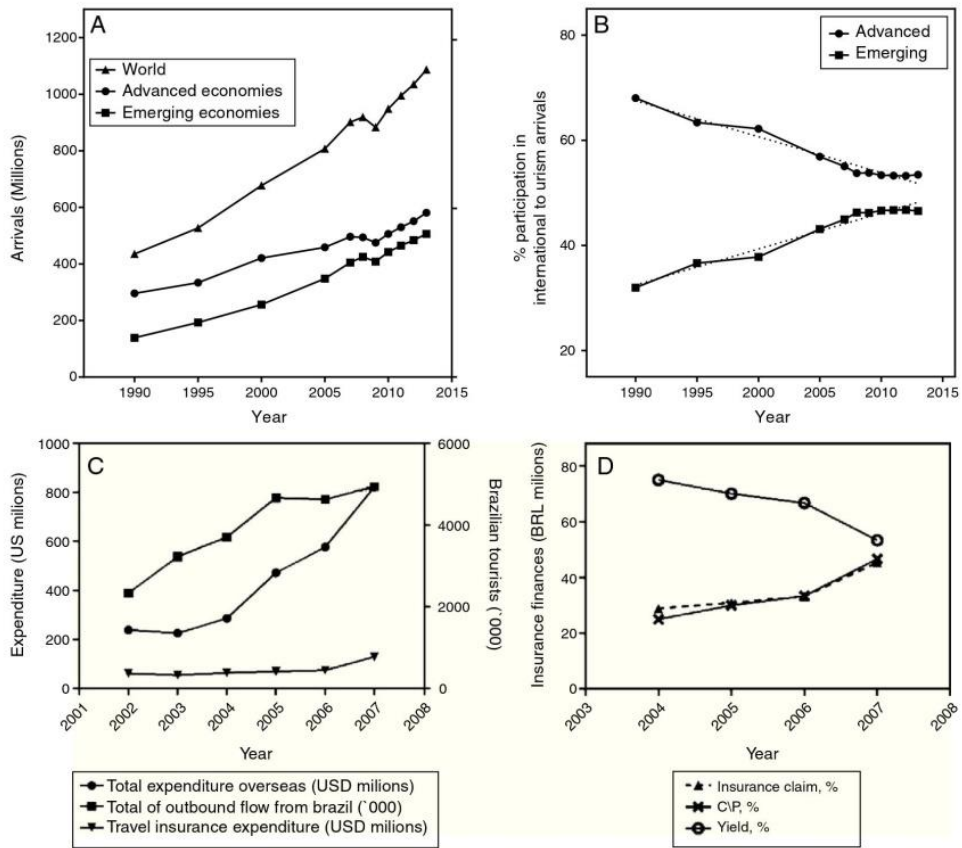

Year

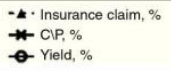

Fig. 1 - A - International tourism in the world (triangles)/advanced (dots) or emerging (squares) countries, expressed a millions of arrivals (closed symbols). B - Percentage of world arrivals from each origin. Dotted lines represent the $95 \%$ confidence interval of regression lines. $p$-Values are the comparison of slopes between regressions. $C$ - Expenditure of Brazilian tourists abroad. D - Travel insurance indexes of Brazilian tourists abroad. Straight lines represent regression lines and correspondent interrupted lines represent the $95 \%$ confidence intervals.

\section{Conflicts of interest}

The authors declare no conflicts of interest.

\section{Acknowledgments}

The authors wish to acknowledge the assistance from Instituto de Medicina Tropical de São Paulo-USP, LIM - 49/LIM -

52-HCFMUSP, FAPESP and CAPES.

\section{REFERENCES}

1. Hunter P. Tropical diseases and the poor: neglected tropical diseases are a public health problem for developing and developed countries alike. EMBO Rep. 2014;15:347-50.
2. Kwak K. An evaluation of the healthy immigrant effect with adolescents in Catar examinations of gender and length of adolescents in Canada: examinations of

3. Nali LH, da S, Fujita DM, et al. Potential measles transmission risk in mass gatherings: are we safe for the Olympic games-Rio
ression 2016:23.

4. De Cock KM, Simone PM, Davison V, Slutsker L. The new globa health. Emerg Infect Dis. 2013;19:1192-7.

5. Steffen R, Behrens RH, Hill DR, Greenaway C, Leder K.

Vaccine-preventable travel health risks: what is the evidence what are the gaps? J Travel Med. 2015;1:1-12.

Dennis Minoru Fujita ${ }^{a, *}$, Luiz Henrique da Silva Nali ${ }^{b}$ Paulo Roberto Urbano ${ }^{\mathrm{b}}$, Débora Maringoni Soeiro ${ }^{\mathrm{a}}$ Heitor Franco de Andrade Jr. 
a Universidade de São Paulo (USP), Instituto de Medicina Tropical de São Paulo, Laboratório de Protozoologia, São Paulo, SP, Brazil

b Universidade de São Paulo (USP), Instituto de Medicina Tropical de São Paulo, Laboratório de Virologia, São Paulo, SP, Brazil

\section{*Corresponding author.}

E-mail address: dmfujita@usp.br (D.M. Fujita).
Received 23 May 2016

Accepted 27 June 2016

Available online 26 July 2016

1413-8670/๑ 2016 Sociedade Brasileira de Infectologia. Published by Elsevier Editora Ltda. This is an open acces article under the CC BY-NC-ND license (http://

creativecommons.org/licenses/by-nc-nd/4.0/)

http://dx.doi.org/10.1016/j.bjid.2016.06.003 
LETTER TO THE EDITOR

Entry routes for Zika virus in Brazil after 2014 world cup: New possibilities

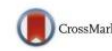

Dear Editor,

In the beginning of 2015 , several cases of Dengue and Chikungunya virus infections were reported in Brazil [1]. Dengue epidemics are located in the states of São Paulo $(637,029$ confirmed cases), Minas Gerais $(166,360$ confirme cases), Goiás (121,501 confirmed cases), Pernambuco (68,510 confirmed cases), Ceará (59,074 confirmed cases), Rio de Janeiro (49,480 confirmed cases), Paraná $(46,694$ confirmed cases), Bahia (42,476 confirmed cases), Rio Grande do Norte (21,194 confirmed cases), Mato Grosso do Sul (18,663 confirmed cases), Paraiba (18,018 confirmed cases), Espírito Santo $(16,477$ confirmed cases), Alagoas (13,846 confirmed cases) e Mato Grosso (13,700 confirmed cases). For Chikungunya virus infection, the state of Bahia appears as first in number of confirmed cases (7820), followed by Amapá (1070) and Federal District (194).

Zika virus infections presented clinical pictures very similar to dengue, and the number of cases reported officially are low, provided by problems in detection as it oc curs in a dengue virus area and co -infection of these viruses is not uncommon [2]. The strongest hypothesis of the introduction of Zika virus in Brazil has bought by African travelers during the 2014 World Cup has virus transmission by asymptomatic patients, aside to significant increase of
$132 \%$ in international tourists flow (June/2014 compared to June/2013) to the country.

But the circulating virus in Brazil was identified as Asian genotype through phylogenetic analyzes of the envelope region in the two cases from the state of Bahia, the area with highest number of confirmed cases [3], and due to Zika genotype found, alternative routes for new external entrance must be studied, allowing better comprehension entrance must be studied, allowing bet
of the virus circulation in the country.

We checked the numbers of travelers received in Brazil (Table 1) from endemic regions of Zika Virus (Africa, Asia Pacific Islands and Chile - Fig. 1) looking for those presenting a greater potential for carrying the Asian Zika virus strain. We found higher numbers of Asians tourists in this strain. We found higher numbers of Asians tourists in this
period as compared to few Africans by several states, as well as, the proximity of the country to Chile, which in the period surrounding the 2014 World Cup presented confirmed case of Zika virus from Easter Island, whose phylogeny was detected as Asian strain [4]. Domestic stream is another plausible possibility because the host stream is another plausible possibility because the host
cities of the games were located in several states, requiring cities of the games were located in several states, requiring
the movement of foreign and domestic travelers between these locations (São Paulo - SP, Rio de Janeiro - RJ, Salvador - BA Christmas - RN, Cuiaba - MT, Belo Horizonte MG, Fortaleza - CE, Recife - PE, Manaus - AM, Brasília DF, Porto Alegre - RS and Curitiba - PR).

The development of new studies becomes necessary to provide more control and supervision of borders due to exponential increase of foreign travelers to the country. The actual scenario of Zika Virus outbreak in Brazil and the detection of its entry route and spread in the country suggest new measures of public health for travelers especially by the proximity of Olympic Games that will be host in Rio de Janeiro in 2016.

\section{Conflict of interest}

The authors declare that they have no conflicts of interest. 


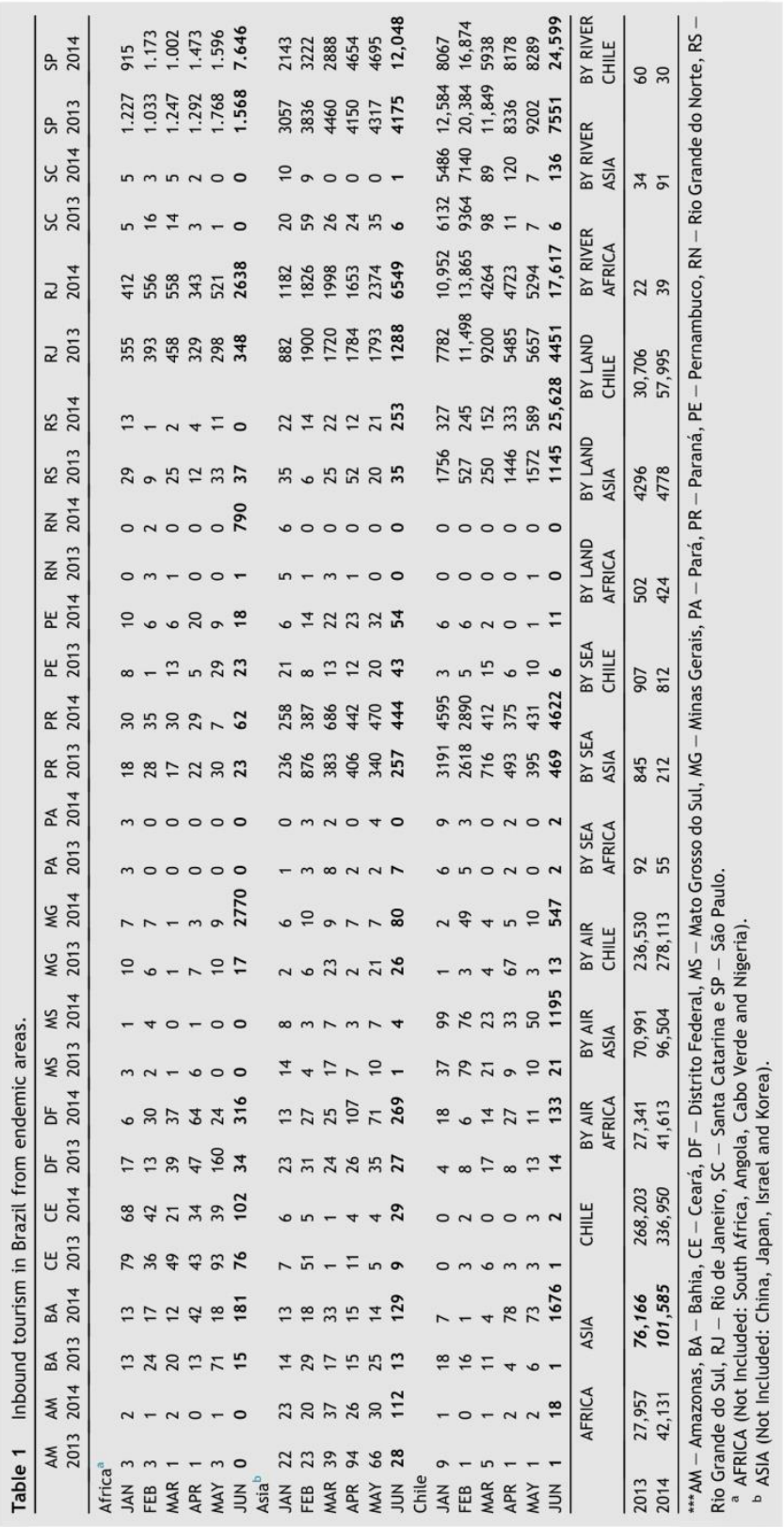




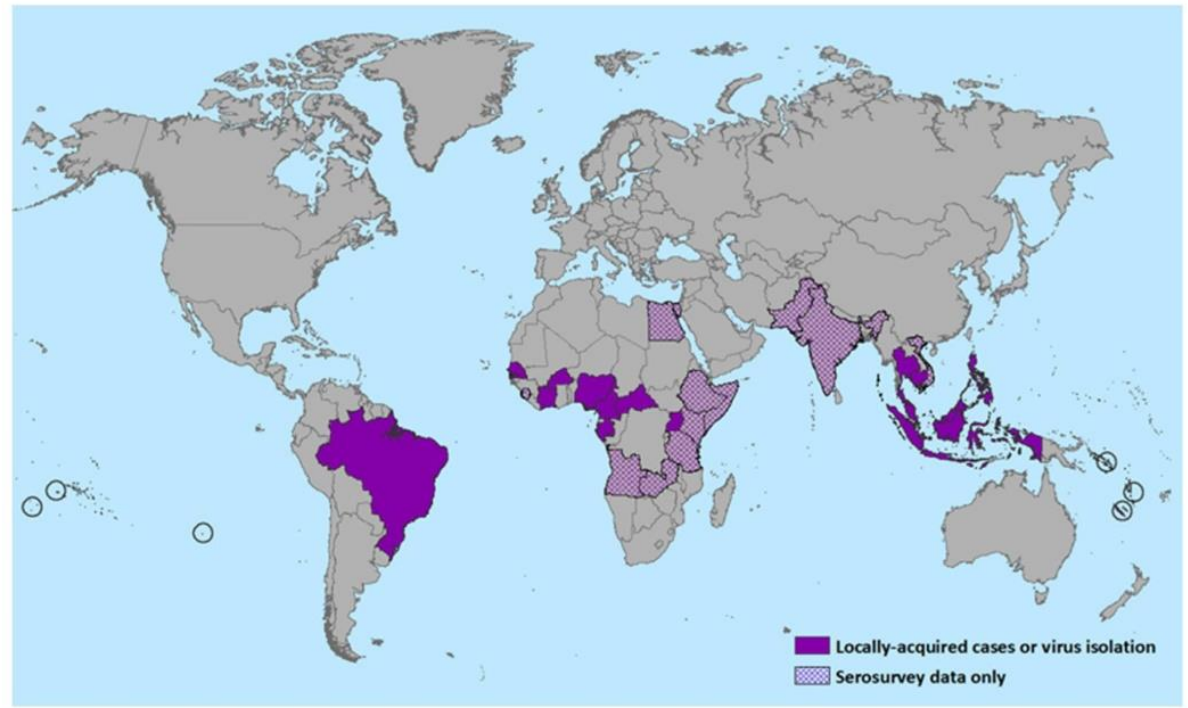

Figure 1 CDC - Countries that have past or current evidence of Zika virus transmission (as of May 2015) - http://www.cdc.gov/ zika/geo/index.html.

\section{Acknowledgments}

The authors wish to acknowledge the critical review of Prof. Heitor Franco de Andrade $\mathrm{Jr}$, besides to the assistance from Instituto de Medicina Tropical de São Paulo - USP, LIM - 49/LIM - 52 - HCFMUSP and CAPES.

\section{References}

[1] Ministério da Saúde, Secretaria de Vigilância em Saúde. Mon itoramento dos casos de dengue e febre de chikungunya até a Semana Epidemiológica 30, 2015. Bol Epidemiológico 2015; 46(24). Avaliable from, http://portalsaude.saude.gov.br/ images/pdf/2015/setembro/03/2015-029-SE-30.pdf.

2] Dupont-Rouzeyrol M, O'Connor O, Calvez E, Daurès $M$, John $M$, Grangeon JP, et al. Co-infection with zika and dengue viruses in 2 patients, New Caledonia, 2014. Emerg Infect Dis $2015 \mathrm{Feb}$ 21(2):381-2. http://dx.doi.org/10.3201/eid2102.141553. [3] Zanluca C, de Melo VC, Mosimann AL, dos Santos GI, dos
Santos CN, Luz K. First report of autochthonous transmission of
Zika virus in Brazil. Mem Inst Oswaldo Cruz 2015 Jun;110(4): 569-72. http://dx.doi.org/10.1590/0074-02760150192 [Epub 2015 Jun 9].

[4] PAHO. Epidemiological Alert: zika virus infection. May 7, 2015 Available from, http://www.paho.org/hq/index.php?option= Available from, http: $/ /$ www. paho.org $/ \mathrm{hq} /$ index.php?option=
com_docman\&task $=$ doc download\&t temid $=$ \&gid $=30075 \&$ la com_coch

Felipe Scassi Salvador Dennis Minoru Fujita* Instituto de Medicina Tropical de São Paulo, USP, São Paulo, Brazil

*Corresponding author. Av. Dr. Enéas Carvalho de Aguiar $470-1^{\circ}$ andar, CEP: 05403-000, São Paulo, Brazil. Tel.: +551130617004 E-mail address: dmfujita@usp.br (D.M. Fujita) 7 October 2015 
Perspective

\section{Potential measles transmission risk in mass gatherings: Are we safe for the Olympic games-Rio 2016?}

5 Luiz Henrique da Silva Nali, MSc ${ }^{1, *}$, Dennis Minoru Fujita, MSc ${ }^{2}$, Felipe Scassi Salvador ${ }^{1}$, Maria Cristina Domingues da Silva Fink, PhD ${ }^{1}$, Heitor Franco de Andrade Jr, PhD, MD², Cláudio Sérgio Pannuti, PhD, MD', Expedito José de Albuquerque Luna, PhD, MD

${ }^{1}$ Laboratório de Virologia do Instituto de Medicina Tropical da Universidade de São Paulo, ${ }^{2}$ Laboratório de Protozoologia do Instituto de Medicina Tropical da Universidade de São Paulo and ${ }^{3}$ Laboratório de Epidemiologia do Instituto de 10 Medicina Tropical da Universidade de São Paulo

*To whom correspondence should be addressed. Av. Dr. Enéas Carvalho de Aguiar, $470-2^{\circ}$ andar, CEP 05403-000, São Paulo, Brazil. Tel: +551130618649, Email: luiznali@usp.br

\section{Background}

The measles virus, genus Morbillivirus of the Paramyxoviridae 15 family, only infects humans. Measles is transmitted by droplets when the infected individual is coughing or sneezing. It is highly infectious ( $\mathrm{R} 0=15-20$ in a completely susceptible population), especially in closed environments such as shopping malls, schools and other confined places. Infected individuals can shed the virus

20 up to 4 days before the appearance of their symptoms and up to 4 days after the onset of symptoms. ${ }^{2}$ Also, its RNA is still detected in biological samples for many weeks. ${ }^{3}$ Measles is characterized by its high infectivity. The initial clinical manifestations include runny nose, cough, red and watery eyes and small white spots in-

25 side the cheeks. After several days, a maculo-papular exanthema erupts ${ }^{4}$ Measles was controlled in some regions, including Brazil. Recently, some outbreaks were reported in the country in the past few years and may represent a risk for transmission during mass gathering events, such as the Olympic Games. For that reason,

30 the aim of this article is to discuss the potential risk for Measles transmission in the country during the Olympic Games and also preventive measures in order to avoid other outbreaks.

\section{Measles global epidemiology}

The number of suspected and confirmed measles cases in 2015 re35 ported by $\mathrm{WHO}^{5}$ indicates a frame, in which the African Region presents the highest number of confirmed cases, whereas Region of Americas presents the lowest: African Region (54374 suspect/ 35557 confirmed), Region of the Americas (13083 suspect/366 confirmed), Eastern Mediterranean Region (26178 suspect/

4011610 confirmed), European Region (6642 suspect/6023 confirmed), South-East Asia Region (79713 suspect/67233 confirmed) and Western Pacific Region (120319 suspect/61493 confirmed). This represents a total of 300.309 suspect cases and 182.282 confirmed cases in the world until October 2015.

WHO indicates that from June 2014 to June 2015 in the 4 European Continent, there were more than 4000 cases reported in 30 countries, of those, Germany reported the highest number of cases $(58.2 \%)$, followed by Austria, Belarus, Lithuania, Denmark, Norway, UK, France, Sweden and Belgium. ${ }^{6}$

In the USA, ${ }^{7}$ touristic destination most sought (2014: $n=2.2650$ million) by Brazilian travellers, ${ }^{8}$ there were 23 outbreaks $(n=64$ cases), only in 2014. From January to September 2015, there were 189 confirmed cases in 24 states; of those, 117 cases $(62 \%$ were in the state of California. Most of these cases were associated to foreign travellers that came to the USA from Europe, ${ }^{9} 55$ demonstrating how infected travellers can contribute for triggering an outbreak in susceptible areas. This is also observed in other situations, such as in China during the Chinese New Year, many cases of Measles are reported very frequently in distinct regions; this increase during that period indicates that mass gatherings in 60 some places may facilitates viral dissemination. ${ }^{10}$

The global current frame of measles ${ }^{11}$ indicates outbreaks in the Democratic Republic of Congo, Guinea, Sudan, Australia, Mali, Algeria, Chile, Peru, Cameroon, Malaysia and Taiwan. Also, according to the data presented recently (February 2016) 65 by WHO, it report that Measles cases distribution per month increased significantly in the past 2 years in South East Asia Regions and countries from the Western pacific Region. ${ }^{12}$

Measles in Brazil: Are there risks of transmission during the Olympics?

According to Sao Paulo Health Secretariat, ${ }^{13}$ the vaccinatio coverage was estimated to be higher than $90 \%$ in 1-year-old 
children in Sao Paulo State during the period of 1993-1996, culminating in a significant decrease of the incidence due to Measles. This large vaccination coverage was due to routine vaccination applied by primary care units, where the population

5 seeks vaccination, and national vaccination campaigns, planned for every 5 years in Brazil, that are applied for specific target groups (children aged 1-12 years old), which drastically reduced the number of confirmed autochthonous cases in the country since 2000 , a year in which just 29 cases were reported in the

10 entire country. ${ }^{14}$ Autochthonous measles transmission was considered interrupted in Brazil, as well as in all other countries of the American Continent since 2000. Unfortunately, in the past 15 years, Brazil still presented some outbreaks mostly in the Northeast Region. The largest one was in 2014, when the

15 Ministry of Health reported 730 cases in the country, of them 696 occurred in the Ceará State. Also, an important event occurred that time, the 2014 Football World Cup, with 169.325 international travellers and 194.117 domestic travellers, ${ }^{15}$ and Ceará State received 6 of 64 matches of the event. Although the

20 investigation did not find the index case in Pernambuco's outbreak, it is noteworthy to point that it begun a week after the 'Carnival' festivities that attract yearly thousands of domestic and foreign tourists to the state. ${ }^{16}$ In this region, the affected adult population who were vaccinated only during childhood

25 might had been at risk due to low vaccine coverage and waning of the protection induced by the vaccine, probably repeating a known framework. ${ }^{17}$

Unfortunately, due to many facts like low vaccination coverage, socioeconomic conditions of some regions and the increase

30 of travellers, the virus had conditions to spread in some areas that were previously considered safe for any traveller.

Cases of measles transmission in domestic flight have also been reported in the literature demonstrating that the virus may be easily transmitted in confined places to susceptible

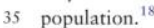

Measles in Brazil was considered controlled until 2012, presenting an increase in 2013 ( $n=200$ cases). The first regional alert was in Pernambuco (2013: 27 and 2014: 197 confirmed cases) and a considerable outbreak in the state of Ceará present-

40 ing $n=696$ ( $95.3 \%$ of the total cases in the country). In 2015 , we could observe a distinct scenario with an apparent decrease with $n=164$, until October, ${ }^{19}$ ending in September 2015. The rapid spread through Northeast region was due to the apparent low vaccination coverage ${ }^{20}$ indicating children below 1 year, a

45 population not included in target group, as a considerable number of infected subjects $(28.6 \%)$, followed by adults $(20 / 29$ years: $26.8 \%$ ) and teens ( $15 / 19$ years: $10.4 \%$ ). Of these, $89 \%$ had not been vaccinated for Measles.

The Southeast region had lower number of cases with $0.4 \%$

50 ( $n=3$ confirmed cases) in Rio de Janeiro and $0.95 \%$ ( $n=7$ confirmed cases) in Sao Paulo. In both states, Brazilian travellers had visited endemic regions importing the virus. We emphasize that the issue of limited failures in coverage can be observed with the appearance of outbreaks of mumps in 2015 at Rio de

55 Janeiro $n=568$ confirmed cases $^{21}$ and Sao Paulo $n=118$ confirmed cases. $^{2}$

The routine vaccination with Measles, Mumps and Rubella (MMR) establish the target group of women in reproductive age and children in primary care units, ${ }^{20}$ and the vaccination strategies occurred since 1992 had focused only in childhood 60 (1-12 years old), followed by routine vaccination and follow-up campaigns (age group 1-4 years) every 5 years. ${ }^{23}$ A national campaign with MMR was performed in 2008 to reach the goa to the elimination of Rubella and the Congenital Rubella Syndrome mainly in adulthood. ${ }^{24}$ Brazil has had no reports of 65 Rubella in the past 5 years, ${ }^{25}$ but the reemergence of measles and mumps with significant number of cases among 20-29 years subjects demonstrates the need for booster vaccination.

The adults can receive the vaccination free of charge, and the technical information is available including for travellers, but an 70 effective campaign to clarify and elucidate the population is mandatory to prevent situations like Ceará's outbreak. ${ }^{26}$

Developed countries face an issue regarding to parents behaviours in raising their children, due to rumors regarding to adverse events arising from vaccination, they stopped to vacci- 75 nate their children, ${ }^{27}$ this represent a major problem for strategies for controlling highly contagious diseases in emergen countries that had the disease in a relative controlled framework, like Brazil.

The fast spread of measles in Northeast Region is probably a 80 result of disqualification of the issue by the local governments (Ceará and Pernambuco), which led to a delay in public health response, and eventually to the infection of adults who were not vaccinated and then, the spread of the virus to their children. ${ }^{20}$ The resurgence of measles in 2014 , as a limited out- 8.5 break in Brazil, is also correlated with increasing tourists' inbound flow to the country, as well as travel by Brazilian abroad to endemic areas. ${ }^{16}$

Considering all previous data, the Olympic Games present favourable setting for measles transmission for susceptible popu- 90 lation due to mass gatherings with people shedding the virus in places that are often confined, ${ }^{28}$ like restaurants, airports, public transports, malls and also areas of competition. The Brazilian Ministry of Tourism estimates that 350000 to 500000 foreig travellers will come to the event, ${ }^{29}$ including people from areas 95 with recent outbreaks like China, Germany and other countries.

\section{Preventive measures to be taken in order to} avoid measles transmission during the Olympics

In order to prevent a measles outbreak in the country during the 2016 Olympic Games, it would require vaccination of all tour- 100 ism professionals and staff groups that will work directly and in directly with the event, which includes airship crews, hotel staff and restaurants employees, securities and health professionals. Orientation of medical community for fast diagnosis of disease is also important to avoid the rapid spread of the virus like the 105 one occurred in northeastern region in 2014.

Awareness of the Health Ministries regarding of preventive measures during mass gatherings events world-wide is a special concern, once events like these represent a special issue due its conditions for easily transmission diseases, such as measles, to 110 be imported and domestic traffic enables its wide dissemination. In addition, Brazilian travellers should seek for information regarding disease transmissions risks during a trip. There are at least 132 Travel Medicine centres available to the population, in most of them, the vaccination is free of charge, this could poten- 11 tially reduce inbound transmission during any trip, including 
Measles transmission during the Olympic Games. Foreign travellers should also vaccinate themselves in order to avoid importing measles to Brazil.

Finally, a disease with simple control such as measles might be5 come a large-scale epidemic in the country if there is no conscious planning of public health policies to prevent such situations.

\section{Acknowledgements}

The authors wish to acknowledge the assistance from Instituto de Medicina Tropical de São Paulo, USP, LIM-49/LIM-52-HCFMUSP,

10 FAPESP and CAPES.

\section{Conflict of interest:}

\section{References}

1. Monto AS. Interrupting the transmission of respiratory tract infections: theory and practice. Clin Infect Dis 1999; 28(2):200-4.

15 2. WHO. Measles 2016 [2016 March 31]. Available from: http://www. whoint/mediacentre/factsheets/fs286/en/ (31 March 2016, date last accessed).

3. Griffin D. Measles Virus Field's Virology. New York: Lippincott Williams \& Wilkins, 2007, pp. 1552-85.

20 4. WHO. Health Topics - Measles 2015 [cited 2015 October 19] Available from: www.who.int/topics/measles/en/ (19 October 2015,

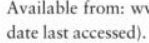

5. WHO. Reported Measles Cases by WHO region 2014, 2015, as of 05 October 20152015 [cited 2015 October 19]. Available from:

hrtp://www.who.int/immunization/monitoring_surveillance/burden/ $\mathrm{vpd} /$ /surveillance_type/active/measlesregionalsummary.pdf?ua $=1(19$ October 2015, date last accessed).

6. WHO. Reported measles cases and incidence rates by WHO member states 2013, 2014 as of 11 February 20152015 [cited 2015 October

30 19]. Available from: http://www.who.int/immunization/monitoring surveillance/burden/vpd/surveillance_type/active/measlesreportedcases bycountry.pdf (19 October 2015, date last accessed).

7. CDC. Cases and outbreaks. CDC Internet]. 2015 [cited 2015 October 19]. Available from: http://www.cdc.gov/measles/cases-out

35 breaks.html: CDC; 2015 [cited 2015 October 19]. Available from: http://www.cdc.gov/measles/cases-outbreaks.html (19 October 2015, date last accessed)

8. Turismo Md. Estatisticas Básicas do Turismo 2015 [cited 2015 August 12]. Available from: http://www.dadosefatos.turismo.gov.br/

40 dadosefatos/estatisticas_indicadores/estatisticas_basicas_turismo/ (12 August 2015, date last accessed).

9. Halsey NA, Salmon DA. Measles at Disneyland, a problem for all ages. Ann Int Med. 2015; 162(9):655-6.

10. Hu X et al. Gaps in the 2010 measles SIA coverage among migrant

45 children in Beijing: evidence from a parental survey. Vaccine. 2012; 30(39):5721-5.

11. ECDC. Communicable disease threats report: Week 25-31 January 20152015 [cited 2015 February 07]. Available from: http://www.ecdc. 20152015 [cited 2015 February 07 ]. Available from: http://www.ecdc.
europa.eu/en/publications/Publications/communicable-disease-threatseuropa.eu/en/publications/Publications/communicable-disease-thre
report-31-jan-2015.pdf (07 February 2015, date last accessed).

report-31-jan-2015.pdf (07 February 2015, date last accessed).
12. WHO. Measles Case Distribution by Month and WHO Regions, 2008-2015. 2015

13. CVE. Plano Nacional de Erradicação do Sarampo São Paulo: Coordenação dos Institutos de Pesquisa; 1999 [cited 2015 december
16]. Available from: http://www.cve.saude.sp.gov.br/htm/resp/ 55 Planosar.htm (16 December 2015, date last accessed).

14. CVE. Progresso na Erradicação do Sarampo nas Américas São Paulo Coordenação dos Institutos de Pesquisa; 1999 [cited 2015 december 16]. Available from: http://www.cve.saude.sp.gov.br/htm/resp/semi 16]. Available from: http://www.cve.saude.sp.gov.br/htm/resp/semi-
sp22.htm (16 December 2015, date last accessed).

15. Ceará GdEd. Número de estrangeiros cresceu quase $650 \%$ se comparado com junho de 2013; impacto na economia superou RS 1,6 bilhāo Ceará2015 [cited 2015 December 16]. Available from: http:// www.setur.ce.gov.br/noticias/fluxo-turistico-para-a-copa-superaexpectativas/?searchterm $=$ copa\%20turistas $\quad$ (16 December 2015,65 date last accessed).

16. Leite RD et al. Measles Reemergence in Ceara, Northeast Brazil, 15 Years after Elimination. Emerg Infect Dis. 2015; 21(9):1681-3.

17. Pannuti CS et al. Identification of primary and secondary measles vaccine failures by measurement of immunoglobulin G avidity in 70 measles cases during the 1997 Sao Paulo epidemic. Clinical and diag. nostic laboratory immunology. 2004; 11(1):119-22.

18. de Barros FR et al. Measles transmission during commercial air travel in Brazil. Journal of clinical virology : the official publication of the Pan American Society for Clinical Virology. 2006; 36(3):235-6.

19. Ceará SdSd. Boletim Epidemiológico Sarampo, 31de dezembro de 2014. 2014 [cited 2015 February 15]. Available from: http://www. saude.ce.gov.br/index.php/boletins (15 February 2015, date last accessed).

20. Rocha $\mathrm{HA}$ et al. Factors associated with non-vaccination against 80 measles in northeastern Brazil: Clues about causes of the 2015 outbreak. Vaccine. 2015;33(38):4969-74

21. Fiocruz. Nota Técnica de Caxumba. 2015. [cited 2015 December 16]. Available from: https://www.bio.fiocruz.br/index.php/noticias/ 1042-nota-tecnica-de-caxumba (21 January 2016, date last 85 accessed).

22. CVE C-CdVEPEC. CAXUMBA: Distribuição de surtos, casos e óbitos, segundo ano de início dos sintomas e faixa etária, Estado de São Paulo, 2001 a 2016. 2015.

23. Freitas DR et al. Investigation of an outbreak of hypersensitivity-type 90 reactions during the 2004 national measles-mumps-rubella vaccination campaign in Brazil. Vaccine. 2013;31(6):950-4.

24. Domingues $\mathrm{CM}$ et al. National immunization program: vaccination, compliance and pharmacovigilance. Revista do Instituto de Medicina Tropical de Sao Paulo. 2012; 54 Suppl 18:S22-7.

25. Health BMo. Casos Confirmados de Rubéola. Brasil, Grandes Regióes e Unidades Federadas. 1997 a 2015. 2015.

26. Saúde. Md. Portal Saúde - SUS. Vacinaçāo 2015 [cited 2015 October 15]. Available from: http://portalsaude.saude.gov.br/index.php/o ministerio/principa//leia-mais-o-ministerio/424-secretaria-svs/vigilan 100 cia-de-a-a-z/sarampo/11-sarampo/10779-vacina-sarampo (15 October 2015, date last accessed).

27. Kennedy AM et al. Vaccine beliefs of parents who oppose compusory vaccination. Public health reports. 2005; 120(3):252-8.

28. Johansson A et al. Crowd and environmental management during 105 mass gatherings. The Lancet Infectious diseases. 2012; 12(2):150-6.

29. Brazil. Brasil 2016 - Official Federal Government Portal About The 2016 OlympicAnd Paralympic Games Brazil: Brazilian Federal Government 2016 [2016 March 31]. Available from: http://www.brasil2016.gov.br/pt-br/pais-sede/melhorias-nos-servi 11 cos-e-na-infraestrutura-turistica (31 March 2016, date last accessed) 
Perspective

\section{Preventive measures for "Pet Friendly" lodging facilities: association of Leishmaniasis expansion route in São Paulo and preventive measures for regional animals displacement}

Camila Aparecida de Carvalho ${ }^{1 *}$, Dennis Minoru Fujita ${ }^{1}$, Luiz Henrique da Silva Nali ${ }^{1}$, Heitor Franco de Andrade Júnior ${ }^{1}$, and Roberto Mitsuyoshi Hiramoto ${ }^{2}$

'Instituto de Medicina Tropical de São Paulo - USP, São Paulo, Brazil and ²Departamento de Parasitologia - Laboratório de Parasitologia -Instituto Adolfo Lutz, São Paulo, Brazil

"To whom correspondence should be addressed. Av. Dr. Enéas Carvalho de Aguiar, 470 - 1' andar, CEP: 05403-000 - São Paulo, Brazil. Phone: -551130617004, Email: camilacarvalho@usp.br

Submitted 9 February 2017; revised 17 March 2017; Accepted 23 March 2017

Travel medicine has been facing new challenges in public health due to the increase in international travel $(2015-n=1.2$ billion) and the inclusion of pets in this framework can intensify the transmission of many zoonotic diseases. Pet facilities are increasing significantly in many countries, e.g. the American Pet Products Association-APPA, estimated a revenue of \$62.75 billion, an increase of $4 \%$ over $2015 .{ }^{1}$ Many pets are imported from other countries, as an example, in UK, 164836 dogs were introduced following the international rules in recent years, with the importation of 65080 dogs importation from 128 countries only in 2015 . $^{2}$

For this reason, some countries implemented mandatory cross border measures based on vaccination certificates, particularly for rabies and other zoonotic diseases. ${ }^{3}$ However, the companion animals domestic displacement between cities made by land in a short distance represents a high risk due to no existence of specific surveillance for this activity, providing a favourable environment for emerging and re-emerging zoonotic diseases, ${ }^{4}$ because pets travelling are potentially exposed to new pathogens at tourism destinies, transporting those diseases at the home return. This risk is under the interpretative model of One Health, ${ }^{5}$ a concept which recognizes that the health of humans are connected to the health of animals and the environment in the world as a whole.

In Brazil, there are $\sim 52.2$ millions of dogs and 22.1 millions of cats in households, the high number of beloved companion animals represent a potential pet market that include tourism travel and other services, some of them must have specific rules.
Unfortunately, $\sim 25 \%$ of these animals were not vaccinated for Rabies in the last year in Brazil, even with annual campaign and free vaccine distribution in main capitals. ${ }^{6}$ Considering the potential increase in regional pet travel, this neglecting behaviour of companion animals owners with a controllable known disease could be a risk for other zoonoses, as Visceral Leishmaniasis (VL) in Brazil.

A recent study in Brazil reported that only $24 \%$ of pet owners bring their companion animals for regular consultation an only $75 \%$ will seek a veterinarian if the pet presents a serious health problem, suggesting that preventive measures for infectious diseases or even vaccination could be an important neglected aspect. This problem demands a surveillance model for short travel of pets, but this goal may be not so simple to be executed.

In Brazil, hospitality companies look for attract this new group composed of companion animals and their owners, by using specific facilities identified as Pet Friendly establishments. The huge growth of travels requires the development of preventive measures to ensure a local safe displacement with the establishment of a surveillance system for infectious diseases that could alert this group for potential risks.

In a manner some diseases with this animal-human determinant are mapped in Brazil, but its conversion in information of public health protection should be not so fast than required, as the case of VL in the State of São Paulo, an zoonotic parasitic infection which in Brazil are caused by Leishmania infantum chagasi species. The disease is expanding in our country with an 
Table 1. Cities with confirmed dog infected by VL in neighbouring town

\begin{tabular}{|c|c|c|c|c|c|c|}
\hline \multirow[t]{2}{*}{ City } & \multirow[t]{2}{*}{ Pet friendly facilities } & \multicolumn{2}{|c|}{ Canine VL-2015 } & \multicolumn{2}{|c|}{ Human VL-2015 } & \multirow[t]{2}{*}{ Classification } \\
\hline & & Conf Cases & Death & Conf Cases & Death & \\
\hline Araçoiaba da Serra & 2 & 0 & 0 & 0 & 0 & Silent, non-receptive and vulnerable \\
\hline Aramina & 1 & 0 & 0 & 0 & 0 & Silent, non-receptive and not vulnerable \\
\hline Araras & 1 & 0 & 0 & 0 & 0 & Silent, non-receptive and vulnerable \\
\hline Atibaia & 1 & 0 & 0 & 0 & 0 & Silent, non-receptive and vulnerable \\
\hline Brotas & 6 & 0 & 0 & 0 & 0 & Silent, non-receptive and vulnerable \\
\hline Campos do Jordão & 2 & 0 & 0 & 0 & 0 & Silent, non-receptive and vulnerable \\
\hline Caraguatatuba & 2 & 0 & 0 & 0 & 0 & Silent, non-receptive and vulnerable \\
\hline Guarujá & 2 & 0 & 0 & 0 & 0 & Silent, non-receptive and vulnerable \\
\hline Illhabela & 3 & 0 & 0 & 0 & 0 & Silent, non-receptive and vulnerable \\
\hline Itapevi & 1 & 0 & 0 & 0 & 0 & Silent, non-receptive and vulnerable \\
\hline Mairiporã & 1 & 0 & 0 & 0 & 0 & Silent, non-receptive and vulnerable \\
\hline Monte Alegre do Sul & 2 & 0 & 0 & 0 & 0 & Silent, non-receptive and vulnerable \\
\hline Natividade da Serra & 1 & 0 & 0 & 0 & 0 & Silent, non-receptive and not vulnerable \\
\hline Peruibe & 1 & 0 & 0 & 0 & 0 & Silent, non-receptive and not vulnerable \\
\hline Piedade & 1 & 0 & 0 & 0 & 0 & Silent, non-receptive and vulnerable \\
\hline Ribeirāo Preto & 1 & 0 & 0 & 3 & 0 & Silent, non-receptive and vulnerable \\
\hline Santo Antônio do Pinhal & 2 & 0 & 0 & 0 & 0 & Silent, non-receptive and not vulnerable \\
\hline São Bento do Sapucaí & 1 & 0 & 0 & 0 & 0 & Silent, non-receptive and not vulnerable \\
\hline São José do Barreiro & 1 & 0 & 0 & 0 & 0 & Silent, non-receptive and vulnerable \\
\hline São Luís do Paraitinga & 1 & 0 & 0 & 0 & 0 & Silent, non-receptive and not vulnerable \\
\hline São Paulo & 9 & 0 & 0 & 17 & 0 & Silent, non-receptive and vulnerable \\
\hline São Sebastiāo & 5 & 0 & 0 & 0 & 0 & Silent, non-receptive and vulnerable \\
\hline Serra Negra & 3 & 0 & 0 & 0 & 0 & Silent, non-receptive and vulnerable \\
\hline Socorro & 5 & 0 & 0 & 0 & 0 & Silent, receptive and vulnerable \\
\hline Torrinha & 1 & 0 & 0 & 0 & 0 & Silent, non-receptive and vulnerable \\
\hline Ubatuba & 1 & 0 & 0 & 0 & 0 & Silent, non-receptive and vulnerable \\
\hline Total & 57 & 0 & 0 & 20 & 0 & \\
\hline
\end{tabular}

incidence of 3500 human cases/year and despite the major incidence of cases in the Northeast and North Brazilian Regions, the epidemic increase of $16 \%$ of human cases in 2015 in a previously free Southeast Region that now represents an important health problem."

The transmission cycle starts when the insect vector (Lutzomia longipalpis) ingests the parasite in host invertebrates (mammals' reservoir) and then infect humans at the time of the new blood meal. ${ }^{9}$ Among the main reservoirs of the VL, the domestic dog stands out in the disease dissemination due to its important role in the context of human relations.

The advance of VL in São Paulo's state occurs progressively (Cities with warnings for VL-n=123-76 Human and Canine/47 only Canine), with environmental limitation conditions, and in a susceptible canine population restricted by a geographical area with slow dispersal potential (migration of infected dogs between cities/vector existence). From 1999 to 2014, it was reported 5.798 suspected cases of VL in humans, which 2.467 were confirmed as autochthonous in 85 municipalities, with 214 deaths, resulting in a mortality rate of $8.7 \%$ (214/2.467), and the concentration of cases in the northwest region of the State. ${ }^{10}$

Concomitantly, the number of Pet Friendly facilities in Brazil increased to $n=174$, which $32.75 \%$ of these equipment are hosted in São Paulo's State $(n=57)$ distributed in 26 cities with potential for silent transmission of $\mathrm{VL}$. The hotels are located in areas with no canine confirmed cases, but three of them presents confirmed cases in bordering towns: São Paulo, the capital of
State, Araçoiaba da Serra and Ribeirão Preto. São Paulo and Ribeirão Preto may had confirmed cases in humans $(n=17)$ $n=3)$, but we may consider a direct risk $(n=10 / n=1)$ because the cases are autochthonous and apparently there is no vector to continue the transmission cycle from dogs to humans (Table 1). According to a recent study, ${ }^{11}$ six new cities are infected by VI each year in São Paulo State, and this unsupervised displacement of dogs can increase this progression.

Nevertheless, the Pet Friendly establishments can receive and host asymptomatic infected dogs from neighbouring towns with positive cases of $\mathrm{VL}$ and endemic regions (Figure 1), increasin the potential for transmission if we consider other routes, with non-vector mechanism, which might promote the dog-to-dog infection. ${ }^{12,13}$

For this hypothetical scenario, pets' domestic displacement suggests a susceptible condition for increasing the potential transmission of emerging and re-emerging diseases, as VL and other zoonotic protozoal parasites, including giardiasis, Chagas disease, toxoplasmosis and babesiosis, ${ }^{14}$ due to geographic barriers are not a limiting factor due to the potential reservoirs travel to endemic regions. It's a new traveller condition and behaviour which will affect other countries, including developed nations as USA there were 77.8 million $(>49 \%)$ million/dog and $85.8(>288.23 \%)$ million/cats as companion animals in 2015. ${ }^{15}$ And The European continent presents the phenomenon of companion animals and the importation of infectious diseases, with the displacement of $L$. infantum but the transmission is limited to canines. ${ }^{16}$ 

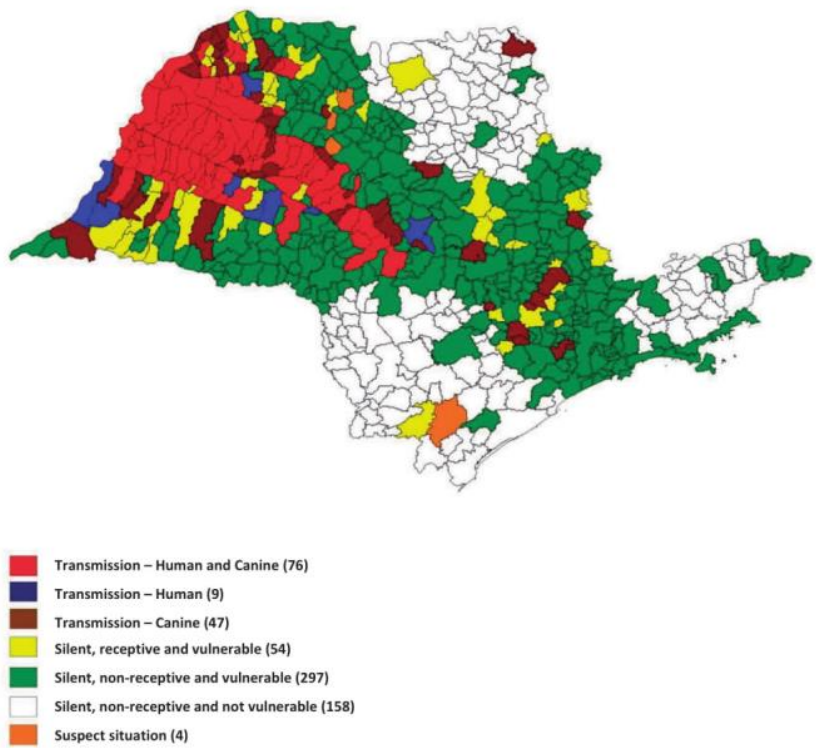

Figure 1. Map of epidemiological classification for VL in December 2014, State of Sảo Paulo/Ciaravolo RMC et al

The VL situation in São Paulo requires attention due to suspect deaths of human in the area of Barreira do João da Guarda-Cantagalo community (an important Favela of São Paulo Coast), located nearby the Enseada ( $2.2 \mathrm{~km}$ distance), one of the most popular beaches for travellers in Guaruja ( $n=2-$ Pet Friend Facilities), highlighting the disease progression in the area and the potential risk for short distance travellers. The first death occurred in 2016 august 28, childmale-age: 1 year and 7 months, followed 3 months later by the hospitalization of the older brother-age: 4 years, which died in November 21. The dog's family was detected positive for VL according to the local authorities. The samples of the first children were not collected due to his fast death being considered as a natural cause. The second death is in analysis for $\mathrm{VL}$ in the Centro Infantil Boldrini, a reference centre for VL diagnosis. ${ }^{17}$

The VL confirmation in Guarujá should disclosure a new progression movement, not being slow and progressive but randomized, because Guarujá City is a coast touristic destination with a considerable distance from the nearby city with confirmed canine transmission (Taboão da Serra-116 km distance), demonstrating that the increased displacement of people and animals can be a potential way to spread an infectious disease.

Other important considerations are the potential existence of a large group of infected dogs at this touristic area; the jump in transmission from canines to Humans due to the existence of L. longipalpis, the main vector for $\mathrm{VL}$, in the region ${ }^{11}$ and the potential increase in autochthonous human cases of VL in the next months at other cities of São Paulo.

To control this potential concern, the "Pet friendly facilities" will need a responsible veterinarian as mandatory and the study of this new modality of travel, because important questions raise as the real risk of transmission for pets, the adequate preventive measures to be taken in some places, infrastructure and requirements for the lodging facilities and security rating for VL transmission in hotels and other infectious diseases. The report of suspect cases should be available as soon as possible by local zoonosis control centres to assist the veterinarians in this protective action, and not 1 year later after the occurrence as the actual model.

However, until this mobilization occur, we need to star with reasonable preventive measures for travellers and their pet including a previous veterinarian consultation to check the current health condition of the pet as well as the potential risk and Canine's endemic diseases of the region to be visited, even in a short displacement. Routine vaccination for diseases such as Leptospirosis, Rabies, Lyme and other infectious diseases allied to a vaccination certificate may be a mandatory policy for the acceptance of the guests and the companion animals in a Pet Friendly Facility, Veterinarians can recommend other measures like the use of insect repellents for pets, and in extreme cases, to avoid risk areas, which will be responsible to improve this surveillance system including other methods for infectious disease control like test of animals and other techniques that insure this new segment of regional short distance travel. 


\section{Acknowledgements}

The authors wish to acknowledge the assistance from Instituto de Medicina Tropical de São Paulo-USP, LIM-49/LIM-52-HCFMUSP, Laboratório de Parasitologia-Instituto Adolfo Lutz, FAPESP and CAPES.

Conflict of interest: None declared.

\section{References}

1. APPA. Pet Care Industry Analysis 2016 - Cost \& Trends. https:/l www.franchisehelp.com/industry-reports/pet-care-industry-report' (15 August 2016, date last accessed).

2. Pet Travel The Kennel Club. http://www.thekennelclub.org.uk/ourresources/kennel-club-campaigns/pet-travel/ (15 August 2016, date last accessed).

3. Davidson RK, Robertson LJ. European pet travel: misleading information from veterinarians and government agencies. Zoonoses Public Heal 2012; 59: 575-83.

4. Meslin FX, Stohr K, Hevmann D. Public health implications of emerging zoonoses. Rev Sci Tech 2000; 19: 310-7.

5. Call for global surveillance of diseases of companion animals. Vet $\operatorname{Rec} 2012 ; 171: 519$.

6. Brasil. Pesquisa Nacional de Saúde. http://biblioteca.ibge.gov.br/visu alizacao/livros/liv94074.pdf (7 July 2016, date alst accessed).

7. Comac. Radar Pet. 2014. http://www.comacvet.org.br/nove imprensa/13/Primeira-pesquisa-Radar-Pet-avalia-com-profundi imprensa/13/Primeira-pesquisa-Radar-Pet-avalia-com-profundi dade-o-mercad

8. Brazil. Leishmaniose visceral-Casos confirmados notificados no Sistema de Informação de Agravos de Notificação-SINAN-São Paulo. Brazilian Ministry of Health. http://tabnet.datasus.gov.br/cgi/ tabcgi.exe? sinannet/cnv/leishvsp.def (1 August 2016, date last accessed).

9. Harhay MO, Olliaro PL, Costa DL, Costa CHN. Urban parasitology visceral leishmaniasis in Brazil. Trends Parasitol 2011; 27: 403-9.

10. Ciaravolo RM, de C, de Oliveira SS, Hiramoto RM et al. Epidemiological classification of cities according to the program of surveillance and control of visceral leishmaniasis in the state of Sä Paulo, updated in December 2014. BEPA, Bol Epidemiol Paul 2015 12: 9-22.

11. Oliveira AM, Vieira CP, Dibo MR, Guirado MM, Rodas LAC Chiaravalloti-Neto F. Dispersal of Lutzomyia longipalpis and expansion of canine and human visceral leishmaniasis in São Paulo State, Brazil. Acta Trop 2016; 164: 233-42.

12. Gomes de Oliveira V, Alves L, Da Silva Junior V. Transmission routes of visceral leishmaniasis in mammals. Cienc Rural 2015; 45: $1622-8$

13. Karkamo V, Kaistinen A, Näreaho A et al. The first report of autochthonous non-vector-borne transmission of canine leishmaniasis in the Nordic countries. Acta Vet Scand 2014; 56: 84

14. Esch KJ, Petersen CA. Transmission and epidemiology of zoonotic protozoal diseases of companion animals. Clin Microbiol Rev 2013, 26: 58-85.

15. APPA. Pet Industry Market Size \& Ownership Statistics. http:// www.americanpetproducts.org/press_industrytrends.asp (15 August 2016, date last accessed).

16. Maia C, Cardoso L. Spread of Leishmania infantum in Europe with dog travelling. Vet Parasitol 2015; 213: 2-11.

17. G1 Santos. Após morte de irmãos, profissionais têm capacitação sobre leishmaniose. Globo Network. 2016. http://g1.globo.com/sp/ santos-regiao/noticia/2016/12/apos-morte-de-irmaos-profissionaissantos-regiao/noticia/2016/12/apos-morte-de-irmaos-profissionais-
tem-capacitacao-sobre-leishmaniose.html (16 March 2017, date last accessed). 


$\begin{array}{llll}\text { POTENTIAL FACTORS THAT CONTRIBUTE IN } & \text { PARASITIC } & \text { DISEASES } \\ \text { TRANSMISSION: } \quad \text { SCHISTOSOMA } & \text { MANSONI } & \text { IN } & \text { CHAPADA } \\ \text { DIAMANTINA/BAHIA - BRAZIL - } 2017 & & & \end{array}$

The recent global climate changes developed new watershed scenarios in some regions worldwide with extreme rainfall in short periods, resulting in devastating flooding of areas, followed by prolonged droughts[1], compromising the systems of water supply, sanitation and hygiene of the cities[2], which might enable the reemergence of opportunistic diseases.

Natural disasters are usually proceeded by outbreaks implying into adopting the strategy of mobilization and specialized assistance for the elimination of the source, when it's possible, or reducing the transmission route[3].

The climate changes affect local ecosystems, altering their fragile balance, and may favor the entry of infectious diseases into receptive but non-active regions. Such changes reduce the natural barriers as the regular temperature in the seasons, rainfall index, among other natural factors that could prevent the establishment or even growth of an endemic in some regions[4].

A converging problem is the increase of ecotourism and adventure travel worldwide, especially in Brazil (Figure 1). The direct contact of travelers to natural areas may lead to an involuntary infection by these agents[5].

Following this idea, some opportunistic infectious diseases, especially those caused by parasites, despite the decreasing historical series (Table 1), present some peaks of seasonal incidence, as the recent outbreaks of Schistosomiasis in Chapada Diamantina National Park - Bahia, one of the most important destinations for adventure travel and ecotourism in Brazil.

Schistosomiasis is a parasite-related chronic inflammatory condition caused by trematodes parasites of the genus Schistosoma that can cause liver abnormalities and anemia. The S. mansoni is the only species of Schistosoma in the American continent, 6 in total - S. hematobium, S. japonicum, S. intercalatum, S. mekongi and S. malayensis.

In Brazil, Schistosomiasis mansoni is endemic in some regions of the country and considered a serious public health problem, whit a considerable number of deaths/year, a consequence of the inadequate conditions of hygiene and health in poverty locations.

The transmission cycle in urban areas involves the human who excretes parasite eggs through feces, and the aquatic snails of the genus Biomphalaria, which act as an intermediate host, that release infective larvae of S. mansoni in the contaminated water collections used by susceptible humans that acquire by the skin or mucous membranes in contact to this contaminated environment, generating a continuous process.

According to the World Health Organization[6], 66.5 million people were treated for schistosomiasis, but $\sim 218$ million people required preventive treatment for this infectious disease in 2015. 
The first outbreak of Schistosomiasis occurred in 2017/February[7], after a holiday trip (Brazilian Carnival) in Lençóis, the main city of Chapada Diamantina National Park. A group of 32 mountain bike riders and relatives were infected after swimming in a contaminated lagoon (stream of the Mosquito Waterfall), with the confirmed diagnose for Schistosoma mansoni obtained after 45 days in hometown (Montes Claros - MG State).

The main adventure activity was not the real cause or route for the infection, but a secondary leisure activity developed in this natural environment. The investigation of other leisure activities developed by adventure travelers in a natural area may be a recommended protocol for diagnosis. The city of Lençóis, which concentrates the main infrastructure and support services for adventure travelers, historically presented a low incidence of Schistosomiasis positive cases related to local population, but the unusual rainfall registered in February[8] may contributed to the waterfalls and lagoons contamination.

Another extreme precipitation occurred in May and June followed by a second Schistosomiasis' outbreak[7] in 2017/June ( $\mathrm{n}=105$ positive cases), after a large flooding period, with the interdiction of 2 new areas of water recreation (previously the Poção, and now the Poço Verde e Banho da Ponte, all located in the city of Lençóis).

In this context, the increase of leisure activities in natural areas, as the ecotourism, might be a considerable risk practice due to the direct contact of people with areas previously considered safe but now contaminated by pathogens that migrate to survive or emerge after the intense rainfalls or other natural disasters. These activities may accelerate the spread of an infectious disease in a region and even the exportation to other countries.

Due to the actually climate changes, other regions, including some areas of developed countries, present a favorable diseases network for some tropical and neglected parasitic diseases as Schistosomiasis.

The recent outbreak in France (Corsica) is an example of this problem[9]. The fast adaptation and transmission of Schistosomiasis occurred due to new conditions as the find of a new reservoir and the increase of temperatures in this region with a reduced winter (the low temperature in a regular season is a natural barrier to the persistence of the potential host), allied to the refugees migration or the possible importation by French citizens travelling from North Africa to Europe, resulting in an unexpected problem[10].

The recommendations for travelers to natural areas, specific for Schistosomiasis mansoni prevention, and visiting regions affected by flooding or other natural disasters, are to avoid water recreation activities, use of waterproof boots and other protective clothing and take special attention for personal cleanliness and good hygiene practices during the trip.

\section{References}

[1] J.H.P. de B. Salgueiro, S.M.G.L. Montenegro, E.J. de A. Pinto, B.B. da Silva, W.M. de Souza, L.M.M. de Oliveira, Influence of oceanic-atmospheric interactions on extreme events of daily rainfall in the Sub-basin 39 located in Northeastern Brazil, RBRH. 21 (2016) 685-693. doi:10.1590/2318- 
0331.011616023.

[2] W.S. Griffies, M. Richards, M. Chicarelli, A. Ernst, A. Harrell, D. Stites, C.E. Dunn, S. Nodwell, L. Dominelli, R. Holden, Health Care Infrastructure PostKatrina: Disaster Planning to Return Health Care Workers to Their Home Communities, Psychiatr. Serv. 61 (2010) 70-73. doi:10.1176/ps.2010.61.1.70.

[3] I.K. Kouadio, S. Aljunid, T. Kamigaki, K. Hammad, H. Oshitani, Infectious diseases following natural disasters: prevention and control measures, Expert Rev. Anti. Infect. Ther. 10 (2012) 95-104. doi:10.1586/eri.11.155.

[4] P.R. Epstein, Climate change and emerging infectious diseases, Microbes Infect. 3 (2001) 747-754. doi:10.1016/S1286-4579(01)01429-0.

[5] N.D. Gundacker, R.J. Rolfe, J.M. Rodriguez, Infections associated with adventure travel: A systematic review, (2017). doi:10.1016/j.tmaid.2017.03.010.

[6] WHO | Schistosomiasis, WHO. (2017). http://www.who.int/mediacentre/factsheets/fs115/en/ (accessed August 22, 2017).

[7] Brazil, TabNet Win32 3.0: PCE - Programa de Controle da Esquistossomose Brasil, Brazilian Minist. Heal. (2017).

http://tabnet.datasus.gov.br/cgi/tabcgi.exe?sinan/pce/cnv/pcebr.def (accessed August 22, 2017).

[8] Brazil, A estação chuvosa do Norte da Região Nordeste terminará com Déficit Pluviométrico e Hídrico, Infoclima. 24 (2017). http://infoclima.cptec.inpe.br/ (accessed August 21, 2017).

[9] Outbreak of urogenital schistosomiasis in Corsica (France): an epidemiological case study, Lancet Infect. Dis. 16 (2016) 971-979. doi:10.1016/S14733099(16)00175-4.

[10] Schistosomiasis transmission in Europe, Lancet Infect. Dis. 16 (2016) 878-880. doi:10.1016/S1473-3099(16)30061-5.

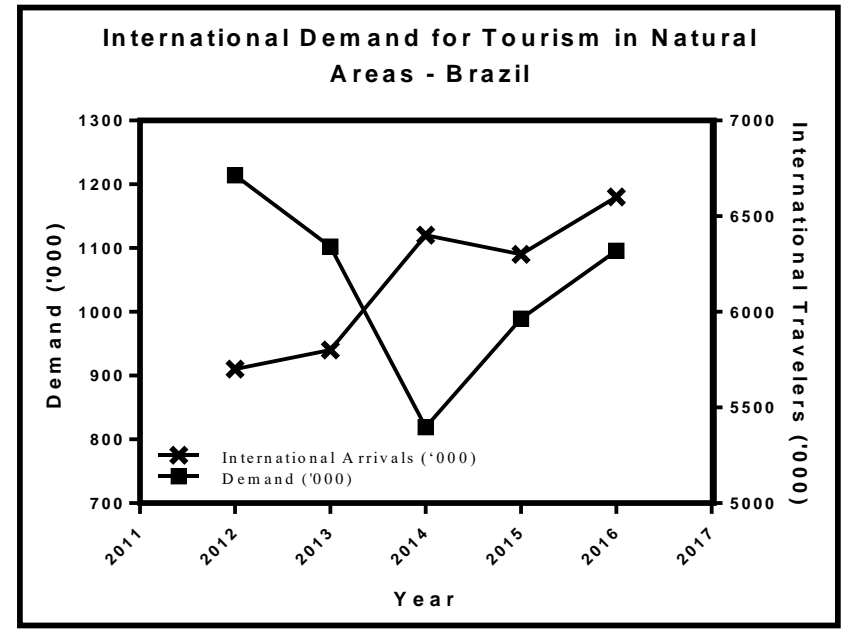


EVIDENCES ON BRAZILIAN TRAVELERS' HEALTH TROUGH THE EPIDEMIOLOGICAL PROFILE OF A PUBLIC TRAVEL MEDICINE CLINIC SÃO PAULO - 2012/2016.

\section{Introduction}

The travelers from emerging countries, as the BRICS countries (Brazil, Russia, India, China and South Africa), increased their numbers in international travel market, reaching $46.8 \%$ in 2016[1]. Protective measures were established by some developed countries agencies to avoid the importation of travel-related infectious diseases, with the incoming BRICs travelers, based on previous experience of unhealthy travelers, especially immigrants.

Developed countries improved their cross-border policies, creating websites with health orientations and protective measures for travelers, expansion of travel medicine clinics network and other actions to protect their travelers[2].

Some emerging countries established similar policies in recent years because your travelers start to visit some endemic regions around the world, thus demanding preventive travel health care.

In Brazil, travel medicine healthcare began in the 1990's decade[3] with the first Travel Medicine Clinic established in Rio de Janeiro (1997). After three years, the efforts made in that Clinic resulted in the creation of Instituto Emilio Ribas, in São Paulo. In 2001, the University of São Paulo - Medical School Health System (FMUSP-HC System) established the Ambulatório dos Viajantes. These clinics are public and provide free healthcare.

Travel medicine in Brazil was limited to prevent domestic diseases transmission, with the protocol of immunization check-up of travelers for preventable diseases, as Yellow Fever. The international outbound flow was not representative and aimed to developed countries considered safe.

Pré and Post-travel consultation is a service that increased in the last 5 years, due to the emergence of new international travel destinations, mainly in poverty nations.

In 2017, travel medicine clinics are available in all Brazilian state's capitals (Table 1) with high concentration in São Paulo State ( $\mathrm{n}=87$ clinics).

The aim of this retrospective study was the assessment of travelers' epidemiological profile who consults a Public Travel Medicine Clinic in São Paulo and to evaluate pretravel counseling as a preventive measure to avoid travel related diseases.

\section{Material and Methods}

Medical data of travelers assisted in Ambulatório dos Viajantes from January to December, 2016 were analyzed. The Ambulatório dos Viajantes - FMUSP-HC System provides free healthcare which currently receives around 20 travelers per month. We profiled the consultations screening by gender, age (0-18 years - underage traveler / 18-30 - Young Adult / 30-45 years - Adult / Over 45 years - Senior), travel destination and diseases that affected travelers by post travel consultation data. The study was approved by the Research Ethic Committee - FMUSP-HC System Process: CAAE 22239713.0.0000.0065 - Technical Report No 743.367 issued on July 23, 2014. 


\section{Results}

Travel medicine clinics in Brazil were 132 in 2014 and increased to 237 in 2016 (79.5\%) with more participation of private sector (from 33 to 112 units) and a quantitative development in São Paulo (87 units - 128.5\% - 2016).

In 10 years, Brazil presented a constant development in travel framework with 96.2 million of travelers in domestic travel by air. The second semester of 2015 presented a decrease in domestic travel flow of 7.4\% compared to the previous period in 2014[4].

The appointments in Ambulatório dos Viajantes accompanied this decline $(n=461$ 2012 / $n=280$ in 2016), due to economic instability that reduced the number of travels in Brazil (domestic and international).

From 2012 to 2014, the consultations peak occurred in January with similar figures in the following months, except in May (the clinic becomes an exclusive immunization center for influenza).

Appointments flow in 2015 and 2016 presented peaks in second semester, with 2 months of high increase (July and December - in 2015 / October and November in 2016).

Mean value of pre-travel counseling was $90.8 \%$ and post travel was 9.2\% from 2012 to 2016 (Table 2).

\section{- 2016 - Descriptive of Appointments.}

In 2016 (Table 3), there were 280 appointments with $93.92 \%$ of clients receiving some type of vaccine (regular or booster dose), and 36.4\% were immunized for Yellow Fever. It is an important protocol for immunization update in pre-travel counseling, to minimize the negative effects of low vaccination coverage (according to routine immunization established by World Health Organization) recorded in recent years (Table 4).

Travel destinations were distributed by continent as follow: Asia - 33.1\%, Africa $28.8 \%$, Central and South America - 24.8\%, Europe - (Germany - 1.8\%, 2 or more countries in EU - 5.8\%, Eastern Europe - 0.9\%), NZ and Australia (3.0\%) and North America/Canada (1.5\%).

The age group range starts from 4 to 76 years old with female predominance $-60.7 \%$ in pre-travel counseling. The post travel consultation group are age composed by $0-18$ (3.7\%), 18-30 (29.6\%), 30-45 (33.3\%) and over $45(33.3 \%)$, with male predominance $(62.9 \%)$.

The post travel consultation $(\mathrm{n}=27)$ was distributed in Malaria $(44.4 \%-6$ positive cases of P.falciparum, 4 positive cases of $P$. vivax and 2 unclassified), Fever (7.4\%), AGE- Acute Gastroenteritis (7.4\%), Hepatitis A (3.7\%), nausea (3.7\%), insect bite (3.7\%), abdominal pain (3.7\%), arthralgia (3.7\%), vaginal discharge $(3.7 \%)$ and under investigation cases $(18.5 \%)$.

\section{Discussion}

The recent participation of emerging countries in international travel, as the BRICS countries, requires the improvement of preventive measures to protect their citizens and to reduce the potential risk for infectious diseases importation.

In Brazil, travel medicine has improved in the last 5 years[5], and specialized clinics become an important tool for this prevention system[6]. 
In 2017, there are 237 travel medicine clinics, located in all Brazilian state capitals (27 States), with high concentration in São Paulo State ( $n=38$ in 2014 to $n=87$ in 2017)[7]. High investment by private sector in travel medicine indicates that is a promising and relevant segment (221.43\% - from 2014 to 2016).

This increase of facilities and decrease of travels in Brazil lead the consultations of Ambulatório dos Viajantes - FMUSP-HC System to a significant reduction in appointments (33.04\% in 2014-2015 and 7.89\% in 2015-2016) after the second half of 2015 (Figure 1B).

The main peak of consultations is in January occurred due to the summer school holidays in Brazil, that start in the end of December[8], but the families' vacation to international destinations present more intensity from the second week of the month when the pre-travel appointments growth. The second period is related to the winter school vacations, an expected situation due to the increase in travels. Through the appointments' flow, we assume that Brazilian travelers seek assistance in the imminence of the trip, a fact of concern.

Allied to travel medicine facilities, Brazilian Government stablished more preventive measures as the hand book for travelers, published in 2012 by Brazilian National Health Surveillance Agency, a government agency responsible for hygiene inspections in Brazilian territory[9]. It is a small guide for travelers with general information as how to check the individual health condition; expected infectious diseases in some tourist destinations, routes of infectious diseases' transmission, as well as protective measures and behavior during the trip.

Additionally, the Ministry of Health established a website with specific information for Brazilian Travelers to international destinations in 2014[10] which improved this protective network by regularly updating.

This web page includes links to the main health information websites for international travelers, treaties and agreements with some countries that provide free medical care for Brazilian citizens, location of public travel health clinics and immunization centers in Brazil, among other important information for safe travel in Brazil and abroad.

Despite this apparent reduction of tourism activity in Brazil, the current travel medicine clinics network should be maintained due to the importance as a source of strategic health planning for infectious diseases prevention.

The epidemiological profile of Ambulatório dos Viajantes presents this preventive orientation with mean value of $90.75 \%$ in pre-travel counseling.

The protocol for travelers' vaccine check-up contributes to cross border protection, reducing the potential for infectious disease importation and domestic spread due to travelers' immunization for main preventable infectious diseases. Important strategy if we consider the current low MMRV (70.69\% in 2017) and Polio (77\% in 2017) vaccine coverage in Brazil.

Age, destination and gender are important data to estimate the potential risks for travelers' exposition. Some studies present that young travelers are more susceptible to risks than senior travelers[11].

Our data present a significant flow of young travelers (31.07\%) to Asia (33.13\%), mainly to Southeast area (Thailand) with real potential for infectious disease importation[12]. 
However, international destinations most visited by Brazilians are South American' countries, with similar potential for neglected diseases outbreaks. North America and Europe, considered "safe places" by some Brazilian travelers, present potential risk as a source of preventable infectious diseases reemergence, as measles, in Brazil[13].

According to our current data, Brazilian travelers search Ambulatório dos Viajantes only for international travels, disregarding that some regions of the country are highly endemic, as observed in recent outbreaks of Malaria[14], Yellow Fever[15] and Measles[16].

The men group presents more risk behavior than women[17], as we may consider by the low male demand in pre-travel counselling (39.29\%) and the predominance in post travel consultation $(62.96 \%)$.

The Ambulatorio dos Viajantes - FMUSP-HC System shares its space with a referral laboratory for Malaria's diagnosis of the Superintendência de Controle de Endemias da Secretaria de Estado da Saúde de São Paulo - SUCEN (Superintendence of Control of Endemic Diseases of the State Department of Health of São Paulo) devoted to post-travel consultation, resulting in a great number of positive cases $(44.4 \%)$ in this biased population. Adult $(30-45-33.3 \%)$ and old age group (over $45-33.3 \%$ ) predominance in post travel consultation confirm the prevalence of other studies[11,18].

The same facility includes the Referral Center for Special Immunizations (CRIE FMUSP-HC System) with free delivery and administration of vaccines for preventable infectious diseases especially for travelers. This department issues the International Certificate of Vaccination or Prophylaxis.

Due to this social function for immunization, the clinic presents a relative reduction in appointments (Figure 1A) in the period of the national campaign for Influenza Flu vaccination which occurs in May (only 7 consultations were allowed in May 2016). Other travel medicine clinics in Brazil offer this assistance for routine vaccination as BCG, Hepatitis A and B, Rotavirus, Meningococcal C, Pentavalent (Diphtheria, Tetanus, Pertussis, Haemophilus influenzae type $\mathrm{b}$ meningitis, and Poliomyelitis), Pneumococcal, Poliomyelitis, Yellow Fever, MMR vaccine, Tetravalent (MMR+Varicella), DTP (Diphtheria, Tetanus and Pertussis), adult DPLA (Diphtheria and Tetanus), Influenza, and Quadrivalent HPV[3].

Allied to this strategy of vaccine coverage surveillance, in the pre-travel counseling, according to patients travel itinerary, the physicians assists the patients over the main infectious diseases in the area to be visited and the most important, they advise for specific preventive measures to adopt.

These protocols reduced post travel consultations (9.25\%) and present that travelers are more concerned. Current rates of pre and post-travel assistance are similar to travel medicine clinics in developed countries[18-21].

\section{Conclusion}

The current increase of Brazilian participation in International Travel was followed by the establishment of protective measures.

The implementation of counseling website for travelers and the expansion of travel medicine clinics indicate the potential changing of Brazilian travelers' behavior, 
according to the high percentage of pre-travel counseling conducted by Ambulatório dos Viajantes - FMUSP-HC System.

According to our data, women seek more for pre-travel medicine assistance than men, and Southeast Asia is the main travel destination visited by the patients that seek pretravel consultation, especially the young adults to Thailand. The post travel consultation has male predominance and the low number indicates that pre-travel counseling is an important action to protect the travelers.

Immunization protocol adopted in Ambulatório dos Viajantes becomes important, due to current low vaccine coverage in Brazil.

\section{References}

[1] United Nations World Tourism Organization. Tourism Highlights - 2016. Geneva: 2016. doi:10.18111/9789284418145.

[2] Fujita DM, Nali LH da S, Urbano PR, Soeiro DM, Andrade HF de. The fast transmission of infectious diseases around the world - a new concern to the public health. Braz J Infect Dis 2016;20:513-5. doi:10.1016/j.bjid.2016.06.003.

[3] Igreja RP. Medicina de Viagem: uma nova área de atuação para o especialista em Doenças Infecciosas e Parasitárias. Rev Soc Bras Med Trop 2003;36:53940. doi:10.1590/S0037-86822003000400020.

[4] Brazil. Dados do Anuário do Transporte Aéreo. Brasília: 2016.

[5] Chaves T do SS, Alves JR, Lopes MH. Pre-travel counselling in Brazil. Travel Med Infect Dis 2015;13:340-1. doi:10.1016/j.tmaid.2015.03.007.

[6] Horvath LL, Murray CK, Dooley DP, J T. Effect of Maximizing a Travel Medicine Clinic-s Prevention Strategies. J Travel Med 2006;12:332-7. doi:10.2310/7060.2005.12606.

[7] Brazil. Travel Medicine Clinics - Anvisa 2017. http://portal.anvisa.gov.br/centros-de-orientacao-do-viajante (accessed March 16, 2017).

[8] dos Santos RP, Konkewicz LR, Nagel FM, Lisboa T, Xavier RC, Jacoby T, et al. Changes in hand hygiene compliance after a multimodal intervention and seasonality variation. Am J Infect Control 2013;41:1012-6. doi:10.1016/j.ajic.2013.05.020.

[9] Brazil. Saúde do Viajante. Brasília: ANVISA; 2012.

[10] Brazil. Viajante BR. Brazilian Minist Heal 2014. http://portalsaude.saude.gov.br/index.php/oministerio/principal/secretarias/svs/viajante (accessed May 2, 2017).

[11] Vilkman K, Pakkanen SH, Lääveri T, Siikamäki H, Kantele A. Travelers' health problems and behavior: prospective study with post-travel follow-up. BMC Infect Dis 2016;16:328. doi:10.1186/s12879-016-1682-0.

[12] Dash AP, Bhatia R, Sunyoto T, Mourya DT. Emerging and re-emerging arboviral diseases in Southeast Asia. J Vector Borne Dis n.d.;50:77-84.

[13] Nali LH, Fujita DM, Salvador FS, Fink MC, F de AH, Pannuti CS, et al. Potential measles transmission risk in mass gatherings: Are we safe for the Olympic games--Rio 2016? 2016. doi:10.1093/jtm/taw026.

[14] Garcia M. Situação epidemiológica das arboviroses e malária Brasil, 2018. Brasília: 2018. 
[15] Fujita DM, da Silva Nali LH, Salvador FS, de Andrade Júnior HF.

Recommendations for travellers during the yellow fever outbreaks in Brazil2018. J Travel Med 2018;25. doi:10.1093/jtm/tay016.

[16] Brazil. Situação dos Casos de Sarampo nos Estados de Roraima e Amazonas2018 Monitoramento da situação epidemiológica de sarampo nos estados de Roraima e Amazonas. Brasilia: 2018.

[17] Aggleton P, Bell SA, Kelly-Hanku A. 'Mobile men with money': HIV prevention and the erasure of difference. Glob Public Health 2014;9:257-70. doi:10.1080/17441692.2014.889736.

[18] Bühler S, Rüegg R, Steffen R, Hatz C, Jaeger VK. A Profile of Travelers-An Analysis From a Large Swiss Travel Clinic. J Travel Med 2014;21:324-31. doi:10.1111/jtm.12139.

[19] Quality A for HR and, Merrina F, Gagnayre R, Bouchaud O. A descriptive study of advising practices during travel health consultations in France. J Travel Med 2017;25:582-602. doi:10.1093/jtm/tax042.

[20] Rowe K, Chaves N, Leder K. Challenges to providing pre-travel care for travellers visiting friends and relatives: an audit of a specialist travel medicine clinic. J Travel Med 2017;24. doi:10.1093/jtm/tax038.

[21] Rodrigo Saez L, Riestra Menendez S, Fernandez Rodriguez E, Fernandez Velazquez MR, Garcia Alonso S, Lauret Brana ME. Epidemiological study of the prevalence of Helicobacter pylori infection in the general population in Asturias, Spain. Rev Esp Enferm Dig 1997;89:511-22.

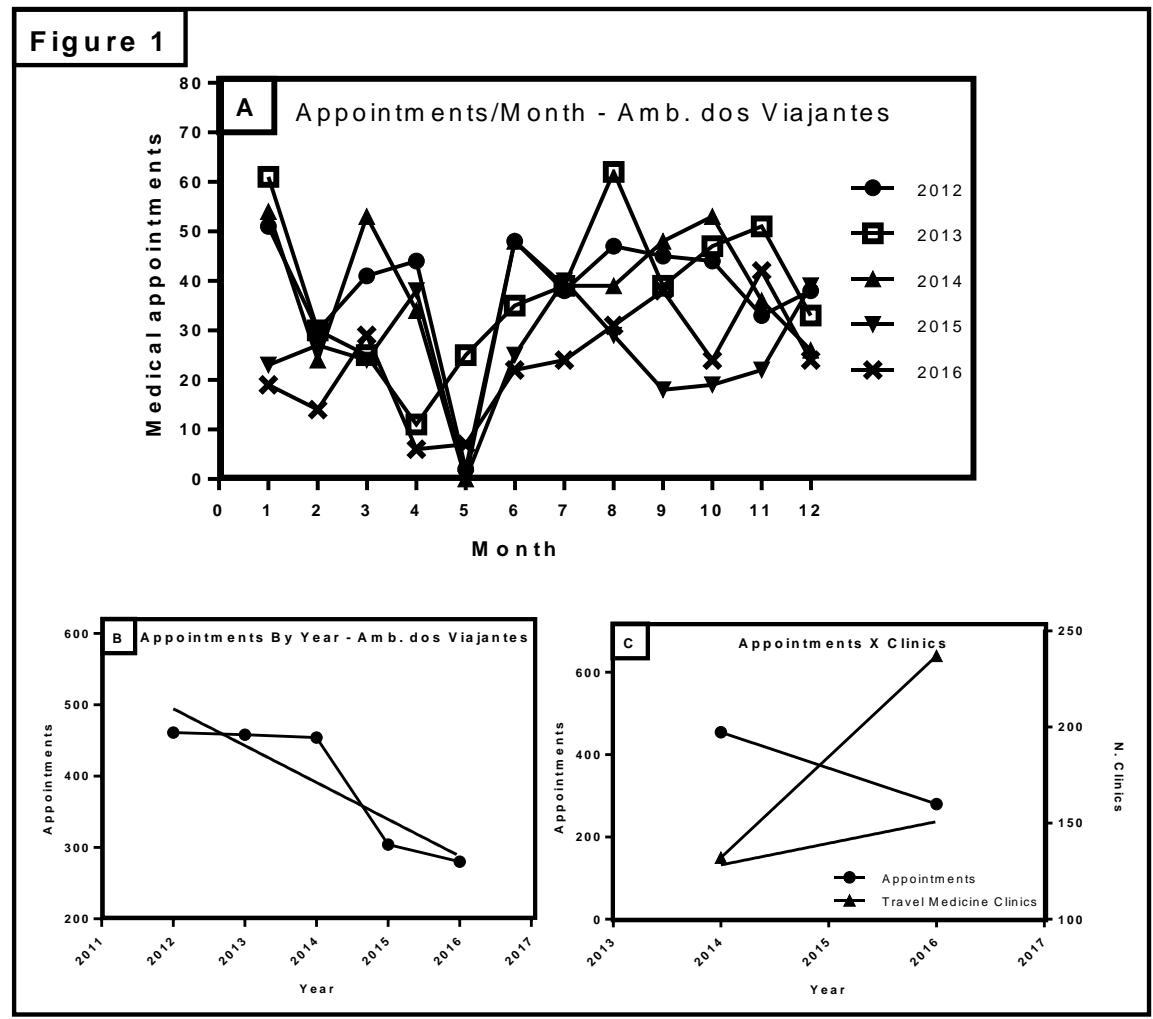




\section{LISTA DE ABREVIAÇÕES}

\begin{tabular}{|c|c|}
\hline$€$ & Euro \\
\hline ANVISA & Agência Nacional de Vigilância Sanitária \\
\hline APPA & American Pet Products Association \\
\hline $\mathrm{B} 2 \mathrm{C}$ & Business to Consumer \\
\hline $\mathrm{BCB}$ & Banco Central do Brasil \\
\hline BEPA & $\begin{array}{l}\text { Boletim Epidemiológico Paulista da Secretaria de Saúde do } \\
\text { Governo do Estado de São Paulo }\end{array}$ \\
\hline BNS & Base Nacional de Saúde \\
\hline BRICS & Brasil, Rússia, India, China e África do Sul \\
\hline CRIE & Centros de Referência para Imunobiológicos Especiais \\
\hline $\mathrm{CVE}-\mathrm{SP}$ & $\begin{array}{l}\text { Centro de Vigilância Epidemiológica - Prof. Alexandre } \\
\text { Vranjac-São Paulo }\end{array}$ \\
\hline DATASUS & Departamento de Informaática do SUS \\
\hline DGCIS & $\begin{array}{l}\text { Direction Générale de la Compétitivité, de l'Industrie et des } \\
\text { Services }\end{array}$ \\
\hline EU & European Union \\
\hline EUROSTAT & Gabinete de Estatísticas da União Europeia \\
\hline FMUSP & Faculdade de Medicina da Universidade de São Paulo \\
\hline FMUSP-HC & $\begin{array}{l}\text { Hospital das Clínicas da Faculdade de Medicina da } \\
\text { Universidade de São Paulo }\end{array}$ \\
\hline IET & Instituto de Estudios Turísticos \\
\hline ISTAT & Istituto Nazionale di Statistica \\
\hline LV & Leishmaniose Visceral \\
\hline MS & Ministério da Saúde \\
\hline MTur & Ministério do Turismo \\
\hline OMS & Organização Mundial de Saúde \\
\hline OMT & Organização Mundial do Turismo \\
\hline PIB & Produto Interno Bruto \\
\hline PNI & Programa Nacional de Imunização \\
\hline $\mathrm{R} \$$ & Real \\
\hline SINAN Net & Sistema de Informação de Agravos de Notificação \\
\hline SIS & Sistema de Informações - Schengen \\
\hline SRC & Síndrome da Rubéola Congênita \\
\hline SUCEN & $\begin{array}{l}\text { Superintendência de Controle de Endemias da Secretaria de } \\
\text { Estado da Saúde de São Paulo }\end{array}$ \\
\hline SUS & Sistema Único de Saúde \\
\hline SUSEP & Superintendência de Seguros Privados \\
\hline Tabnet & Informações de Saúde \\
\hline TFEU & Treaty on the Functioning of The European Union \\
\hline UNWTO & United Nations World Tourism Organization \\
\hline USA & Unite States of America \\
\hline USD & Dólar Americano \\
\hline WHO & World Health Organization \\
\hline
\end{tabular}




\section{SUMÁRIO}

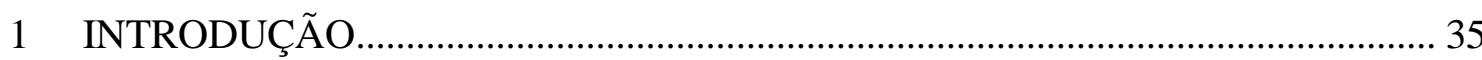

1.1 O aumento de fluxo de viagens e a adoção de novas políticas de fronteira frente às doenças infecciosas

1.2 Mercado turístico europeu: crise do turismo interno e a busca por novos mercados consumidores................................................................... 38

1.3 Tratado de Schengen e os fluxos de deslocamento humano ............................. 41

1.4 Os fluxos de viajantes brasileiros ao exterior e o aumento de risco potencial para exposição às ocorrências de saúde - O consumo de

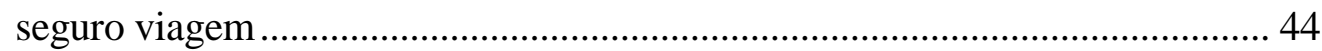

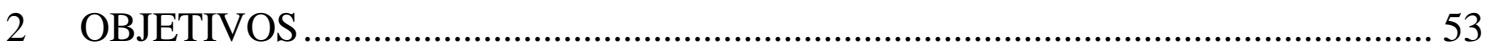

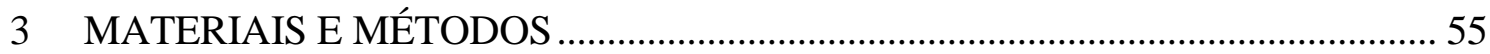

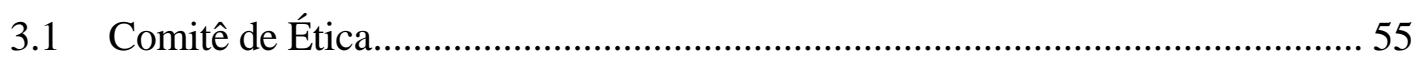

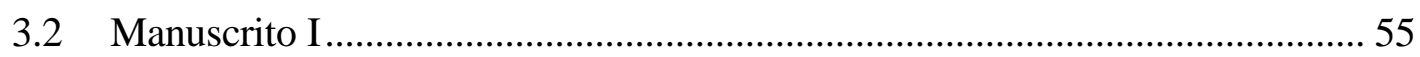

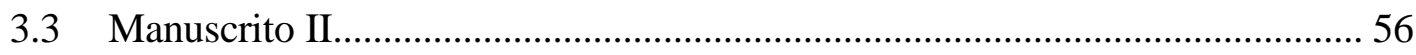

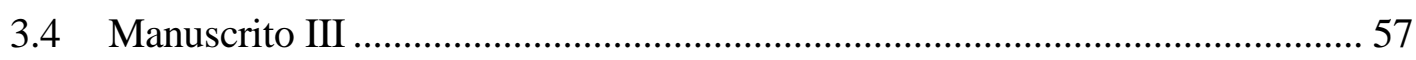

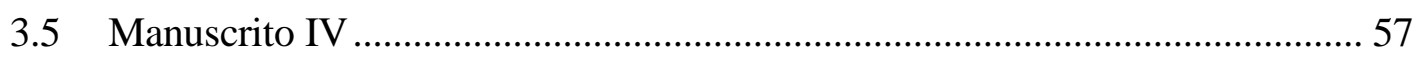

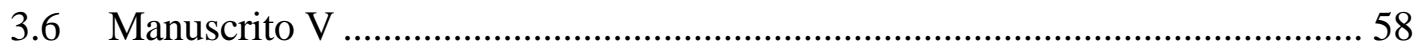

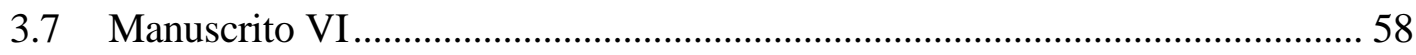

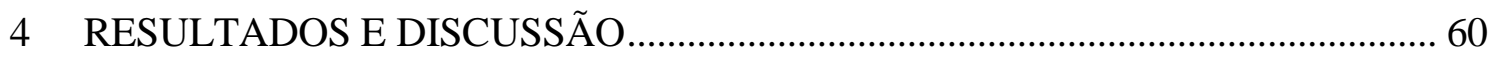

4.1 A rápida transmissão de doenças infecciosas no mundo - Uma nova questão para a saúde pública .................................................................6 60

4.2 Rotas de entrada para o vírus Zika no Brasil após a Copa do Mundo de 2014: Novas possibilidades ................................................................ 64

4.3 Risco potencial de transmissão do Sarampo em eventos de massa: Medidas preventivas para os Jogos Olímpicos - Rio 2016 69

4.4 Medidas preventivas para instalações de hospedagem "Pet Friendly": Associação entre rota de expansão da leishmaniose em São Paulo e medidas preventivas para o deslocamento de animais domésticos

4.5 Mudanças climáticas, enchentes e aumento de atividades de lazer em áreas naturais: $\mathrm{O}$ risco potencial para o aumento de casos de Esquistossomose

4.6 Evidências da saúde dos viajantes brasileiros por meio do perfil epidemiológico de uma clínica pública para viajantes - São Paulo 2012/2016 
5 CONCLUSÕES.

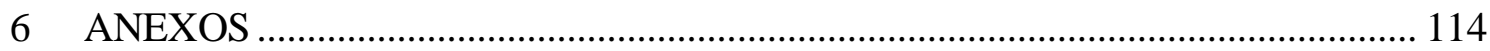




\section{INTRODUÇÃO}

\subsection{O AUMENTO DE FLUXO DE VIAGENS E A ADOÇ̃̃o DE NOVAS POLÍTICAS DE FRONTEIRA FRENTE ÀS DOENÇAS INFECCIOSAS}

A atividade turística no Brasil está em desenvolvimento crescente apresentando a marca de viagens internas em 206 milhões em 2014. O número de brasileiros que viajaram pelo país chegou a 60 milhões, superando o recorde de 58,9 milhões de 2011, segundo análise do Departamento de Estudos e Pesquisas do Ministério do Turismo .

Quanto ao fluxo de turismo receptivo internacional no Brasil, constata-se o mesmo processo de desenvolvimento ao longo dos anos, obtendo-se 6.588 .770 estrangeiros desembarcando no Brasil pelas mais diferentes vias de acesso no ano de 2017 (Gráfico 1).

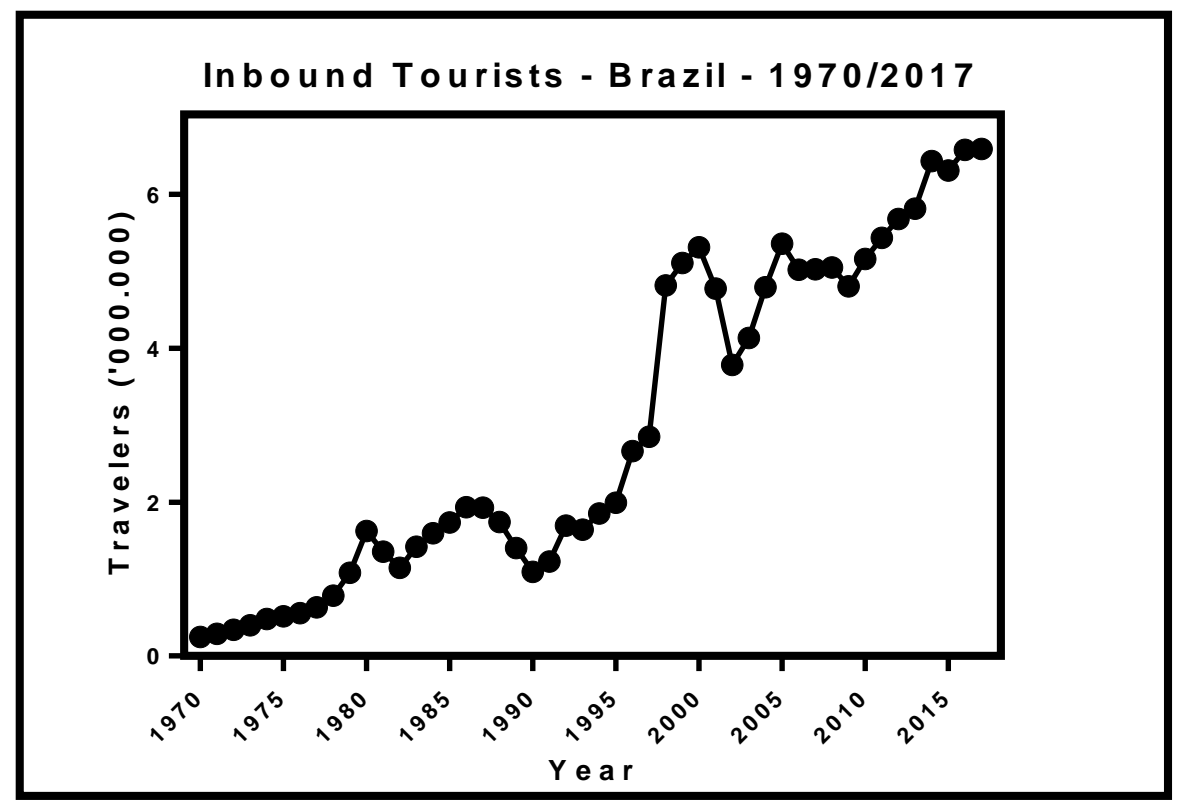

Gráfico 1 - Chegadas de turistas ao Brasil - 1970-2017

Fonte: Departamento de Polícia Federal e Ministério do Turismo ${ }^{2}$ 
Percebe-se um fluxo grande de pessoas que viajam para o país, bem como internamente fazendo com que o Turismo, enquanto atividade econômica, estabeleça novas necessidades como a segurança destes viajantes.

Neste sentido, a formalização de procedimentos e necessidades para a questão além da qualidade dos serviços prestados amplia-se para a relação de segurança e saúde dos viajantes, sendo uma política em estruturação no país. Segundo Silva ${ }^{3}$ :

\begin{abstract}
No campo prático, as iniciativas disponíveis de atenção ao turista brasileiro limitam-se à oferta de aconselhamento médico individual antes da viagem recomendação de vacinas necessárias previstas ou não no Programa Nacional de Imunização (PNI) e assistência após a viagem. Esses serviços são considerados projetos de pesquisa e extensão em instituições acadêmicas de iniciativa da medicina de viagem. Apesar da inserção dos Centros de Referência para Imunobiológicos Especiais (CRIE) nessas unidades, essas ações não foram absorvidas como política de governo que pudesse garantir atendimento a toda população de viajantes. (p.16-17)
\end{abstract}

Apesar da constante melhoria empreendida pelo Ministério do Turismo por meio dos programas de capacitação, que envolvem desde projetos voltados para manipulação de alimentos e sua comercialização até campanhas de sexo seguro e diminuição do turismo sexual, ainda não se apresentam como uma política efetiva voltada para a segurança e saúde do viajante no Brasil.

Não obstante, o Brasil é signatário de vários tratados e convenções internacionais relacionados às normas de segurança e saúde, porém, são ações setorizadas por modal turístico não se estabelecendo numa política única.

Em vista do aumento da participação de países emergentes no fluxo internacional de viagens ( 46\% nos últimos 10 anos $)^{4}$, a União Europeia estruturou em 
2007 a Convenção Schengen ${ }^{5}$, que surge da necessidade de livre trânsito e comércio oriundas da formação da Comunidade Europeia, sendo uma forma de permitir aos cidadãos dos países signatários transitarem livremente, incluindo-se garantias ao seu bem-estar enquanto estiverem dentro deste espaço. Entretanto, este livre deslocamento poderia colocar o sistema de saúde pública dos países receptores em risco, uma vez que o trânsito livre possibilita a elevação do contingente humano local.

Neste trabalho analisamos as medidas internas e externas adotadas pelos países signatários, bem como o seu reflexo para o turismo internacional, em principal no Brasil, realizando um levantamento sobre os fluxos de turistas brasileiros após a implantação do tratado, além de analisar o segmento de seguro viagem durante este período, tendo-se como propostas a reflexão sobre a possível adoção deste tipo de convenção em nosso país, devido as suas dimensões continentais, que se assemelham com o Espaço Schengen em termos de necessidades na área de saúde, bem como de outras medidas protetivas, conforme os estudos realizados sobre potencial de importação e exportação de doenças infecciosas, seja pelo turista brasileiro em viagem ao exterior, seja pela visita de turistas estrangeiros ao nosso país.

Analisamos 3 momentos distintos, sendo o primeiro referente à compreensão da Convenção Schengen e suas diretrizes tendo-se a necessidade de realizar uma revisão sistemática desta normativa para entender os seus desdobramentos nos países membros da União Europeia, bem como analisar a importância do Turismo como atividade econômica para a comunidade, sendo o volume de turismo interno utilizado como parâmetro no intervalo 2005 a 2011, devido à disponibilidade desta informação. 
Estes materiais secundários foram coletados nos arquivos eletrônicos do Parlamento Europeu e do órgão de estatística oficial da União Europeia ${ }^{6}$.

A segunda etapa do trabalho foi construída com a coleta de informações de volume de turistas brasileiros recebidos, sendo o primeiro colocado no ranking os Estados Unidos. As seleções dos dois principais países receptores europeus para realizarmos um estudo comparativo, em vista da proposta inicial, culminaram na França e Espanha pelo volume de turistas brasileiros recebidos no período de 2002 a 2012, sendo este o método de triagem e seleção. Os dados foram obtidos com base nos relatórios da Organização Mundial do Turismo $^{7}$ e da consultoria independente Euromonitor $^{8}$, sendo confirmados por pesquisa direta (entrevista) junto aos órgãos de fomento de Turismo destes países.

A terceira etapa, e mais importante em virtude de se poder analisar a eficácia da Convenção Schengen foram obtidos junto aos relatórios de produtividade do segmento de Seguro de Viagem, sendo utilizados os dados dos órgãos de fiscalização do

segmento de seguros privados, tendo-se a INSURANCE EUROPE $^{9}$ e a Superintendência de Seguros Privados $-\operatorname{SUSEP}^{10}$ como fontes principais, além dos balanços anuais das companhias de seguro europeias, sendo selecionada a Allianz Assistance Group devido ao fato de ter a maior lucratividade dentro do segmento na Europa.

\subsection{MERCADO TURÍSTICO EUROPEU: CRISE DO TURISMO INTERNO E A BUSCA POR NOVOS MERCADOS CONSUMIDORES}


A nova realidade turística europeia é perceptível pelos fluxos internos (Gráfico 2), tendo-se um aumento considerável a partir da implantação da Convenção Schengen por meio do tratado de Lisboa $^{11}$, porém, devido à crise financeira de 2009 temos a diminuição do turismo interno, tanto em viagens à lazer, mas, principalmente nos fluxos de viagens à negócios, sendo necessário repor tal demanda para manter tanto a atividade turística local quanto para gerir novas fontes de recursos financeiros para a Europa em crise.

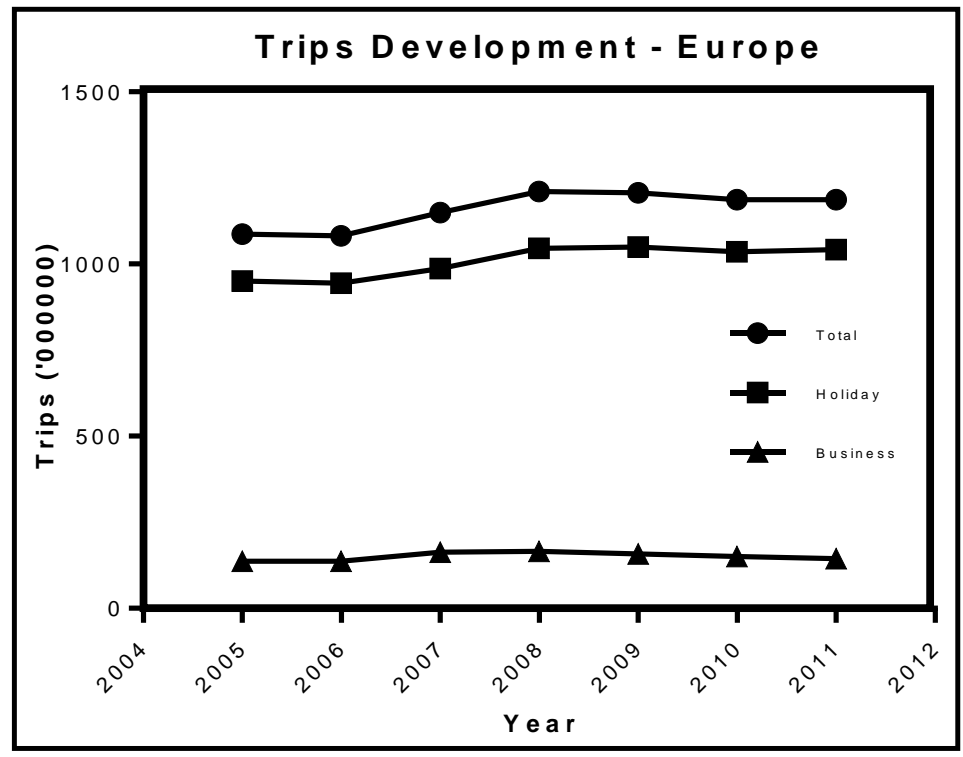

Gráfico 2 - Número de viagens realizadas por turistas europeus dentro do continente

Fonte: Gabinete de Estatísticas da União Europeia - EUROSTAT ${ }^{6}$.

Apesar da aparente elevação no número de viagens de lazer, o fator econômico de rentabilidade deve ser levado em consideração, pois apesar de se manter um número elevado de deslocamentos, mesmo após a crise financeira, ocorre a permanência menor nas localidades visitadas. De 2009 a 2011, o período de estadia de longa duração (de 7 
para mais) diminui cerca de $73 \%$. Isto significa que os viajantes, por ficarem menos tempo nas cidades visitadas, acabam gastando menos com hospedagem, alimentação e serviços turísticos locais, gerando assim menos dividendos. Conforme o Gráfico 3, podemos notar a diminuição na rentabilidade das localidades devido ao menor tempo de permanência.

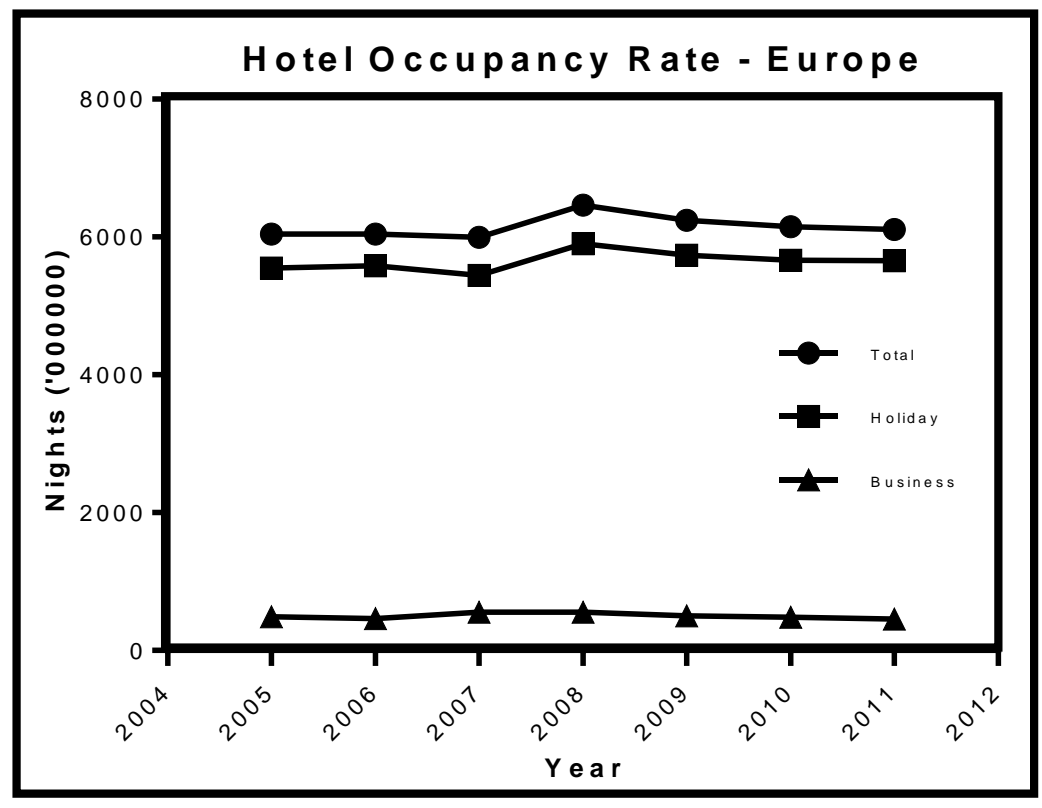

Gráfico 3 - Diárias em hotéis consumidas por turistas europeus dentro do continente Fonte: EUROSTAT ${ }^{6}$.

O arrefecimento do turismo interno indica a necessidade de substituição por novos mercados, uma vez que a atividade turística representa mais de $10 \%$ do Produto Interno Bruto (PIB) da Comunidade Europeia ${ }^{12}$, sendo necessário estabelecer normas internas para organizar os fluxos de viajantes tanto internos quanto externos para que o espaço europeu não tenha possíveis prejuízos ou danos oriundos dessas novas massas que passam a se deslocar pela Europa, principalmente na questão de saúde. 


\subsection{TRATADO DE SCHENGEN E OS FLUXOS DE DESLOCAMENTO HUMANO}

O Tratado de Schengen origina-se em 14 de junho de 1985, tendo inicialmente os seguintes países signatários: Alemanha, Bélgica, França, Luxemburgo e Países Baixos; em virtude do acordo de livre circulação de pessoas que vigorava desde 1960, conforme dados da Comunidade Europeia ${ }^{5}$

A ampliação geográfica do tratado se deu pela instituição da Convenção Schengen que se consolidou somente após o Tratado de Lisboa em 13 de dezembro de 2007, tendo-se, além dos países membros da Comunidade Europeia, a inclusão da Islândia, Noruega e Suíça.

O Espaço Schengen (Alemanha, Áustria, Bélgica, Dinamarca, Eslováquia, Eslovénia, Espanha, Estónia, Finlândia, França, Grécia, Hungria, Islândia, Itália, Letónia, Liechtenstein, Lituânia, Luxemburgo, Malta, Noruega, Países Baixos, Polónia, -Portugal, República Checa, Suécia e Suíça), constituído pelos países signatários da convenção, permitem o livre trânsito de seus cidadãos, sem a obrigatoriedade de passaportes e vistos por se tratar de um espaço de "liberdade, segurança e justiça".

Além das situações mencionadas anteriormente, a convenção ainda prevê as seguintes questões para autonomia e controle dos países em relação as suas fronteiras:

- Procedimentos para pedido de asilo;

- Atribuição de vistos de curta duração;

- Práticas de combate ao tráfico de drogas;

- Implantação de um Sistema de Informações - Schengen (S.I.S.); 
- Reorganização do controle nos aeroportos abertos ao tráfico internacional; e

- Controles efetivos das fronteiras externas.

Analisando-se as premissas de autopreservação, nota-se que há a necessidade, mesmo num contexto de livre acesso, de estabelecer limites internos no intuito de se evitar o colapso das estruturas basilares da sociedade como finanças, educação, segurança e saúde.

O direito ao atendimento de saúde para os viajantes europeus dentro do espaço Schengen é garantido pela Diretriz 2011/24/European Union do Parlamento e Conselho Europeu de 09 de março de $2011^{13}$, com base na versão consolidada do THE TREATY ON THE FUNCTIONING OF THE EUROPEAN UNION - TFEU, título XIV - PUBLIC HEALTH - Artigo 168, parágrafo 7:

Union action shall respect the responsibilities of the Member States for the definition of their health policy and for the organisation and delivery of health services and medical care. The 9.5.2008 EN Official Journal of the European Union C 115/123 responsibilities of the Member States shall include the management of health services and medical care and the allocation of the resources assigned to them. The measures referred to in paragraph 4(a) shall not affect national provisions on the donation or medical use of organs and blood ${ }^{l}$.

A mesma diretriz ainda garante o reembolso dos gastos médicos ao país de origem do viajante europeu:

\footnotetext{
${ }^{11}$ Tradução livre do autor: "A ação da União respeita as responsabilidades dos Estados-Membros no que se refere à definição das respetivas políticas de saúde, bem como à organização e prestação de serviços de saúde e de cuidados médicos. As responsabilidades dos Estados-Membros incluem a gestão dos serviços de 9.5.2018 Jornal Oficial da União Europeia C 115/123 PT saúde e de cuidados médicos, bem como a repartição dos recursos que lhes são afetados. As medidas a que se refere a alínea a) do n.o 4 não prejudicam as disposições nacionais sobre doação de órgãos e de sangue ou utilização dos mesmos para fins médicos."
} 
The right to reimbursement of the costs of healthcare provided in another Member State by the statutory social security system of patients as insured persons has been recognised by the Court of Justice in several judgements. The Court of Justice has held that the Treaty provisions on the freedom to provide services include the freedom for the recipients of healthcare, including persons in need of medical treatment, to go to another Member State in order to receive it there. The same should apply to recipients of healthcare seeking to receive healthcare provided in another Member State through other means, for example through eHealth care. ${ }^{2}$

Neste último quesito criou-se o Visto Schengen que salvaguarda a vida do viajante doméstico em território diferente de sua moradia, evitando-se assim a oneração do setor de saúde pública local, visto que em grande parte do território europeu ocorre o acesso ao serviço público de saúde desde que o beneficiário esteja em dia com as contribuições ao sistema de saúde de seu país, bem como por período determinado e valor, conforme a decisão individual de cada país.

A referida situação também impede que cidadãos portadores de dupla nacionalidade europeia sobrecarreguem o serviço público de saúde. Conforme dados do Istituto Nazionale di Statisticas - ISTAT $^{14}$ somente no ano de 2011 foram solicitados 56 mil pedidos de cidadania italiana, o que possibilita ao portador o livre acesso à comunidade europeia quando da sua concessão, porém, não diretamente aos serviços de assistência social e de saúde pública.

\footnotetext{
2 Tradução Livre do Autor: "O direito ao reembolso dos custos de cuidados médicos prestados noutro Estado-Membro pelo regime obrigatório de segurança social, enquanto pessoas seguradas, foi reconhecido pelo Tribunal de Justiça em diversos acórdãos. O Tribunal de Justiça considerou que as disposições do Tratado relativas à liberdade de prestação de serviços incluem a liberdade dos beneficiários de assistência de saúde, incluindo as pessoas que necessitam de tratamento médico, se deslocarem para outro Estado-Membro para lá serem tratados. O mesmo se aplica aos beneficiários assistência médica que procuram receber cuidados de saúde prestados noutro Estado-Membro por outros meios, por exemplo, através de cibermedicina."
} 
Tendo-se este problema interno resolvido, o viajante estrangeiro ao bloco torna-se o grande problema com relação às fronteiras e a saúde pública, pois apesar de impulsionar a economia local pela aquisição de bens e serviços, o mesmo reflete na possível ocupação de leitos e custos operacionais de saúde em países cujos tratados e convênios permitiam a prestação de assistência gratuita, bem como pelas condições pré-existentes de doenças relacionadas aos locais de origem do viajante, que poderiam infestar o continente europeu.

Neste sentido, o Tratado de Lisboa, convencionado no ano de 2007, implantou a obrigatoriedade do seguro viagem para turistas estrangeiros provenientes de regiões fora do bloco, sendo uma forma de conter estas possíveis situações, além de representar uma fonte de renda para a Europa, pois as companhias seguradoras devem possuir sua sede em um dos países pertencentes ao grupo, conforme determinação estabelecida na Convenção Schengen ${ }^{15}$.

Ainda em relação às determinações, nota-se um valor mínimo de cobertura estabelecido em 30.000,00 Euros, o que elevou os preços cobrados para aquisição dos seguros viagem.

Constata-se assim que a Convenção Schengen estabelece critérios rígidos para salvaguardar seus países membros, tanto em relação aos deslocamentos internos, mas, principalmente, em relação à recepção dos grupos externos ao bloco.

\subsection{OS FLUXOS DE VIAJANTES BRASILEIROS AO EXTERIOR E O AUMENTO DE RISCO POTENCIAL PARA EXPOSIÇÃO ÀS OCORRÊNCIAS DE SAÚDE - O CONSUMO DE SEGURO VIAGEM}


A estabilidade econômica brasileira aliada ao cenário de prosperidade vivida pelo país nos últimos anos tem permitido o aumento no consumo de turismo tanto interno quanto externo pelo público brasileiro. Dados do Ministério do Turismo MTur ${ }^{1}$ indicam que cerca de 60 milhões de brasileiros viajaram pelo país, bem como os dados do Banco Central do Brasil $-\mathrm{BCB}^{16}$ indicam que no ano de 2012, os brasileiros gastaram USD 22,2 bilhões em viagens no exterior, sendo 4,5\% superior ao ano anterior.

O país mais visitado pelos brasileiros continua sendo os Estados Unidos da América, principalmente após a crise econômica sofrida pelo país em 2008, quando vários bancos quebraram devido à "bolha" imobiliária que gerou a recessão econômica. Tal situação proporcionou a valorização do real, tornando ainda mais atrativo o destino americano. Segundo dados do Departamento de Comércio Americano $^{17}$, o volume de turistas brasileiros nos Estados Unidos cresceu $453 \%$ na última década (2002/2012), apresentando um número total de 1.791 .000 turistas no ano de 2012 .

O continente europeu também se consolidou como destino de férias para os brasileiros, que, devido à valorização da moeda nacional aliada à crise econômica vivida pelos países europeus, possibilitou aos brasileiros conhecerem o "velho mundo" nos últimos anos, mesmo com problemas como o embargo para a entrada de brasileiros na Espanha em 2008/2009, protestos e manifestações por toda a Europa, e, principalmente a implantação da Convenção Schengen em 2008. Mesmo com este cenário, França e Espanha ainda se encontram como os principais destinos de turismo no mundo, tendo-se 79,1 milhões e 58,5 milhões de turistas, respectivamente, segundo 
dados da Organização Mundial do Turismo $-\mathrm{OMT}^{18}$. Os brasileiros foram responsáveis por fluxos consideráveis para os dois países, tendo-se 610.000 turistas para a França e 718.000 para a Espanha, mesmo com tantos empecilhos no ano de 2012.

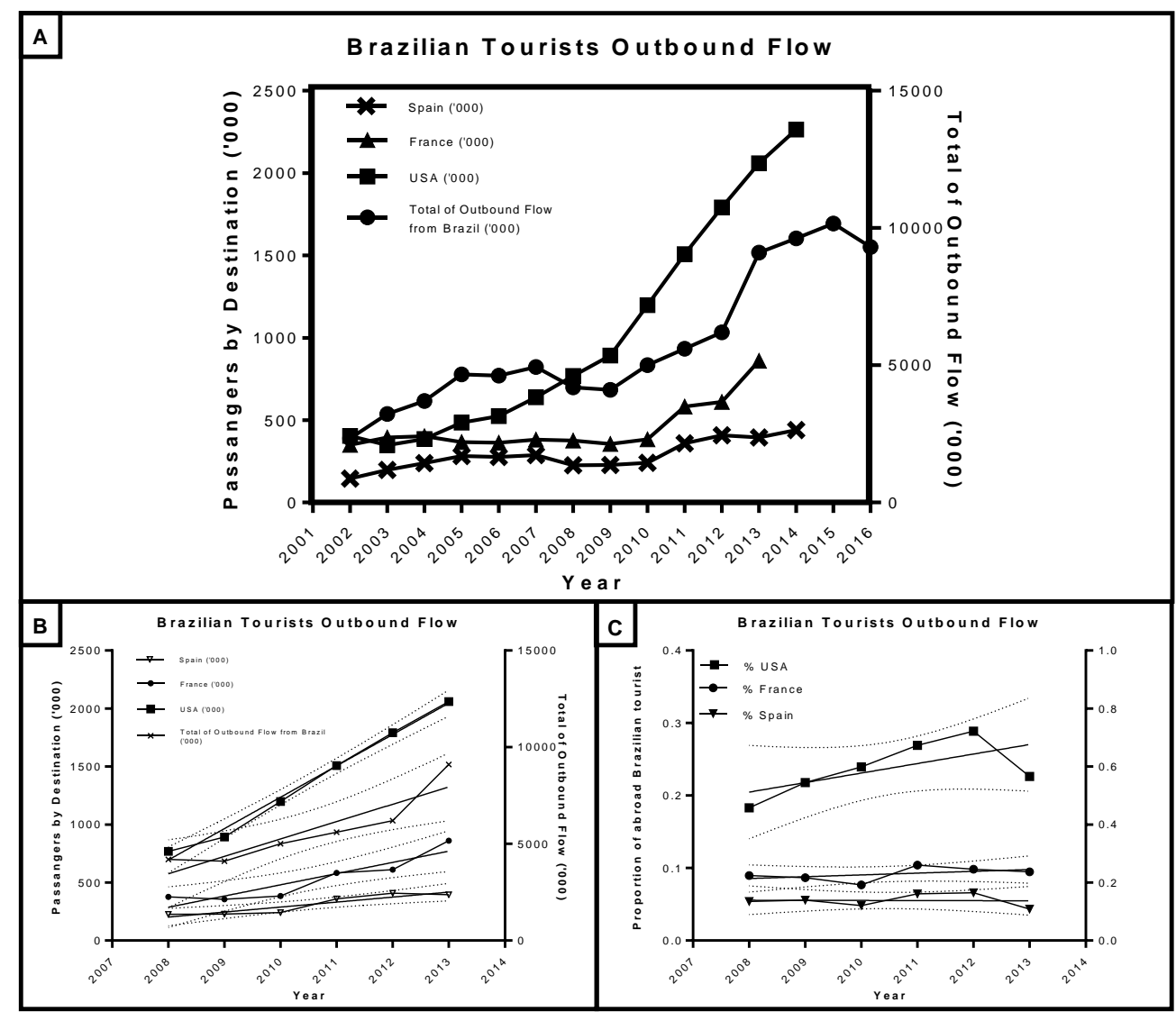

Gráfico 4 - Evolução dos fluxos turísticos de brasileiros no exterior Fonte: EUROMONITOR ${ }^{8}$, Direction générale de la compétitivité, de l'industrie et des services DGCIS $^{19}$, Instituto de Estudios Turísticos - IET ${ }^{20} \mathrm{e}$ Department of Commerce - USA ${ }^{17}$

Constata-se o desenvolvimento do turismo internacional por brasileiros com acentuada elevação a partir do ano de 2009, porém, analisando-se os dois principais representantes do continente europeu, percebe-se que há declínio / manutenção dos fluxos, tendo-se em contrapartida a elevação no número de turistas para os Estados Unidos, fato este estimulado por três situações importantes: desvalorização da moeda 
americana, facilidade para concessão de vistos iniciada em 2009 e a imposição do seguro viagem nos países da Comunidade Europeia.

Os itens mencionados contrastam com as normas impostas pela Convenção de Schengen que, ao invés de facilitar o acesso, criam barreiras para o consumo de turistas internacionais, impondo até, numa visão mais inteligente e estratégica, que se trata de um "pseudo imposto" para o turista estrangeiro. Não obstante, a situação econômica europeia propicia o consumo deste destino pelos brasileiros, que acabam desconsiderando estes fatores como impeditivos.

Os dados da Superintendência de Seguros Privados - SUSEP ${ }^{10}$ comprovam esta situação conforme o gráfico abaixo:

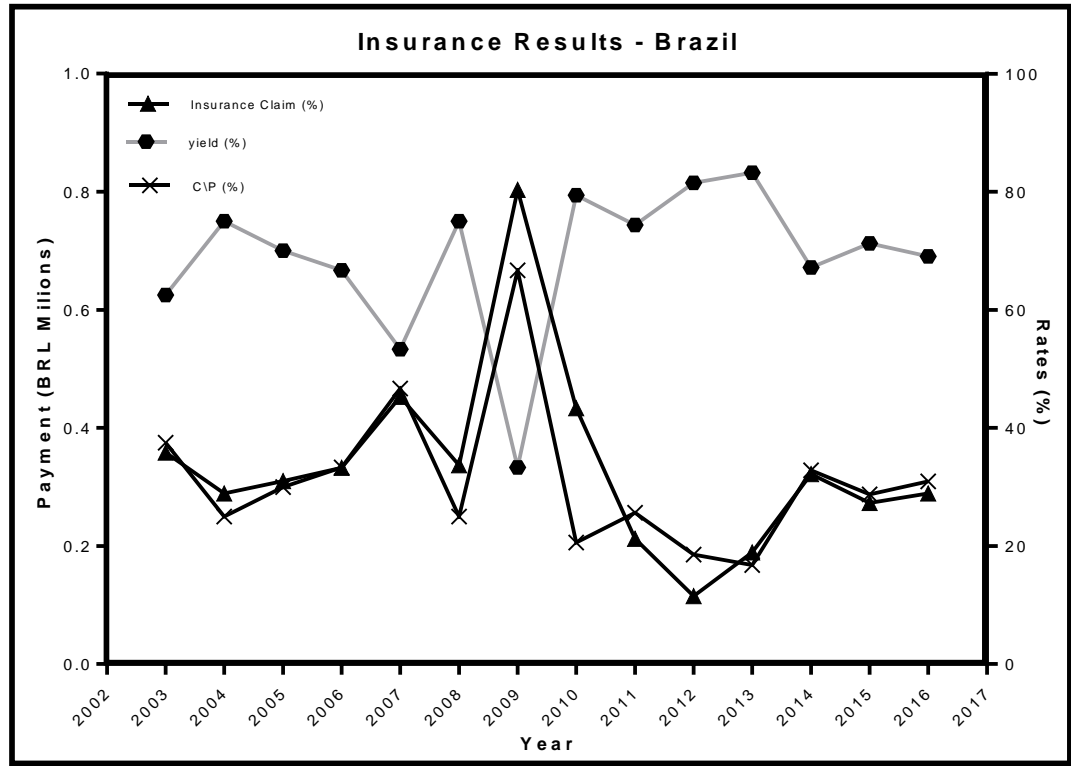

Gráfico 5 - Evolução de Prêmios e Sinistros - 2008/2016 Fonte: SUSEP

Analisando-se os prêmios diretos constata-se que o consumo a partir do ano de 2009 dispara vertiginosamente tendo-se aproximadamente o valor de $\mathrm{R} \$ 54.000 .000,00$ 
em 2012, representando o início de maior fluxo de brasileiros no exterior, incluindo-se a Europa onde, em alguns países como França e Espanha, o turista brasileiro encontrase na $3^{\mathrm{a}}$ e $5^{\mathrm{a}}$ colocações $^{19,20}$, respectivamente, no fluxo de turistas visitantes.

Constata-se também que o S/P declina em fluxo inverso aos prêmios diretos tendo-se o maior ponto de divergência no ano de 2009, fase esta de elevação dos preços de seguros viagem (aumento de 63,6\%) devido ao valor de cobertura mínima imposta pelo Tratado de Schengen (30.000 Euros) bem como pela sua obrigatoriedade de aquisição imposta por esta determinação aos turistas estrangeiros ao bloco, incorrendo numa correção em relação aos anos de 2008 e 2009, onde as seguradoras, de certa forma, obtiveram considerável diminuição na lucratividade (Prêmios diretos $\mathrm{R} \$ 15.000 .000,00 \mathrm{X}$ Sinistro direto - $\mathrm{R} \$ 10.000 .000,00)$. Ressalta-se ainda que os seguros adquiridos para viagens à Europa somente são válidos desde que a sede da seguradora pertença aos países membros do Espaço Schengen, constando-se que, conforme o gráfico, grande parte deste montante é transferido para os países europeus.

Nota-se que o sinistro direto mantém-se em fluxo quase que contínuo e reflexo ao aumento no número de viajantes, sendo uma situação característica e intrínseca ao comportamento do viajante de massa que, na maioria das vezes, evita situações de risco em locais desconhecidos, tentando recriar seus hábitos, bem como a duração das viagens dos brasileiros ao exterior é de curta duração, o que incorre na possibilidade de, se ocorrerem problemas de saúde, os mesmos serem diagnosticados somente no país de origem do viajante quando do seu retorno. 
Analisando-se a evolução dos seguros de saúde na Europa, percebe-se que a implantação do Tratado de Schengen traz seus resultados, principalmente pelo viés de obrigatoriedade aos turistas internos, por meio do Visto Schengen, e a obrigatoriedade de seguro viagem aos estrangeiros no ano de 2007 e, mesmo com a diminuição do turismo interno europeu em 2008/2009, ocorre a substituição destes fluxos por turistas estrangeiros, conforme o gráfico 6.

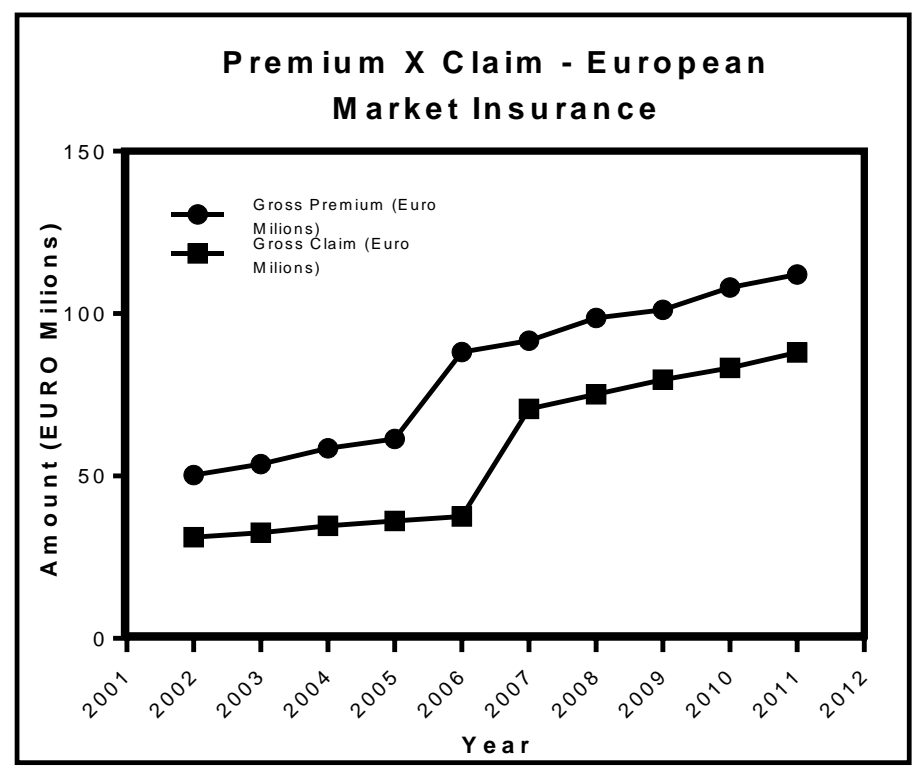

Gráfico 6 - Evolução de Prêmios e Sinistros em Seguro Saúde na Europa Fonte: Insurance Europe ${ }^{21}$

Constata-se ainda que os prêmios brutos, mesmo com a crise financeira da Comunidade Europeia, ainda se mantêm elevados, sem apresentar prejuízo (112.083.000,00 de Euros em 2011), pois o fluxo de capital estrangeiro advindo dos turistas estrangeiros, mantêm o fluxo positivo deste segmento, mesmo com o correlato aumento nos sinistros. 
O "pseudo imposto" criado pela Convenção Schengen assegura assim a continuidade e sobrevivência do mercado de seguros saúde na Europa, mesmo que ocorra uma iminente diminuição de viagens dos BRICs (Brasil, Rússia, Índia, China e África do Sul) pois a imposição do seguro viagem obrigatório aos estrangeiros é uma fonte inesgotável de recursos para manutenção do sistema europeu de saúde.

Um fato não abordado nesta pesquisa refere-se aos casos que demandam uma cobertura maior, isto é, geralmente os turistas optam pela cobertura mínima, tendo-se, nos casos mais severos de internação, a necessidade de complementar os valores gastos do tratamento médico, ocasionando assim a necessidade de pagamento direto por parte do turista que necessita deste serviço. Este volume financeiro não foi medido por esta pesquisa, porém, pode-se constatar que se trata de um montante também considerável e de grande representatividade, conforme reportagens jornalísticas veiculadas nos últimos meses no Brasil ${ }^{22,23}$, gerando assim, maior movimentação financeira na saúde internacional.

Não obstante, a arrecadação total em prêmios de saúde na Europa em 2011, conforme a Insurance Europe ${ }^{24}$, foi de $€ 112$ bilhões sendo pagos $€ 88$ bilhões, o que permite constatar que determinadas medidas adotadas pela área Schengen foram extremamente positivas para o setor de seguro saúde, incluindo-se nesta conta os seguros de viagem, que se tornam uma significativa fonte de recursos.

A maior empresa de seguro da Europa, a Allianz Global Assistance ${ }^{25}$, teve a receita de $€ 993$ milhões no segmento de seguro viagem, representando $44 \%$ do total de faturamento do Grupo, representando um crescimento de 5,1 \% em relação ao ano 
anterior, sendo impulsionado principalmente pelo mercado de turismo B2C (modalidade onde a empresa vende diretamente ao Consumidor).

O mercado global de seguro viagem, conforme estimativa da Finaccord ${ }^{26}$ foi de USD 11,9 bilhões, com a venda de 200 milhões de apólices, sendo esperado que ocorra um crescimento para USD 14,7 bilhões com 243 milhões de apólices em 2016.

Conforme os números apresentados, constatamos a lucratividade do segmento, e principalmente, o resultado das medidas adotadas com a implantação do tratado Schengen, uma vez que o crescimento de receita tem sido expressivo a cada ano desde a sua criação.

O Brasil, sendo um país de dimensões continentais, deveria adotar medidas semelhantes as da área Schengen no intuito de, em primeiro lugar redistribuir os gastos realizados internamente com o Serviço Único de Saúde - SUS, pois existe uma intensa migração de pessoas em busca de serviços especializados, onerando assim os estados que possuem centros de medicina de ponta. Outra questão importante relaciona-se ao fato de que não há uma obrigatoriedade ao turista interno, e, principalmente, para o turista estrangeiro quanto à necessidade do seguro viagem, o que pode ocasionar um gasto excessivo se ocorrerem situações de gravidade, como surtos e epidemias, nos grandes eventos de massa que serão sediados pelo país. O custo em si de uma situação como esta poderia gerar um colapso do sistema de saúde, uma vez que os custos seriam direcionados imediatamente ao sistema público de saúde brasileiro. A imposição do seguro viagem para os turistas estrangeiros poderia significar uma 
reserva financeira interessante, bem como uma fonte de recurso alternativo para o setor de saúde pública brasileira.

O aumento de exposição de países emergentes no cenário internacional de viagens gera novas questões a serem incorporadas em suas políticas públicas para viajantes sendo necessário criar novos sistemas conjuntos de ações que promovam a continuidade dos fluxos de viagens. 


\section{OBJETIVOS}

\section{Objetivo Geral}

Analisar uma política de amplo espectro voltada para a segurança de áreas receptoras e viajantes (Convenção Schengen), bem como a proposição de medidas protetivas a serem implementadas em países emergentes, com foco no Brasil, em virtude de sua crescente participação no cenário internacional de viagens, e concomitante fragilidade para importação e exportação de doenças infecciosas.

\section{Objetivos Específicos}

1. Analisar uma medida protetiva ampla de países com atividade turística consolidada (Convenção Schengen);

2. Verificar e analisar os dados de consumo de seguro viagem de brasileiros após a implantação da Convenção Schengen;

3. Analisar a condição de saúde do brasileiro que realiza viagens internacionais por meio do sinistro de seguro viagem e de atendimento pré e pós viagem em órgão competente;

4. Levantar alguns riscos potenciais em virtude de nossa crescente participação no cenário internacional de viagens; 
5. Identificar medidas protetivas adotadas no Brasil bem como propor algumas estratégias que visem à segurança e bem-estar do viajante brasileiro. 


\section{MATERIAIS E MÉTODOS}

Este item é composto por informações sobre o processo de estruturação desta pesquisa desde as informações de ordem legal, como o registro no comitê de ética, até os procedimentos metodológicos adotados para cada um dos manuscritos resultantes, incluindo-se os passos realizados e meios de decisão para coleta, seleção e descarte de dados.

\subsection{COMITÊ DE ÉTICA}

Os estudos e pesquisas apresentados nesta tese foram aprovados e possuem anuência do Comitê de Ética da Faculdade de Medicina da Universidade de São Paulo - Hospital das Clínicas - Processo: CAAE 22239713.0.0000.0065 - Relatório Técnico No 743.367 de 23 de julho de 2014.

\subsection{MANUSCRITO I}

Por se tratar da fase introdutória onde houve a necessidade de construir a fase conceitual desta tese, esta etapa foi estruturada em 3 momentos, sendo o primeiro referente à compreensão da Convenção Schengen e suas diretrizes tendo-se a necessidade de realizar uma revisão bibliográfica desta normativa para entender os seus desdobramentos nos países membros da União Europeia, bem como analisar a importância do Turismo como atividade econômica para a comunidade, sendo o volume de turismo interno utilizado como parâmetro no intervalo de 2005 a 2011, para 
compreendermos os efeitos causados em virtude da implantação desta nova política para os fluxos internacionais de viagem. Estes materiais secundários foram coletados nos arquivos eletrônicos do Parlamento Europeu e no órgão de estatística oficial da União Europeia ${ }^{6}$.

A segunda etapa deste item foi construída com a coleta de informações de volume de viajantes brasileiros recebidos, sendo o primeiro colocado no ranking os Estados Unidos. As seleções dos dois principais países receptores europeus para realizarmos um estudo comparativo, em vista da proposta inicial, culminaram na França e Espanha pelo volume de turistas brasileiros recebidos no período de 2002 a 2012, sendo este o método de triagem e seleção. Os dados foram obtidos com base nos relatórios da Organização Mundial do Turismo e da consultoria independente Euromonitor, sendo confirmados por pesquisa direta (entrevista) junto aos órgãos de fomento de Turismo destes países.

A terceira etapa, e mais importante em virtude de se poder analisar a eficácia da Convenção Schengen foi obtida junto aos relatórios de produtividade do segmento de Seguro de Viagem, sendo utilizados os dados dos órgãos de fiscalização do segmento de seguros privados, tendo-se a INSURANCE EUROPE e a SUSEP como fontes principais, além dos balanços anuais das companhias de seguro europeias, sendo selecionada a Allianz Assistance Group devido ao fato de ter a maior lucratividade dentro do segmento na Europa.

\subsection{MANUSCRITO II}


Os dados secundários utilizados para elaboração deste item foram obtidos de bases dados públicos como Tabnet (Informações de Saúde) do SUS - Ministério da Saúde - MS/Brasil, para informações sobre casos confirmados de Dengue e Zika Vírus no ano de 2015. Os dados públicos referentes aos fluxos de viajantes no período de 2013 a 2014 foram obtidos junto ao site do Ministério do Turismo/Brasil.

\subsection{MANUSCRITO III}

O estudo ecológico foi realizado por meio de revisão sistemática dos casos confirmados de sarampo no período de 2014/2015 com dados obtidos na Base Nacional de Saúde (BNS) - Serviço de Vigilância em Saúde/Ministério da Saúde e no Sistema de Informação de Agravos de Notificação - SINAN Net. Uma correlação entre a origem das fontes de focos e o fenômeno dos viajantes foi obtida por meio de relatórios epidemiológicos do Centro de Vigilância Epidemiológica Prof. Alexandre Vranjac - CVE/SP. As propostas de prevenção e proteção são formuladas por meio do mapeamento global realizado pela Organização Mundial de Saúde - OMS, em combinação com ações e campanhas usuais do Ministério da Saúde do Brasil.

\subsection{MANUSCRITO IV}

Analisamos os dados de ocorrência por meio do Boletim Epidemiológico Paulista da Secretaria de Saúde do Governo do Estado de São Paulo para os casos de Leishmaniose Visceral, realizando um estudo transversal no estado de São Paulo para as Cidades com Alertas para a doença $(n=123)$ e a existência de estabelecimentos "Pet Friendly", que recebem visitantes e seus animais de estimação no estado de São Paulo ( $\mathrm{n}=57)$ no início de 2016. 


\subsection{MANUSCRITO V}

Analisamos o aumento dos viajantes internacionais que visitam áreas naturais no Brasil por meio de dados públicos obtidos em relatórios de chegadas de turistas estrangeiros do Ministério do Turismo/Brasil no ano de 2016. Os dados referentes aos surtos localizados na região da Chapada Diamantina para o mesmo ano foram obtidos em mídia aberta e depois confrontados com os dados do Tabnet SUS/MS/Brasil, demonstrando o potencial de atividades de lazer junto às áreas naturais como fator preocupante para a importação/exportação de doenças infecciosas.

\subsection{MANUSCRITO VI}

No último manuscrito, realizamos um estudo retrospectivo de consultas em uma Clínica Pública de Medicina do Viajante no período de 2012 a 2016. O Ambulatório dos Viajantes - FMUSP/HC foi selecionado por oferecer assistência gratuita que permitiria hipoteticamente o acesso a um maior número de pacientes espontâneos. Em 2016, analisamos a triagem de consultas por gênero, distribuição de idade de acordo com as condições de limitação para viajar (0-18 anos - viajante menor de idade / 18-30 - Jovem Adulto / 30-45 anos - Adulto / Mais de 45 anos Sénior) e destinos de viagem. No mesmo ano, desenvolvemos um estudo qualitativo das principais causas que afetaram os viajantes por meio de consulta pós-viagem. O objetivo desta etapa final foi corroborar a teoria de que o viajante brasileiro possui boa condição de saúde, bem como para demonstrar que o mesmo está mais consciente quanto aos aspectos de segurança e saúde em relação ao fenômeno das 
viagens, além de nossas ações setorizadas, como o controle vacinal realizado por esta clínica e de certa forma adotada também pelos demais ambulatórios públicos, sendo eficazes na prevenção de doenças conforme dados de pré e pós consulta. 


\section{RESULTADOS E DISCUSSÃO}

Neste capítulo apresentaremos os principais dados coletados, bem como a discussão de sua relevância para compreensão da necessidade de composição de uma política pública voltada para a proteção de nações e seus viajantes principalmente de países emergentes (como o Brasil) que representam metade do fluxo internacional de viagens.

\subsection{A RÁPIDA TRANSMISSÃO DE DOENÇAS INFECCIOSAS NO MUNDO - UMA NOVA QUESTÃO PARA A SAÚDE PÚBLICA}

O número elevado de pessoas que viajam ao redor do mundo (1.184.000.000 de viagens em 2015) tem participação de $~ 45 \%$ de turistas oriundos de países emergentes que, no contexto atual, sediam eventos esportivos de massa internacionais (Gráfico 7 A/B), aumentando o risco potencial para a importação de doenças infecciosas devido aos países emergentes terem recentemente alterado os seus sistemas de saúde pública, que ainda são dedicados às doenças endêmicas locais, aprimorando-se ainda para esta nova política e realidade oriunda do fenômeno de viagens nacionais e internacionais ${ }^{27}$. 


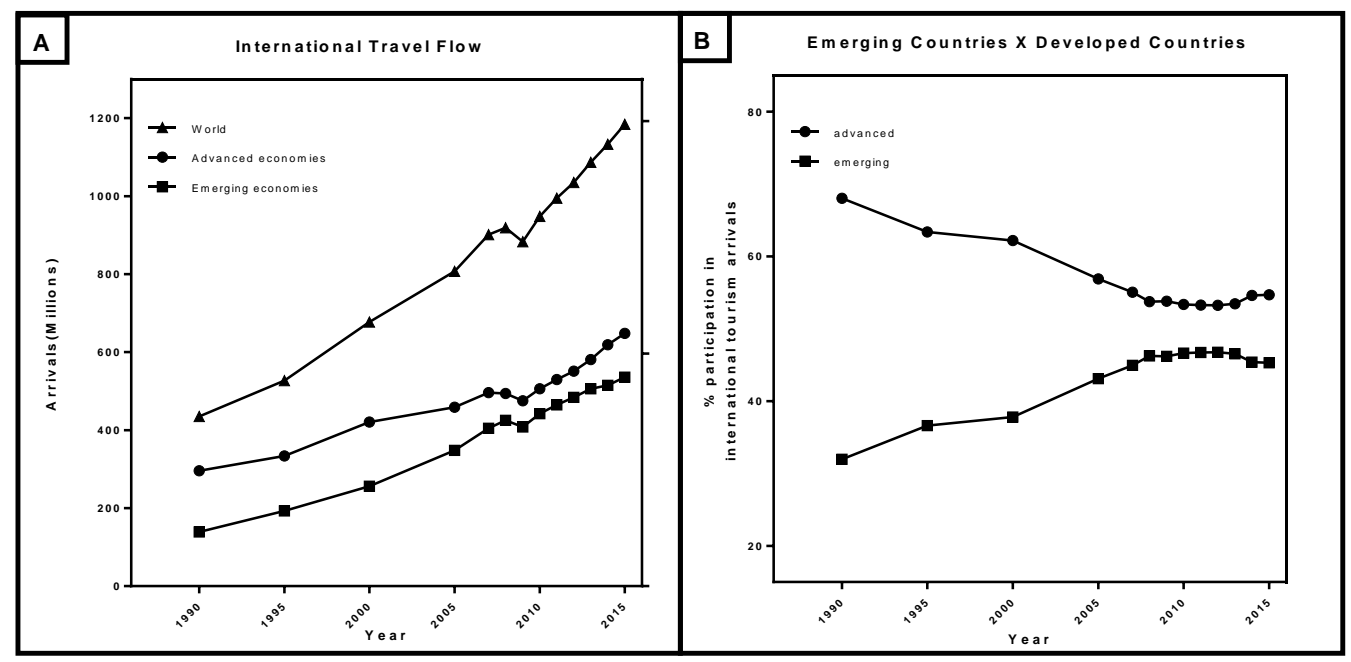

Gráfico 7 - Fluxos Internacionais de Viagem

Os viajantes internacionais de países emergentes como o Brasil, parecem ser distintos da maioria dos países com maior tradição de viagem, possuindo maior status social e melhor saúde, fatos demonstrados pelas suas altas despesas de viagem bem como pela baixa de seguro viagem (Gráficos. 8 e 9), corroborando a teoria de serem “imigrantes saudáveis"28.

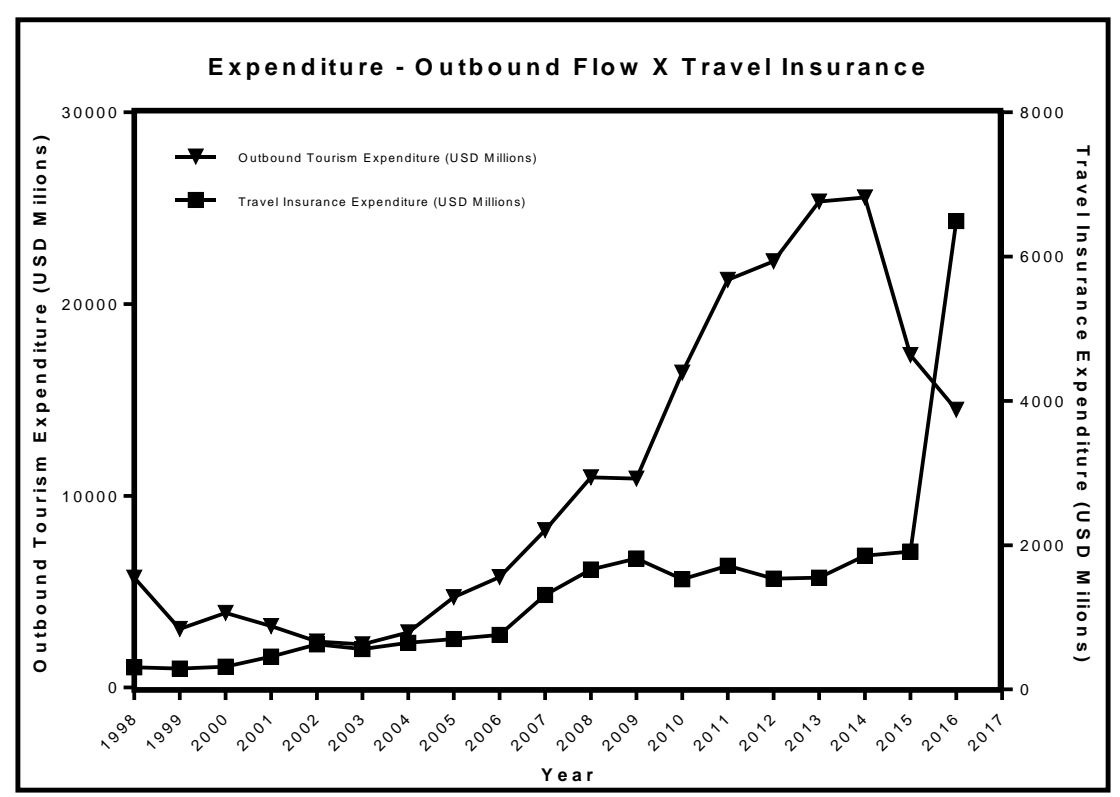

Gráfico 8 - Fluxo Internacional de Turistas Brasileiros X Gastos com Seguro 
As doenças infecciosas importadas representam um novo problema para esses viajantes internacionais, onde vemos surtos causados por pessoas que visitam áreas endêmicas ou com risco potencial, incluindo países desenvolvidos, e importando doenças controladas previamente, como o Sarampo e a Caxumba no Brasil $2014 / 2015^{29}$.

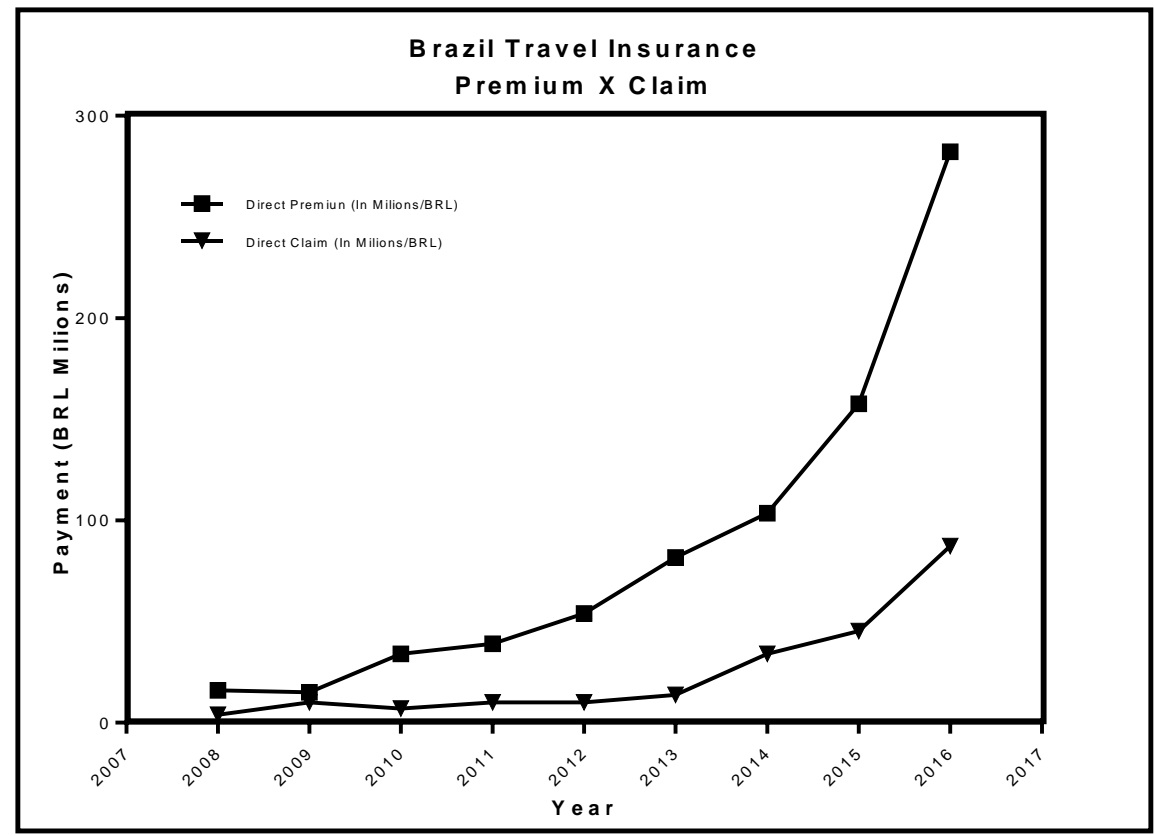

Gráfico 9 - O Consumo de Seguro Viagem no Brasil - Prêmios X Sinistros

O controle de doenças infecciosas imposto por algumas nações, devido ao aumento das viagens, conduz a repensar a saúde pública como um fenômeno maior, onde os modelos atuais de vigilância das fronteiras, seja por visto de entrada, duração limitada de permanência ou seguro de viagem obrigatório (Convenção de Schengen), não parecem tão efetivos na prevenção da migração de doenças infecciosas transportadas tanto por visitantes estrangeiros como por viajantes que retornam, como por exemplo, a recente epidemia do vírus Zika no Brasil e sua rápida disseminação 
mundial, possivelmente uma pandemia em larga escala que promoveu uma mobilização global para controlar e estudar uma nova doença emergente ${ }^{30}$, denotando a discussão de um tema importante: as doenças infecciosas não se limitam mais às fronteiras governamentais ou às nações pobres, são um problema mundial, especialmente as doenças negligenciadas.

Os países emergentes com sistemas de saúde pública recentemente estabelecidos estão expostos a novos surtos de doenças devido ao recente aumento de viagens internacionais, exigindo novas medidas preventivas tanto para a vigilância das fronteiras quanto para o controle de seus viajantes que retornam, sendo um desafio para os sistemas dedicados às doenças endêmicas. A implementação integral do Regulamento Sanitário Internacional da Organização Mundial de Saúde - 2005, que estabelece o Certificado Internacional de Vacinação e Profilaxia, seria recomendado também para os países desenvolvidos, sendo necessária sua revisão para incluir os sistemas emergentes recém estabelecidos, no intuito de se controlar as doenças preveníveis por vacina que estão sendo transferidas de países desenvolvidos ${ }^{31}$. O seguro de viagem representa uma ferramenta importante devido à possibilidade de o viajante receber tratamento médico que evita a potencial transferência de doença infecciosa ao seu país de origem.

Acreditamos ser necessária a criação de uma rede global única para melhorar a notificação de doenças transmissíveis ou desconhecidas, onde todos devem adotar protocolos rígidos para fornecer informações sobre surtos novos ou atuais. Estes dados devem estar disponíveis para todas as nações, para que os sistemas públicos de saúde 
em todo o mundo tenham acesso irrestrito para estes alertas de surtos de forma unificada. Provavelmente, poderíamos enfrentar outras epidemias de vírus H1N1, Ebola e Zika de forma mais eficaz do que o modelo atual, e talvez os pesquisadores possam beneficiar suas instituições para coletar informações para suas pesquisas e, finalmente, ajudar as autoridades de saúde a prevenir algumas outras epidemias que estão por vir e acelerar o tratamento destes doentes.

A questão essencial refere-se à qualidade de saúde do turista, considerado como o viajante de curta permanência, enquanto que os demais migrantes e refugiados tem status de saúde completamente diferente. A visão integrada do turista como os demais migrantes levou ao comportamento restritivo da convenção Schengen, mostrando a necessidade de reconhecimento do turista como um novo modelo de viajante e que medidas restritivas a todos os viajantes afetam o fluxo de capitais entre os países derivados do turismo, sem os imaginários riscos de saúde e custos indiretos. Na realidade, o turista é um cidadão global saudável, pertencente a um grupo social diferenciado com boa saúde e que tem demandas de lazer e prazer especificas dentro de uma nova demanda cosmopolita.

\subsection{ROTAS DE ENTRADA PARA O VÍRUS ZIKA NO BRASIL APÓS A COPA DO MUNDO DE 2014: NOVAS POSSIBILIDADES}

No início de 2015, vários casos de infecções pelos vírus da Dengue e da Chikungunya foram relatados no Brasil ${ }^{32}$. As epidemias de dengue estão localizadas nos estados de São Paulo (637029 casos confirmados), Minas Gerais (166360 casos 
confirmados), Goiás (121501 casos confirmados), Pernambuco (68510 casos confirmados), Ceará (59074 casos confirmados), Rio de Janeiro (49480 casos confirmados), Paraná (46694 casos confirmados), Bahia (42476 casos confirmados), Rio Grande do Norte (21194 casos confirmados), Mato Grosso do Sul (18663 casos confirmados), Paraíba (18018 casos confirmados), Espírito Santo (16477 confirmados casos), Alagoas 13846 casos confirmados) e Mato Grosso (13700 casos confirmados). Para a infecção do vírus Chikungunya, o estado da Bahia aparece como o primeiro em número de casos confirmados (7820), seguido do Amapá (1070) e do Distrito Federal (194).

As infecções por Zika Vírus apresentaram quadro clínico muito semelhante ao da Dengue e o número de casos relatados oficialmente é baixo, devido a problemas de detecção principalmente devido à alta prevalência do vírus da dengue em determinadas áreas e a co-infecção por estes vírus não ser incomum ${ }^{33}$. A hipótese mais forte para a introdução do vírus Zika no Brasil seria por viajantes africanos durante a Copa do Mundo de 2014 com transmissão de vírus por pacientes assintomáticos, subsidiada pelo aumento significativo de $132 \%$ no fluxo de turistas internacionais (junho/2014 em relação a junho/2013) para o país.

Mas o vírus circulante no Brasil foi identificado como genótipo asiático por meio de análises filogenéticas da região do envelope nos dois casos do estado da Bahia, área com maior número de casos confirmados ${ }^{34}$, e devido ao genótipo de Zika encontrado, novas rotas alternativas para entrada externa deveriam ser estudadas, permitindo uma melhor compreensão da circulação do vírus no país. 
Verificamos o número de viajantes recebidos no Brasil (Tabela 1) das regiões endêmicas do Zika Vírus à época (África, Ásia, Ilhas do Pacífico e Chile - Figura 1) procurando aqueles que apresentariam maior potencial para transportar a cepa asiática do Zika Vírus. 
Table 1 - Inbound tourism in Brazil from endemic areas

\begin{tabular}{|c|c|c|c|c|c|c|c|c|c|c|c|c|c|c|c|c|c|c|c|c|c|c|c|c|c|c|c|c|}
\hline \multicolumn{29}{|c|}{ Africa* } \\
\hline & $\begin{array}{c}\text { AM } \\
2013 \\
\end{array}$ & $\begin{array}{c}\text { AM } \\
2014 \\
\end{array}$ & $\begin{array}{c}\text { BA } \\
2013 \\
\end{array}$ & $\begin{array}{r}\text { BA } \\
2014 \\
\end{array}$ & $\begin{array}{c}\mathrm{CE} \\
2013 \\
\end{array}$ & $\begin{array}{c}\mathrm{CE} \\
2014 \\
\end{array}$ & $\begin{array}{c}\text { DF } \\
2013 \\
\end{array}$ & $\begin{array}{c}\text { DF } \\
2014 \\
\end{array}$ & $\begin{array}{c}\text { MS } \\
2013 \\
\end{array}$ & $\begin{array}{r}\text { MS } \\
2014 \\
\end{array}$ & $\begin{array}{c}\text { MG } \\
2013 \\
\end{array}$ & $\begin{array}{r}\text { MG } \\
2014 \\
\end{array}$ & $\begin{array}{r}P A \\
2013 \\
\end{array}$ & $\begin{array}{r}\text { PA } \\
201 \\
\end{array}$ & $\begin{array}{r}\text { PR } \\
2013 \\
\end{array}$ & $\begin{array}{c}\text { PR } \\
2014 \\
\end{array}$ & $\begin{array}{c}\mathrm{PE} \\
2013 \\
\end{array}$ & $\begin{array}{c}\mathrm{PE} \\
2014 \\
\end{array}$ & $\begin{array}{r}\mathrm{RN} \\
2013 \\
\end{array}$ & $\begin{array}{c}\mathrm{RN} \\
2014 \\
\end{array}$ & $\begin{array}{c}\text { RS } \\
2013 \\
\end{array}$ & $\begin{array}{c}\text { RS } \\
2014 \\
\end{array}$ & $\begin{array}{c}\mathrm{RJ} \\
2013 \\
\end{array}$ & $\begin{array}{c}\mathrm{RJ} \\
2014 \\
\end{array}$ & $\begin{array}{c}\mathrm{SC} \\
2013 \\
\end{array}$ & $\begin{array}{c}\mathrm{SC} \\
2014 \\
\end{array}$ & $\begin{array}{c}\text { SP } \\
2013 \\
\end{array}$ & $\begin{array}{c}\text { SP } \\
2014 \\
\end{array}$ \\
\hline JAN & 3 & 2 & 13 & 13 & 79 & 68 & 17 & 6 & 3 & 1 & 10 & 7 & 3 & 3 & 18 & 30 & 8 & 10 & 0 & 0 & 29 & 13 & 355 & 412 & 5 & 5 & 1.227 & 915 \\
\hline FEB & 3 & 1 & 24 & 17 & 36 & 42 & 13 & 30 & 2 & 4 & 6 & 7 & 0 & 0 & 28 & 35 & 1 & 6 & 3 & 2 & 9 & 1 & 393 & 556 & 16 & 3 & 1.033 & 1.173 \\
\hline MAR & 1 & 2 & 20 & 12 & 49 & 21 & 39 & 37 & 1 & 0 & 1 & 1 & 0 & 0 & 17 & 30 & 13 & 6 & 1 & 0 & 25 & 2 & 458 & 558 & 14 & 5 & 1.247 & 1.002 \\
\hline APR & 1 & 0 & 13 & 42 & 43 & 34 & 47 & 64 & 6 & 1 & 7 & 3 & 0 & 0 & 22 & 29 & 5 & 20 & 0 & 0 & 12 & 4 & 329 & 343 & 3 & 2 & 1.292 & 1.473 \\
\hline MAY & 3 & 1 & 71 & 18 & 93 & 39 & 160 & 24 & 0 & 0 & 10 & 9 & 0 & 0 & 30 & 7 & 29 & 9 & 0 & 0 & 33 & 11 & 298 & 521 & 1 & 0 & 1.768 & 1.596 \\
\hline JUN & 0 & 0 & 15 & 181 & 76 & 102 & 34 & 316 & 0 & 0 & 17 & 2770 & 0 & 0 & 23 & 62 & 23 & 18 & 1 & 790 & 37 & 0 & 348 & 2638 & 0 & 0 & 1.568 & 7.646 \\
\hline \multicolumn{29}{|c|}{ Asia $^{\star *}$} \\
\hline & $\begin{array}{c}\mathrm{AM} \\
2013 \\
\end{array}$ & $\begin{array}{c}\text { AM } \\
2014 \\
\end{array}$ & $\begin{array}{c}\text { BA } \\
2013 \\
\end{array}$ & $\begin{array}{c}\text { BA } \\
2014 \\
\end{array}$ & $\begin{array}{c}\text { CE } \\
2013 \\
\end{array}$ & $\begin{array}{c}\mathrm{CE} \\
2014 \\
\end{array}$ & $\begin{array}{c}\mathrm{DF} \\
2013 \\
\end{array}$ & $\begin{array}{c}\text { DF } \\
2014 \\
\end{array}$ & $\begin{array}{c}\text { MS } \\
2013 \\
\end{array}$ & $\begin{array}{c}\text { MS } \\
2014 \\
\end{array}$ & $\begin{array}{c}M G \\
2013 \\
\end{array}$ & $\begin{array}{c}M G \\
2014 \\
\end{array}$ & $\begin{array}{r}\text { PA } \\
2013 \\
\end{array}$ & $\begin{array}{r}P A \\
201 \\
\end{array}$ & $\begin{array}{r}\text { PR } \\
2013 \\
\end{array}$ & $\begin{array}{c}\text { PR } \\
2014 \\
\end{array}$ & $\begin{array}{c}\mathrm{PE} \\
2013 \\
\end{array}$ & $\begin{array}{c}\mathrm{PE} \\
2014 \\
\end{array}$ & $\begin{array}{r}\mathrm{RN} \\
2013 \\
\end{array}$ & $\begin{array}{c}\mathrm{RN} \\
2014 \\
\end{array}$ & $\begin{array}{c}\text { RS } \\
\text { 2013 } \\
\end{array}$ & $\begin{array}{c}\text { RS } \\
2014 \\
\end{array}$ & $\begin{array}{c}\mathrm{RJ} \\
2013 \\
\end{array}$ & $\begin{array}{c}\mathrm{RJ} \\
2014 \\
\end{array}$ & $\begin{array}{c}\mathrm{SC} \\
2013 \\
\end{array}$ & $\begin{array}{c}\text { SC } \\
2014 \\
\end{array}$ & $\begin{array}{c}\text { SP } \\
2013 \\
\end{array}$ & $\begin{array}{c}\text { SP } \\
2014 \\
\end{array}$ \\
\hline JAN & 22 & 23 & 14 & 13 & 7 & 6 & 23 & 13 & 14 & 8 & 2 & 6 & 1 & 0 & 236 & 258 & 21 & 6 & 5 & 6 & 35 & 22 & 882 & 1182 & 20 & 10 & 3057 & 2143 \\
\hline FEB & 23 & 20 & 29 & 18 & 51 & 5 & 31 & 27 & 4 & 3 & 6 & 10 & 3 & 3 & 876 & 387 & 8 & 14 & 1 & 0 & 6 & 14 & 1900 & 1826 & 59 & 9 & 3836 & 3222 \\
\hline MAR & 39 & 37 & 17 & 33 & 1 & 1 & 24 & 25 & 17 & 7 & 23 & 9 & 8 & 2 & 383 & 686 & 13 & 22 & 3 & 0 & 25 & 22 & 1720 & 1998 & 26 & 0 & 4460 & 2888 \\
\hline APR & 94 & 26 & 15 & 15 & 11 & 4 & 26 & 107 & 7 & 3 & 2 & 7 & 2 & 0 & 406 & 442 & 12 & 23 & 1 & 0 & 52 & 12 & 1784 & 1653 & 24 & 0 & 4150 & 4654 \\
\hline MAY & 66 & 30 & 25 & 14 & 5 & 4 & 35 & 71 & 10 & 7 & 21 & 7 & 2 & 4 & 340 & 470 & 20 & 32 & 0 & 0 & 20 & 21 & 1793 & 2374 & 35 & 0 & 4317 & 4695 \\
\hline JUN & 28 & 112 & 13 & 129 & 9 & 29 & 27 & 269 & 1 & 4 & 26 & 80 & 7 & 0 & 257 & 444 & 43 & 54 & 0 & 0 & 35 & 253 & 1288 & 6549 & 6 & 1 & 4175 & 12048 \\
\hline \multicolumn{29}{|c|}{ Chile } \\
\hline & $\begin{array}{c}\text { AM } \\
2013\end{array}$ & $\begin{array}{l}\text { AM } \\
2014\end{array}$ & $\begin{array}{c}\mathrm{BA} \\
2013\end{array}$ & $\begin{array}{c}B A \\
2014\end{array}$ & $\begin{array}{c}\mathrm{CE} \\
2013\end{array}$ & $\begin{array}{c}\mathrm{CE} \\
2014 \\
\end{array}$ & $\begin{array}{c}\mathrm{DF} \\
2013\end{array}$ & $\begin{array}{c}\text { DF } \\
2014\end{array}$ & $\begin{array}{l}\text { MS } \\
2013\end{array}$ & $\begin{array}{c}\text { MS } \\
2014\end{array}$ & $\begin{array}{l}\text { MG } \\
2013\end{array}$ & $\begin{array}{l}\text { MG } \\
2014\end{array}$ & $\begin{array}{c}\text { PA } \\
2013\end{array}$ & $\begin{array}{l}\begin{array}{r}P A \\
201\end{array} \\
\end{array}$ & $\begin{array}{c}P R \\
2013 \\
\end{array}$ & $\begin{array}{c}\text { PR } \\
2014\end{array}$ & $\begin{array}{c}\mathrm{PE} \\
2013\end{array}$ & $\begin{array}{c}\mathrm{PE} \\
2014\end{array}$ & $\begin{array}{c}\mathrm{RN} \\
2013\end{array}$ & $\begin{array}{c}\mathrm{RN} \\
2014\end{array}$ & $\begin{array}{c}\text { RS } \\
2013\end{array}$ & $\begin{array}{c}\text { RS } \\
2014\end{array}$ & $\begin{array}{c}\text { RJ } \\
2013\end{array}$ & $\begin{array}{c}\mathrm{RJ} \\
2014\end{array}$ & $\begin{array}{c}S C \\
2013\end{array}$ & $\begin{array}{c}\text { SC } \\
2014\end{array}$ & $\begin{array}{c}\mathrm{SP} \\
2013\end{array}$ & $\begin{array}{c}\text { SP } \\
2014\end{array}$ \\
\hline JAN & 9 & 1 & 18 & 7 & 0 & 0 & 4 & 18 & 37 & 99 & 1 & 2 & 6 & 9 & 3191 & 4595 & 3 & 6 & 0 & 0 & 1756 & 327 & 7782 & 10952 & 6132 & 5486 & 12584 & 8067 \\
\hline FEB & 1 & 0 & 16 & 1 & 3 & 2 & 8 & 6 & 79 & 76 & 3 & 49 & 5 & 3 & 2618 & 2890 & 5 & 6 & 0 & 0 & 527 & 245 & 11498 & 13865 & 9364 & 7140 & 20384 & 16874 \\
\hline MAR & 5 & 1 & 11 & 4 & 6 & 0 & 17 & 14 & 21 & 23 & 4 & 4 & 0 & 0 & 716 & 412 & 15 & 2 & 0 & 0 & 250 & 152 & 9200 & 4264 & 98 & 89 & 11849 & 5938 \\
\hline APR & 1 & 2 & 4 & 78 & 3 & 0 & 8 & 27 & 9 & 33 & 67 & 5 & 2 & 2 & 493 & 375 & 6 & 0 & 0 & 0 & 1446 & 333 & 5485 & 4723 & 11 & 120 & 8336 & 8178 \\
\hline MAY & 1 & 2 & 6 & 73 & 3 & 3 & 13 & 11 & 10 & 50 & 3 & 10 & 0 & 0 & 395 & 431 & 10 & 1 & 1 & 0 & 1572 & 589 & 5657 & 5294 & 7 & 7 & 9202 & 8289 \\
\hline \multirow[t]{2}{*}{ JUN } & 1 & 18 & 1 & 1676 & 1 & 2 & 14 & 133 & 21 & 1195 & 13 & 547 & 2 & 2 & 469 & 4622 & 6 & 11 & 0 & 0 & 1145 & 25628 & 4451 & 17617 & 6 & 136 & 7551 & 24599 \\
\hline & AFRICA & ASIA & CHILE & $\begin{array}{r}\text { BY AIR } \\
\text { AFRICA } \\
\end{array}$ & $\begin{array}{c}\text { BY AIR } \\
\text { ASIA } \\
\end{array}$ & $\begin{array}{l}\text { BY AIR } \\
\text { CHILE } \\
\end{array}$ & $\begin{array}{l}\text { BY SEA } \\
\text { AFRICA } \\
\end{array}$ & $\begin{array}{l}\text { BY } \\
\text { SEA } \\
\text { ASIA }\end{array}$ & $\begin{array}{c}\text { BY SEA } \\
\text { CHILE } \\
\end{array}$ & $\begin{array}{c}\text { BY } \\
\text { LAND } \\
\text { AFRICA }\end{array}$ & \begin{tabular}{|c|c|} 
BY \\
LAND \\
ASIA
\end{tabular} & $\begin{array}{c}\text { BY } \\
\text { LAND } \\
\text { CHILE } \\
\end{array}$ & \multicolumn{2}{|c|}{\begin{tabular}{c|} 
BY \\
RIVER \\
AFRICA
\end{tabular}} & \multicolumn{2}{|r|}{$\begin{array}{l}\text { BY } \\
\text { RIVER } \\
\text { CHILE } \\
\end{array}$} & & & & & & & & & & & & \\
\hline 2013 & 27957 & 76166 & 268203 & 27341 & 70991 & 236530 & 92 & 845 & 907 & 502 & 4296 & 30706 & \multicolumn{2}{|c|}{22} & \multicolumn{2}{|r|}{60} & & & & & & & & & & & & \\
\hline 2014 & 42131 & 101585 & 336950 & 41613 & 96504 & 278113 & 55 & 212 & 812 & 424 & 4778 & 57995 & \multicolumn{2}{|c|}{39} & \multicolumn{2}{|r|}{30} & & & & & & & & & & & & \\
\hline
\end{tabular}

* AFRICA (Not Included: South Africa, Angola, Cabo Verde and Nigeria)

** ASIA (Not Included: China, Japan, Israel and

$$
\text { Korea) }
$$

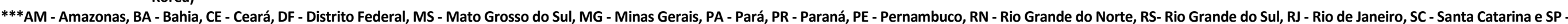
São Paulo 
Encontramos um número maior de turistas asiáticos nesse período em comparação aos poucos africanos por vários estados, bem como a proximidade do país com o Chile, que no período em torno da Copa do Mundo de 2014 apresentou casos confirmados de Zika na Ilha de Páscoa, cuja filogenia foi detectada como a cepa asiática $^{35}$. O fluxo doméstico é outra possibilidade plausível porque as cidades hospedeiras dos jogos estavam localizadas em vários estados, exigindo o movimento de viajantes estrangeiros e domésticos entre esses locais (São Paulo - SP, Rio de Janeiro - RJ, Salvador - BA Natal - RN, Cuiabá - MT, Belo Horizonte - MG, Fortaleza - CE, Recife - PE, Manaus - AM, Brasília - DF, Porto Alegre - RS e Curitiba - PR).

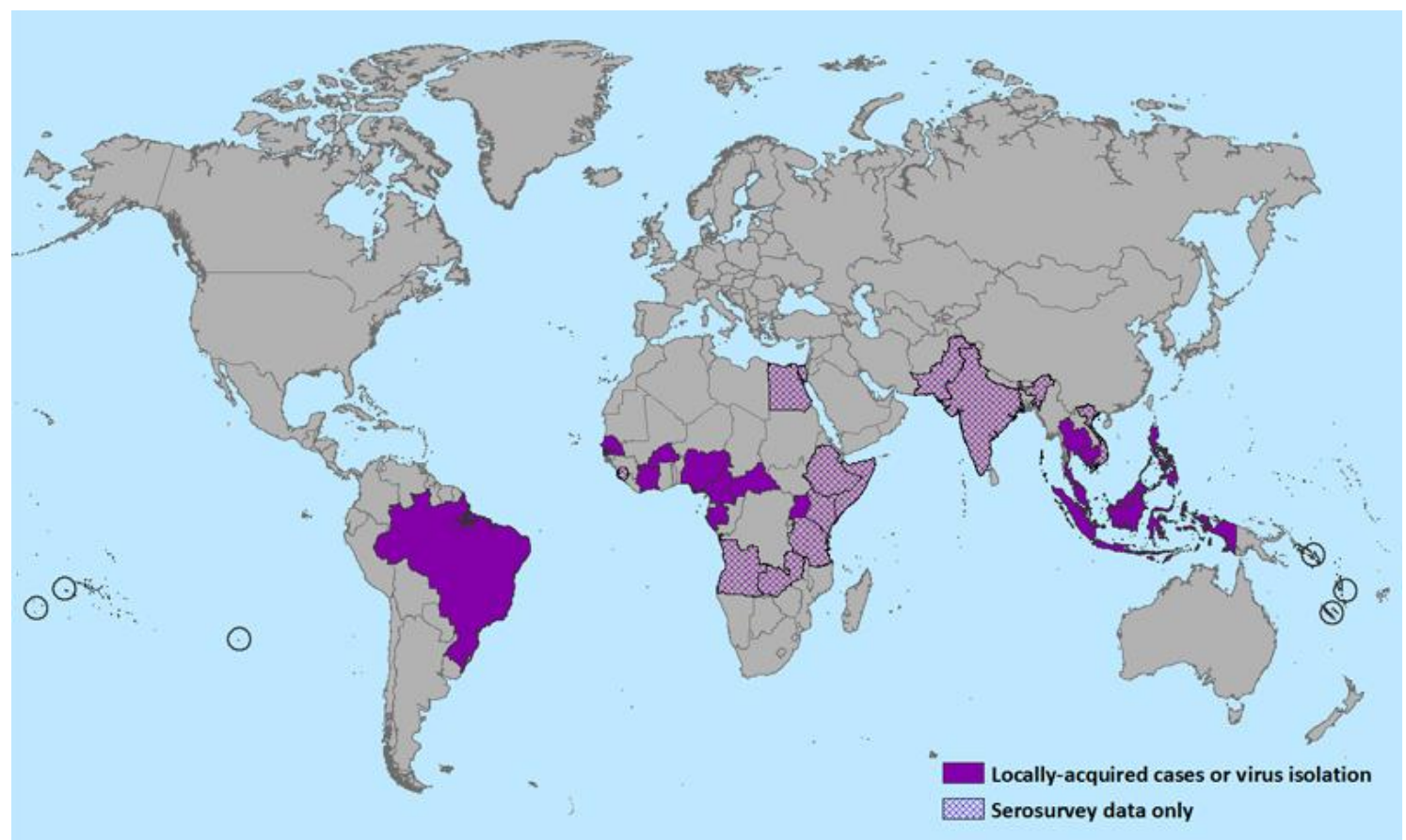

Figura 1 - CDC - Países com Evidência Passada ou Atual de Transmissão de Zika Virus (Maio de 2015) - http://www.cdc.gov/zika/geo/index.html

O desenvolvimento de novos estudos torna-se necessário para proporcionar mais controle e supervisão das fronteiras devido ao aumento exponencial de viajantes 
estrangeiros para o país. O cenário atual do surto de Zika no Brasil e a detecção de sua rota de entrada e propagação no país sugerem novas medidas de saúde pública para os viajantes.

Há um potencial risco para a transferência de agentes infecciosos nos eventos de massa, porém, tal questão não é tratada adequadamente pelos gestores do ponto de vista sanitário, sendo manejada de forma superficial, o que pode permitir a transmissão de doenças. Esta é uma condição restritiva e impeditiva para a realização adequada de eventos de massa. $\mathrm{O}$ balanço entre riscos de ordem geral e a prevenção devem ser planejados para permitir a máxima segurança sanitária possível em um evento sem impedir sua realização plena.

\subsection{RISCO POTENCIAL DE TRANSMISSÃO DO SARAMPO EM EVENTOS DE MASSA: MEDIDAS PREVENTIVAS PARA OS JOGOS OLÍMPICOS - RIO 2016}

O número de casos suspeitos e confirmados de sarampo em 2015 relatados pela Organização Mundial da Saúde - OMS ${ }^{36}$, indica um quadro no qual a Região Africana apresenta o maior índice de casos confirmados, enquanto a Região das Américas possui as menores taxas, tendo-se a seguinte distribuição: Região Africana (54.374 suspeitas/35.557 confirmadas), Região das Américas (13.083 suspeitas/366 confirmadas), Região do Mediterrâneo Oriental (26.178 suspeitas/11.610 confirmadas), Região Europeia (6.642 suspeitas/6.023 confirmadas), Região do Sudeste Asiático (79.713 suspeitas/67.233 confirmadas) e Pacífico Ocidental Região 
(120.319 suspeitas/61.493 confirmadas). Representando um total de 300.309 casos suspeitos e 182.282 casos confirmados no mundo até outubro de 2015.

A OMS relata que, de junho de 2014 a junho de 2015 no continente europeu, houve mais de 4000 casos reportados em 30 países, dos quais a Alemanha apresentou o maior número de casos (58,2\%), seguido por Áustria, Bielorrússia, Lituânia, Dinamarca, Noruega, Reino Unido, França, Suécia e Bélgica ${ }^{37}$.

Nos Estados Unidos ${ }^{38}$, destino turístico mais procurado (2014 - n=2,26 milhões) por viajantes brasileiros ${ }^{39}$, houve 23 surtos ( $\mathrm{n}=644$ casos) apenas em 2014. De janeiro a setembro de 2015 houve 189 casos confirmados em 24 estados, desses, 117 casos (62\%) estavam no estado da Califórnia. A maioria desses casos foi associada a viajantes estrangeiros que vieram para os EUA da Europa ${ }^{40}$, demonstrando como viajantes infectados podem contribuir para desencadear um surto em áreas suscetíveis. Isso também é observado em outras situações, como na China durante o ano novo chinês, muitos casos de sarampo são relatados com maior frequência em regiões distintas, o aumento durante esse período indica que os eventos de massa em alguns locais podem auxiliar na transmissão viral ${ }^{41}$.

O quadro mundial atual de sarampo ${ }^{42}$ indica surtos na República Democrática do Congo, Guiné, Sudão, Austrália, Mali, Argélia, Chile, Peru, Camarões, Malásia e Taiwan. Além disso, de acordo com os dados apresentados recentemente (fevereiro de 2016) pela OMS, a distribuição de casos de sarampo por mês aumentou significativamente nos últimos 2 anos nas regiões do Sudeste Asiático e países da região do Pacífico Ocidental ${ }^{43}$. 
De acordo com a Secretaria de Saúde de São Paulo ${ }^{44}$, a cobertura de vacinação foi estimada em mais de $90 \%$ em crianças de 1 ano no Estado de São Paulo durante o período de 1993-1996, culminando em uma diminuição significativa da incidência de Sarampo. Esta ampla cobertura vacinal deveu-se à vacinação de rotina aplicada por unidades de atenção primária, onde a população tem acesso à vacinação e as informações sobre as campanhas nacionais de vacinação, planejadas a cada 5 anos no Brasil, que são aplicadas para grupos-alvo específicos (crianças de 1 a 12 anos), reduzindo drasticamente o número de casos autóctones confirmados desde 2000, ano em que apenas 29 casos foram reportados em todo o país ${ }^{45}$. A transmissão autóctone do sarampo foi considerada interrompida no Brasil, bem como em todos os outros países do continente americano desde 2000.

Infelizmente, nos últimos 15 anos, o Brasil ainda apresentou alguns surtos principalmente na Região Nordeste. O maior foi em 2014, quando o Ministério da Saúde relatou 730 casos no país, dos quais 696 ocorreram no Estado do Ceará. Além disso, ocorreu um evento importante na época, a Copa do Mundo de Futebol de 2014, com 169.325 viajantes internacionais e 194.117 viajantes domésticos ${ }^{46}$, e o Estado do Ceará recebeu 6/64 partidas do evento. Embora a investigação não tenha encontrado o caso zero no surto de Pernambuco, é importante ressaltar que começou uma semana após as festividades do "Carnaval" que atraem anualmente milhares de turistas nacionais e estrangeiros para o estado ${ }^{47}$. Nesta região, a população adulta afetada, que foi vacinada apenas durante a infância, pode ter se exposto ao risco devido à baixa cobertura vacinal e à diminuição da proteção induzida pela vacina, provavelmente repetindo um quadro conhecido ${ }^{48}$. 
Infelizmente, devido a muitos fatos, como falha de cobertura de vacinação, baixas condições socioeconômicas de algumas regiões e aumento do número de viajantes, o vírus teve condições de se espalhar em algumas áreas que anteriormente eram consideradas seguras para qualquer viajante.

Casos de transmissão do sarampo em voo doméstico, também foram relatados na literatura, demonstrando que o vírus pode ser facilmente transmitido em locais confinados em uma população suscetível ${ }^{49}$.

O sarampo no Brasil foi considerado controlado até 2012, apresentando aumento em 2013 ( $n=200$ casos). O primeiro alerta regional foi em Pernambuco (2013 - 27 e 2014 - 197 casos confirmados) e um surto considerável no estado do Ceará apresentando $n=696$ (95,3\% do total de casos no país). Em 2015, podemos observar um cenário distinto, com uma aparente diminuição com $\mathrm{n}=164$, até outubro $^{50}$, terminando em setembro de 2015. A disseminação rápida pela região Nordeste se deveu à aparente baixa cobertura de vacinação ${ }^{51}$ em crianças abaixo de 1 ano, população esta não incluída nos grupos-alvo, com um número considerável de indivíduos infectados (28,6\%), seguido de adultos (20/29 anos - 26,8\%) e adolescentes (15/19 anos - 10,4\%). Destes, 89\% não foram vacinados contra o Sarampo.

A região Sudeste teve menor número de casos com $0,4 \%$ ( $n=3$ casos confirmados) no Rio de Janeiro e 0,95\% ( $\mathrm{n}=7$ casos confirmados) em São Paulo. Em ambos os estados, os viajantes brasileiros visitaram regiões endêmicas importando o vírus. Enfatizamos que a questão das falhas limitadas na cobertura podem ser 
observadas nos surtos de caxumba em 2015 no Rio de Janeiro ( $\mathrm{n}=568$ casos confirmados $)^{52}$ e São Paulo ( $\mathrm{n}=118$ casos confirmados $)^{53}$

A vacinação de rotina com a vacina tríplice (Sarampo, Caxumba e Rubéola) estabeleceu o grupo-alvo de mulheres em idade reprodutiva e crianças em unidades de atenção primária $^{51}$, e as estratégias de vacinação ocorridas desde 1992 concentraram-se apenas na faixa infantil (1-12 anos), seguida de vacinação de rotina e seguimento campanhas de reforço (faixa etária de 1-4 anos) a cada $5 \operatorname{anos}^{54}$. Uma campanha nacional com a Vacina Tríplice foi realizada em 2008 para alcançar o objetivo da eliminação da Rubéola e da Síndrome da Rubéola Congênita (SRC) principalmente na idade adulta ${ }^{55}$. O Brasil não teve relatos de rubéola nos últimos $5 \operatorname{anos}^{56}$, mas o ressurgimento do sarampo e caxumba com número significativo de casos entre 20-29 anos de idade, demonstra a necessidade da vacinação de reforço.

Os adultos podem receber a vacina gratuitamente, e a informação técnica está disponível, inclusive para os viajantes, mas uma campanha efetiva para esclarecer e elucidar a população é necessária para prevenir situações como o surto do Ceará em vista do aumento de viajantes estrangeiros recebidos ${ }^{57}$

Os países desenvolvidos enfrentam uma questão relacionada aos movimentos contra vacinação, onde os pais, devido a rumores de eventos adversos decorrentes da imunização, não vacinam seus filhos ${ }^{58}$, representando um novo problema para as estratégias de controle de doenças altamente contagiosas em países emergentes que possuem a doença em um quadro relativamente controlado, como o Brasil. 
A disseminação rápida do sarampo na Região Nordeste é provavelmente o resultado da desqualificação da questão pelos governos locais, principalmente após a questão ser gerenciada diretamente pelos municípios, o que levou a um atraso na resposta da saúde pública e, eventualmente, à infecção de adultos que não foram vacinados e, em seguida, a disseminação do vírus para os seus filhos ${ }^{51}$. O ressurgimento do sarampo em 2014, como um surto limitado no Brasil, também está correlacionado com o aumento do fluxo de entrada dos turistas para o país, bem como a viagem de brasileiros para o exterior para áreas endêmicas ${ }^{47}$.

Considerando todos os dados anteriores, os Jogos Olímpicos apresentariam um cenário favorável para a transmissão do sarampo para a população suscetível devido ao encontro massivo de pessoas em locais geralmente fechados ${ }^{59}$, como restaurantes, aeroportos, transportes públicos, shoppings e também áreas de confluência. O Ministério do Turismo do Brasil estima que 500 mil viajantes estrangeiros vieram para o evento ${ }^{1}$ (29), incluindo pessoas de áreas com surtos recentes como China, Alemanha e outros países.

A fim de evitar um surto de sarampo no país durante os Jogos Olímpicos de 2016, foi realizada a vacinação de todos os profissionais do turismo e grupos de funcionários que trabalharam direta e indiretamente com o evento, incluindo equipes de aeroviários, funcionários de hotel e restaurantes, e profissionais de saúde. A orientação da comunidade médica para o diagnóstico rápido de doenças também foi importante para evitar a disseminação rápida de doenças, evitando-se o que ocorreu na região Nordeste em 2014. 
A conscientização dos Ministérios de Saúde em relação a medidas preventivas durante eventos de massa internacionais em todo o mundo é uma preocupação especialmente pelas condições suscetíveis que apresentam para doenças de transmissão fácil, como o sarampo, que podem ser importados facilmente bem como o tráfego doméstico que permite sua ampla disseminação no território dos países que os sediam.

Além disso, os viajantes brasileiros têm procurando mais informações sobre os riscos de transmissões de doenças durante uma viagem. Existem pelo menos 132 centros de Medicina de viagens disponíveis para a população. Na maioria deles, a vacinação é gratuita, potencialmente reduzindo a chance de entrada de determinadas doenças preveníveis. Os viajantes estrangeiros também devem se vacinar para evitar a importação de sarampo para países emergentes como o Brasil.

Finalmente, uma doença com controle simples, como o Sarampo, pode se tornar uma epidemia em larga escala em determinados países se não houver um planejamento consciente das políticas de saúde pública para evitar tais situações relacionadas aos fluxos de viagens internacionais.

\subsection{MEDIDAS PREVENTIVAS PARA INSTALAÇÕES DE HOSPEDAGEM "PET FRIENDLY": ASSOCIAÇÃO ENTRE ROTA DE EXPANSÃO DA LEISHMANIOSE EM SÃO PAULO E MEDIDAS PREVENTIVAS PARA O DESLOCAMENTO DE ANIMAIS DOMÉSTICOS}

A medicina de viagem possui novos desafios de saúde pública devido ao aumento das viagens internacionais ( 2015 - $n=1,1$ bilhões) e a inclusão de animais de estimação neste quadro, podendo intensificar a transmissão de muitas zoonoses. As instalações para animais de estimação estão aumentando significativamente em muitos países, conforme dados da American Pet Products Association - APPA, que estimou 
uma receita de US \$ 62,75 bilhões, um aumento de $4 \%$ em relação a $2015^{60}$. Muitos animais de estimação são importados de outros países, como exemplo, no Reino Unido, onde 164.836 cães foram introduzidos nos últimos anos, conforme as normas internacionais para transporte de animais, com a importação de 65.080 cães de 128 países diferentes apenas em $2015^{61}$. Por esse motivo, alguns países implementaram medidas transfronteiriças com base em certificados de vacinação, particularmente para raiva e outras doenças zoonóticas ${ }^{62}$.

No entanto, o deslocamento doméstico de animais de companhia entre cidades feita por via terrestre em curta distância representa um alto risco devido à inexistência de vigilância específica para esta atividade, proporcionando um ambiente favorável para o deslocamento de doenças zoonóticas emergentes e reemergentes ${ }^{63}$, porque os animais de estimação que viajam estão potencialmente expostos a novos patógenos em destinos turísticos, podendo transportar essas doenças para seus locais de origem. Este sistema pode ser considerado dentro do modelo interpretativo de One Health ${ }^{64}$, um conceito que reconhece que a saúde dos seres humanos está ligada à saúde dos animais e ao meio ambiente no mundo como um todo. Segundo dados do IBGE $^{65}$, no Brasil existem 52,2 milhões de cães e 22,1 milhões de gatos em domicílios, sendo um número considerável de animais de estimação que representam um mercado de consumo que inclui viagens turísticas e outros serviços, tendo-se alguns destes regras específicas.

Infelizmente, $25 \%$ desses animais no Brasil não foram vacinados contra a raiva no último ano, mesmo com a existência de campanha anual e distribuição gratuita de vacinas nas principais capitais ${ }^{66}$. 
Considerando o aumento potencial de viagens locais de animais de estimação, esse comportamento negligente dos proprietários de animais de companhia com doenças preveníveis poderia ser um risco para outras zoonoses, como Leishmaniose Visceral (LV) no Brasil. Um estudo recente realizado no país revelou que apenas $24 \%$ dos donos de animais levam seus animais de estimação para consultas regulares e apenas $75 \%$ procuraram um veterinário quando o animal de estimação apresentou um problema de saúde grave ${ }^{67}$, sugerindo que medidas preventivas para doenças infecciosas ou mesmo vacinação poderiam ser um importante aspecto, que é negligenciado. Este problema exige um modelo de vigilância para viagens curtas de animais de estimação, mas esse objetivo pode não ser tão simples de ser alcançado.

No Brasil, as empresas de hospitalidade procuram atrair esse novo grupo composto por animais de estimação e seus donos, criando estabelecimentos específicos identificados como "Pet Friendly". O enorme crescimento das viagens exige o desenvolvimento de medidas preventivas para assegurar um deslocamento seguro com o estabelecimento de um sistema de vigilância de doenças infecciosas que possam alertar esse grupo sobre riscos potenciais.

De certa forma, algumas doenças com este determinante animal-humano são mapeadas no Brasil, mas sua conversão em informações de proteção de saúde pública não acontecem com a velocidade necessária, como o caso da LV no Estado de São Paulo, uma doença parasitária que no Brasil é causada pela espécie Leishmania infantum chagasi. A doença está se expandindo em nosso país com uma incidência de 3500 casos/ano em humanos e, apesar da maior incidência de casos se concentrar nas 
regiões Nordeste e Norte do Brasil, o aumento de casos humanos em 2015 (16\%) na região Sudeste, área considerada de baixa endemia, representa uma nova considerável questão de saúde pública ${ }^{68}$.

O ciclo de transmissão começa quando o inseto vetor (Lutzomia longipalpis) ingesta o parasita em invertebrados hospedeiros (reservatório de mamíferos) e depois infecta humanos no momento em que se alimenta de seu sangue ${ }^{69}$. Entre os principais reservatórios da $L V$, o cão doméstico se destaca na disseminação da doença devido ao seu importante papel no contexto das relações humanas.

O avanço da LV no estado de São Paulo ocorre progressivamente (Cidades com advertências para LV-n=123 - 76 Humana e Canina/47 somente Canina), em condições de limitação ambiental e em população canina susceptível restrita a uma área geográfica com dispersão potencial lenta (migração de cães infectados entre cidades / existência de vetor). De 1999 a 2014, foram relatados 5.798 casos suspeitos de LV em seres humanos, sendo 2.467 confirmados como autóctones em 85 municípios, com 214 óbitos, resultando em uma taxa de mortalidade de 8,7\% (214/2467) e a concentração de casos na região noroeste do estado ${ }^{70}$.

Concomitantemente, o número de instalações voltadas para animais de estimação no Brasil aumentou para $n=174$, sendo $32,75 \%$ desses equipamentos situados no Estado de São Paulo (n=57) distribuídos em 26 cidades com potencial de transmissão silenciosa para LV. Os hotéis estão localizados em áreas sem casos caninos confirmados, mas três deles apresentam casos confirmados em cidades limítrofes: São Paulo - Capital do Estado, Araçoiaba da Serra e Ribeirão Preto. São 
Paulo e Ribeirão Preto possuem casos confirmados em seres humanos $(n=17$ / n = 3), apresentando risco relativo $(\mathrm{n}=10 / \mathrm{n}=1)$ devido aos casos serem autóctones e, aparentemente, não haver vetor direto para continuar o ciclo de transmissão de cães para humanos (Tabela 2).

Tabela 2 - Casos Humanos e Caninos de Leishmaniose Visceral no Estado de São Paulo - 2016

\begin{tabular}{|c|c|c|c|c|c|c|}
\hline \multirow{2}{*}{ City } & \multirow{2}{*}{$\begin{array}{l}\text { Pet Friendly } \\
\text { Facilities }\end{array}$} & \multicolumn{2}{|c|}{$\begin{array}{c}\text { Canine Visceral } \\
\text { leishmaniasis - } 2015\end{array}$} & \multicolumn{2}{|c|}{$\begin{array}{c}\text { Human Visceral } \\
\text { leishmaniasis - } 2015\end{array}$} & \multirow{2}{*}{ Classification } \\
\hline & & Conf Cases & Death & Conf Cases & Death & \\
\hline Araçoiaba da Serra & 2 & 0 & 0 & 0 & 0 & silent, non-receptive and vulnerable \\
\hline Aramina & 1 & 0 & 0 & 0 & 0 & silent, non-receptive and not vulnerable \\
\hline Araras & 1 & 0 & 0 & 0 & 0 & silent, non-receptive and vulnerable \\
\hline Atibaia & 1 & 0 & 0 & 0 & 0 & silent, non-receptive and vulnerable \\
\hline Brotas & 6 & 0 & 0 & 0 & 0 & silent, non-receptive and vulnerable \\
\hline Campos do Jordão & 2 & 0 & 0 & 0 & 0 & silent, non-receptive and vulnerable \\
\hline Caraguatatuba & 2 & 0 & 0 & 0 & 0 & silent, non-receptive and vulnerable \\
\hline Guarujá & 2 & 0 & 0 & 0 & 0 & silent, non-receptive and vulnerable \\
\hline Illhabela & 3 & 0 & 0 & 0 & 0 & silent, non-receptive and vulnerable \\
\hline Itapevi & 1 & 0 & 0 & 0 & 0 & silent, non-receptive and vulnerable \\
\hline Mairiporã & 1 & 0 & 0 & 0 & 0 & silent, non-receptive and vulnerable \\
\hline Monte Alegre do Sul & 2 & 0 & 0 & 0 & 0 & silent, non-receptive and vulnerable \\
\hline Natividade da Serra & 1 & 0 & 0 & 0 & 0 & silent, non-receptive and not vulnerable \\
\hline Peruíbe & 1 & 0 & 0 & 0 & 0 & silent, non-receptive and not vulnerable \\
\hline Piedade & 1 & 0 & 0 & 0 & 0 & silent, non-receptive and vulnerable \\
\hline Ribeirão Preto & 1 & 0 & 0 & 3 & 0 & silent, non-receptive and vulnerable \\
\hline Santo Antônio do Pinhal & 2 & 0 & 0 & 0 & 0 & silent, non-receptive and not vulnerable \\
\hline São Bento do Sapucaí & 1 & 0 & 0 & 0 & 0 & silent, non-receptive and not vulnerable \\
\hline São José do Barreiro & 1 & 0 & 0 & 0 & 0 & silent, non-receptive and vulnerable \\
\hline São Luís do Paraitinga & 1 & 0 & 0 & 0 & 0 & silent, non-receptive and not vulnerable \\
\hline São Paulo & 9 & 0 & 0 & 17 & 0 & silent, non-receptive and vulnerable \\
\hline São Sebastião & 5 & 0 & 0 & 0 & 0 & silent, non-receptive and vulnerable \\
\hline Serra Negra & 3 & 0 & 0 & 0 & 0 & silent, non-receptive and vulnerable \\
\hline Socorro & 5 & 0 & 0 & 0 & 0 & silent, receptive and vulnerable \\
\hline Torrinha & 1 & 0 & 0 & 0 & 0 & silent, non-receptive and vulnerable \\
\hline Ubatuba & 1 & 0 & 0 & 0 & 0 & silent, non-receptive and vulnerable \\
\hline Total & 57 & 0 & 0 & 20 & 0 & \\
\hline
\end{tabular}

Cidades com casos caninos confirmados por LV em cidades próximas Fonte: BEPA, 2015

De acordo com um estudo recente ${ }^{71}$, seis novas cidades são infectadas pela LV anualmente no Estado de São Paulo, e esse deslocamento não supervisionado de cães pode aumentar essa progressão.

No entanto, os estabelecimentos "Pet Friendly" podem receber e hospedar cães infectados e assintomáticos de cidades vizinhas com casos positivos e de regiões endêmicas para LV (Figura 2), aumentando o potencial de transmissão se 
considerarmos outros meios de infecção, como mecanismos não-vetoriais, o que pode promover a infecção de cão para cão ${ }^{72,73}$.

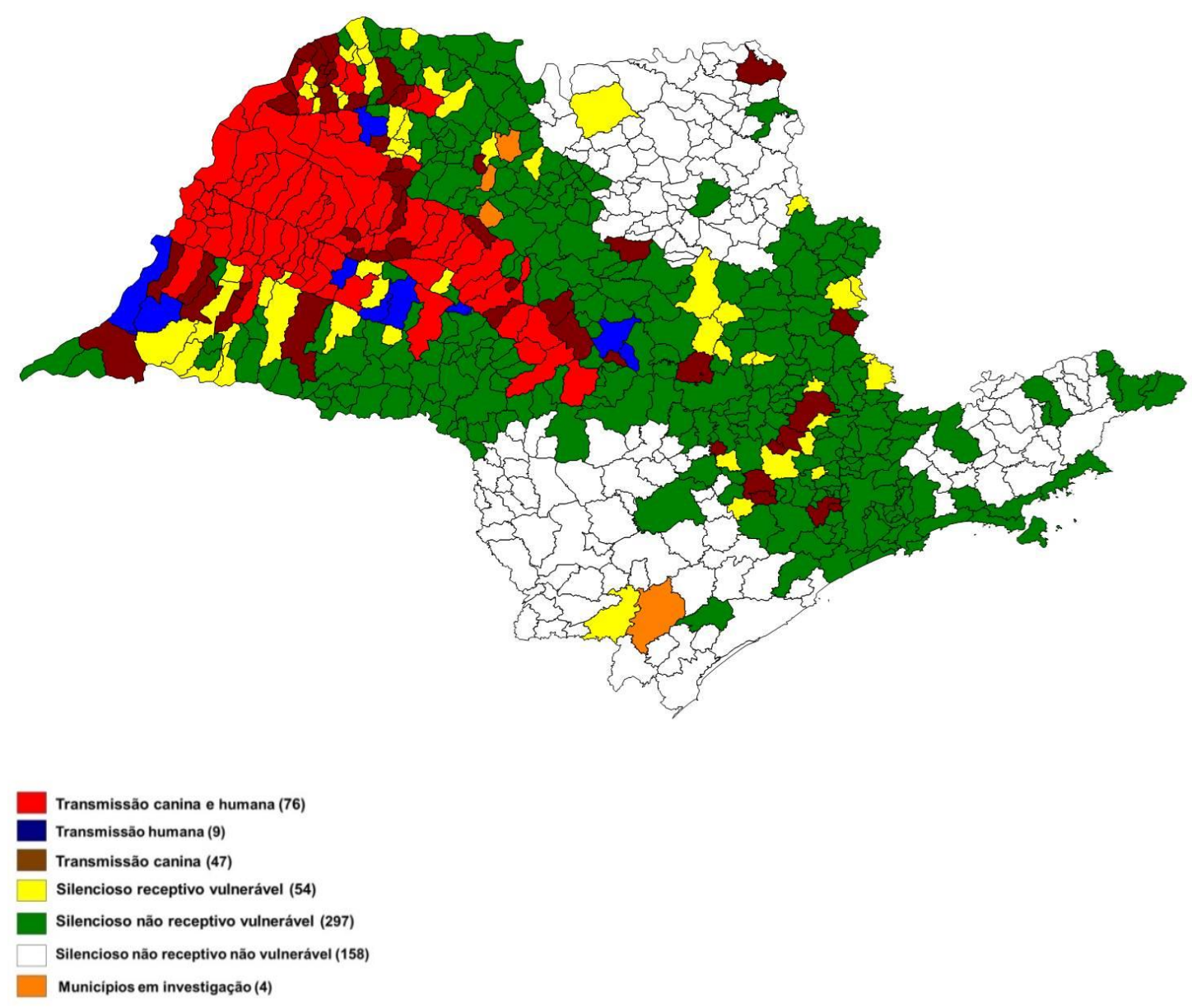

Figura 2 - Mapa de Classificação epidemiológica para Leishmaniose Visceral em dezembro de 2014, Estado de São Paulo ${ }^{70}$.

Neste cenário hipotético, o deslocamento doméstico dos animais de estimação sugere uma condição suscetível para aumentar a transmissão potencial de doenças emergentes e reemergentes, como LV e outras zoonoses parasitárias por protozoários, incluindo: Giardíase, Doença de Chagas, Toxoplasmose e Babesiose ${ }^{74}$, devido às barreiras geográficas não serem mais um fator limitante pois os reservatórios potenciais viajam para as regiões endêmicas no contexto atual. É uma nova condição e 
comportamento de viagens que afetará outros países, incluindo nações desenvolvidas como EUA, onde há 77,8 milhões de cães (> 49\%) e 85,8 milhões de gatos (> $288,23 \%$ ) como animais de estimação em $2015^{75}$. O continente europeu, por sua vez, também apresenta este fenômeno de animais de estimação e importação de doenças infecciosas, com o deslocamento de L. infantum, porém, a transmissão é limitada aos cães $^{76}$.

A situação da LV em São Paulo exige atenção devido aos óbitos suspeitos na área da comunidade de Barreira do João da Guarda - Cantagalo (uma importante Favela do Litoral de São Paulo), localizada perto da Praia da Enseada (2,2 km de distância), uma das mais importantes praias populares para viajantes no Guarujá ( $n=2$ instalações Pet Friendly), destacando a progressão da doença na área e o risco potencial para viajantes de curta distância. A primeira morte ocorreu em 28 de agosto de 2016, idade: 1 ano e 7 meses - sexo masculino, seguido 3 meses depois pela hospitalização do irmão mais velho, idade: 4 anos, que morreu em 21 de novembro. $\mathrm{O}$ cão da família teve diagnóstico positivo para LV de acordo com as autoridades locais. As amostras das primeiras crianças não foram coletadas devido ao seu óbito rápido sendo considerado como morte por causas naturais. A segunda morte está em análise para LV no Centro Infantil Boldrini, clínica de referência para diagnóstico de $\mathrm{LV}^{77}$.

A confirmação de LV no Guarujá suscita um novo movimento de avanço, não sendo lento e progressivo, mas randomizado, porque a cidade de Guarujá é um destino turístico litorâneo com uma distância considerável da cidade endêmica com transmissão canina confirmada (Taboão da Serra - distância de 116 km), demonstrando 
que o aumento do deslocamento de pessoas e animais pode gerar uma nova maneira potencial para transmissão de uma doença infecciosa.

Outras considerações importantes são a possível existência de um grande número de cães infectados nesta área turística; o salto na transmissão de caninos para seres humanos devido à existência do vetor principal para LV na região (L. longipalpis $)^{71}$ e o aumento potencial de casos humanos autóctones de LV nos próximos meses em outras cidades de São Paulo.

Para controlar essa preocupação potencial, os estabelecimentos Pet Friendly precisam de adaptações como a obrigatoriedade de um veterinário responsável no local e o estudo desta nova modalidade de viagem, atentando-se para novas questões como o aumento do risco real para transmissão de doenças entre estes animais de estimação, novas medidas preventivas a serem tomadas por estes empreendimentos como infraestrutura e demais requisitos para as instalações de hospedagem tanto de humanos quanto de animais, classificação de segurança para presença e potencial de transmissão para LV e outras doenças infecciosas na região a ser visitada, entre outras medidas.

O reporte de casos suspeitos deve ser realizado e disponibilizado o mais rapidamente possível por centros locais de controle de zoonoses para auxiliar os veterinários nesta ação protetora, e não como ocorre no contexto atual, onde estes dados se tornam acessíveis apenas 1 ano após a ocorrência.

No entanto, até que esta mobilização ocorra, precisamos começar com medidas preventivas razoáveis para os viajantes e seus animais de estimação, incluindo uma consulta veterinária pré-viagem para verificar a condição de saúde atual do animal, 
bem como o risco potencial e as doenças endêmicas da região a ser visitada, mesmo em um deslocamento curto. A vacinação de rotina para doenças como Leptospirose, Raiva, Lyme e outras doenças infecciosas aliadas a um certificado de vacinação pode ser uma política obrigatória para a aceitação dos viajantes e seus animais de estimação em um Estabelecimento Pet Friendly. Os veterinários podem recomendar outras medidas, como o uso de repelentes de insetos para animais de estimação e, em casos extremos, que se evite estas áreas de risco, sendo também responsáveis por melhorar este sistema de vigilância, incluindo outros métodos de controle de doenças infecciosas, como teste de animais e outras técnicas que asseguram esta nova modalidade de viagens regionais de curta distância.

\subsection{MUDANÇAS CLIMÁTICAS, ENCHENTES E AUMENTO DE ATIVIDADES DE LAZER EM ÁREAS NATURAIS: $O$ RISCO POTENCIAL PARA O AUMENTO DE CASOS DE ESQUISTOSSOMOSE}

As recentes mudanças climáticas globais desenvolveram novos cenários om alteração das bacias hidrográficas em algumas regiões do Brasil devido às chuvas extremas em períodos curtos, resultando em inundações devastadoras de determinadas áreas, seguidas de secas prolongadas ${ }^{78}$, comprometendo os sistemas de abastecimento de água, saneamento e higiene das cidades $^{79}$, o que poderia permitir o surgimento de doenças oportunistas.

As catástrofes naturais geralmente são seguidas de surtos que implicam na adoção de estratégias de mobilização e assistência especializada para a eliminação da origem da doença, quando possível, ou reduzindo as vias de transmissão ${ }^{80}$. 
Esta circunstância altera todos os ecossistemas locais, especialmente as áreas naturais, onde tais doenças infecciosas podem estar em latência, mas em virtude de novas condições possivelmente ocorre a disseminação para outras regiões devido à inexistência de barreiras naturais usuais, como as estações do ano, com sua delimitação climática específica ${ }^{81}$.

Um problema convergente é o aumento do ecoturismo e do turismo de aventura em todo o mundo, especialmente no Brasil (Gráfico 10). O contato direto dos viajantes com as áreas naturais pode levar ao contato involuntário e consequente contaminação por estas doenças endêmicas ${ }^{82}$.

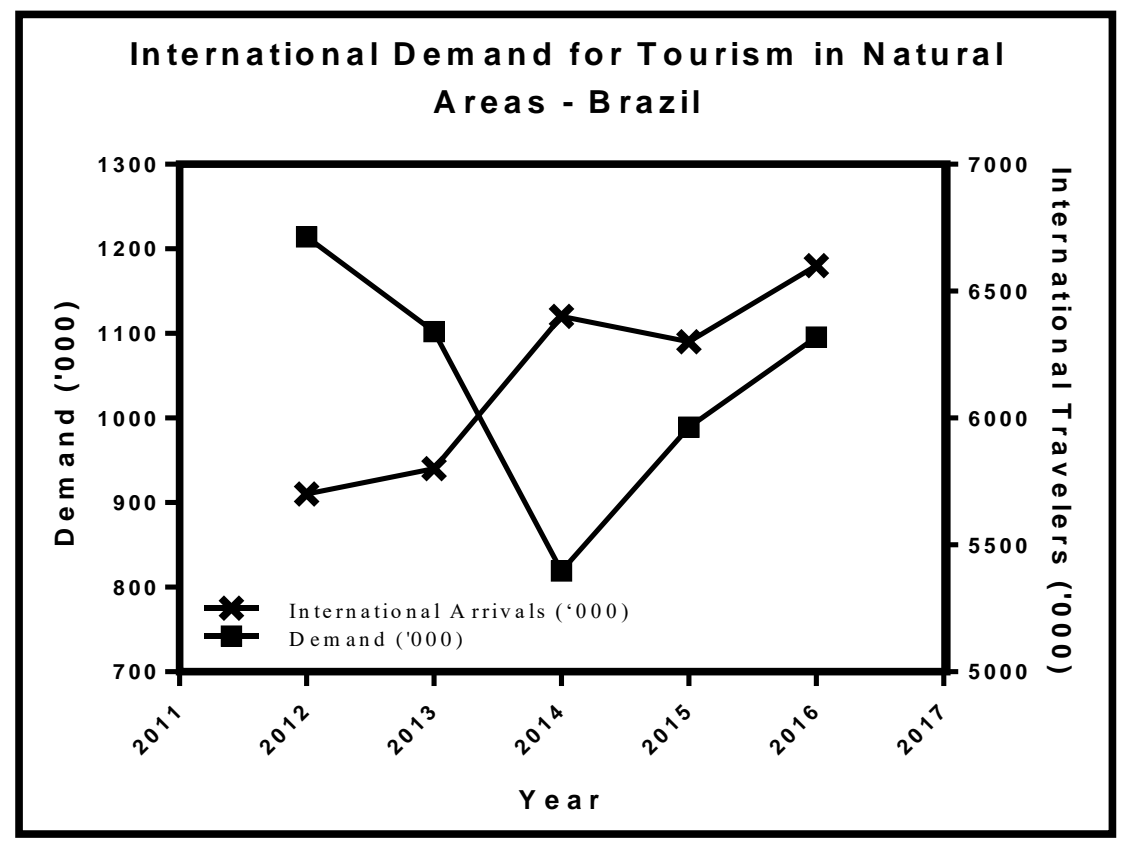

Gráfico 10 - Fluxo de Viajantes Internacionais X Demanda por Ecoturismo

Em sequência a esta linha de raciocínio, algumas doenças infecciosas oportunistas, apesar das séries históricas decrescentes (Tabela 3), apresentam alguns picos de incidência sazonal, como os recentes surtos de esquistossomose no Parque 
Nacional da Chapada Diamantina - Bahia, um dos destinos mais importantes para viagens de aventura e ecoturismo no Brasil. 
Tabela 3 - Casos de Esquistossomose no Brasil - 2007/2017

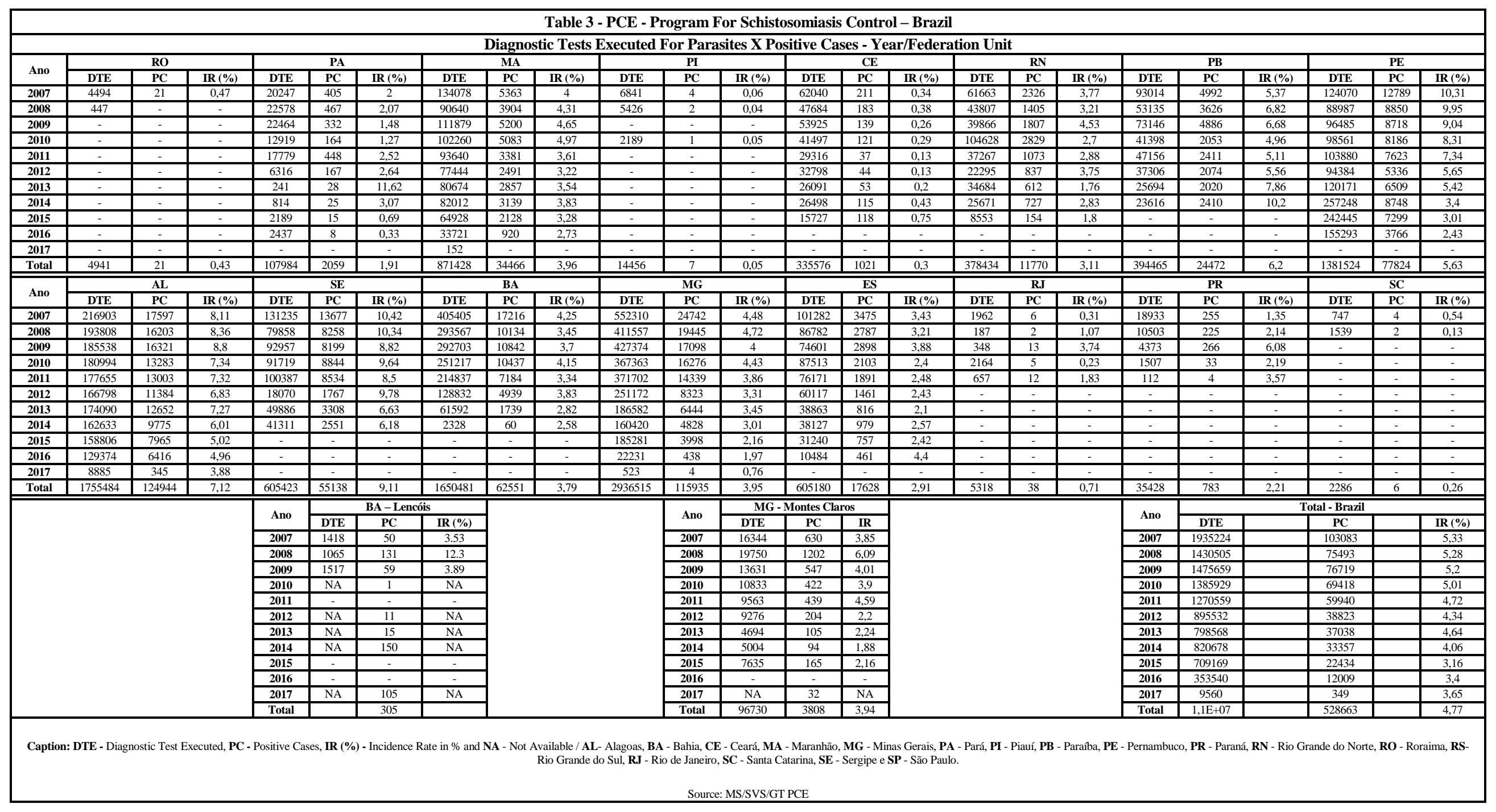


A esquistossomose é uma condição inflamatória crônica causada por trematóides parasitas do gênero Schistosoma que podem causar anormalidades hepáticas e anemia. O S. mansoni é a única espécie de Schistosoma no continente americano (6 no total - S. hematobium, S. japonicum, S. intercalatum, S. mekongi e S. malayensis).

No Brasil, a esquistossomose mansoni é epidêmica em algumas regiões do país e é considerada um grave problema de saúde pública devido ao número de óbitos por ano, sendo uma consequência das condições inadequadas de higiene e saúde em locais de extrema pobreza.

O ciclo de transmissão nas áreas urbanas envolve o ser humano que excreta ovos do parasita por meio de suas fezes e os caracóis aquáticos do gênero Biomphalaria, que atuam como hospedeiro intermediário, que liberam larvas de S. mansoni nas coleções de água contaminada usadas por humanos suscetíveis a adquirir pela pele ou mucosas em contato com este ambiente contaminado, gerando um processo contínuo.

De acordo com a Organização Mundial de Saúde ${ }^{83}$, 66,5 milhões de pessoas foram tratadas para esquistossomose, mas $\sim 218$ milhões de pessoas necessitariam de tratamento para esta doença infecciosa em 2015.

O primeiro surto de esquistossomose ocorreu em fevereiro de $2017^{84}$, após uma viagem de feriado (carnaval) em Lençóis, principal cidade do Parque Nacional da Chapada Diamantina. Um grupo de 32 ciclistas e parentes foram infectados depois de nadar em uma lagoa contaminada (Cachoeira do Mosquito), com o diagnóstico 
confirmado na cidade de origem do grupo para Schistosoma mansoni obtido após 45 dias da realização da viagem (Montes Claros - Minas Gerais).

A principal atividade de aventura não foi a verdadeira causa ou rota para a contaminação, mas uma atividade de lazer secundária desenvolvida neste ambiente natural. A investigação de outras atividades de lazer realizadas por viajantes de aventura em uma área natural pode ser um protocolo recomendado para diagnóstico. A cidade de Lençóis, que concentra a principais infraestruturas e serviços de suporte para viajantes de aventura, possui historicamente uma baixa incidência de casos positivos de esquistossomose junto à população local, mas as elevadas precipitações registradas em fevereiro ${ }^{85}$ contribuíram para a contaminação de cachoeiras e lagoas.

Outras chuvas extremas ocorreram em maio e junho, gerando um segundo surto de esquistossomose ${ }^{84}$ em junho de 2017(n = 105 casos positivos), após um grande período de enchentes, com a interdição de 2 novas áreas de recreação aquática (anteriormente o Poção, e agora o Poço Verde e Banho da Ponte, todos localizados na cidade de Lençóis).

Neste contexto, o aumento das atividades de lazer em áreas naturais, como o ecoturismo, pode ser uma prática de risco considerável devido ao contato direto de pessoas com áreas anteriormente consideradas seguras, mas agora contaminadas por agentes patogênicos que migram para sobreviver ou emergir após as intensas chuvas ou outros desastres naturais. Essas atividades podem acelerar a propagação de uma doença infecciosa em uma região e até a sua exportação para outros países. 
Devido às mudanças climáticas, outras regiões, incluindo algumas áreas de países desenvolvidos, podem apresentar rede causal favorável para que determinadas doenças sejam importadas e se adaptem facilmente, principalmente as tropicais e negligenciadas como esquistossomose.

O recente surto na França (Córsega) é um exemplo desse problema ${ }^{86}$. A rápida adaptação e transmissão da esquistossomose ocorreu devido às novas condições como a descoberta de um novo reservatório e o aumento das temperaturas nesta região com um inverno reduzido (a baixa temperatura em uma estação regular é uma barreira natural para a persistência do hospedeiro potencial), aliado à migração de refugiados ou à possível importação por cidadãos franceses que viajaram do norte da África para a Europa, resultando em um problema inesperado ${ }^{87}$.

As recomendações para viajantes às áreas naturais, especificamente para a prevenção da Esquistossomose mansoni, em regiões que foram afetadas por enchentes ou outras catástrofes naturais, são evitar atividades de recreação aquática, uso de botas impermeáveis e outras roupas de proteção e atenção especial para a higiene pessoal durante a viagem.

\subsection{EVIDÊNCIAS DA SAÚDE DOS VIAJANTES BRASILEIROS POR MEIO DO PERFIL EPIDEMIOLÓGICO DE UMA CLÍNICA PÚBLICA PARA VIAJANTES - SÃO PAULO - 2012/2016}

Os esforços efetivos para a medicina de viagem no Brasil se iniciaram na década de 1990 com o estabelecimento de clínicas públicas nas duas principais cidades para o fluxo de saída (Rio de Janeiro e São Paulo). Em duas décadas, ocorreu o crescimento de três clínicas na década de 90 para 237 unidades voltadas para a medicina do 
viajante, localizadas em todas as capitais brasileiras (27 estados), com alta concentração no Estado de São Paulo (n = 38 em 2014/ n = 87 em 2017).

Nos 20 anos de medicina de viagem no Brasil, os esforços iniciais foram limitados à prevenção de doenças domésticas, com o protocolo de verificação da cobertura vacinal dos viajantes para doenças preveníveis em consultas pré-viagem, com atenção para a Febre Amarela. O fluxo de saída dos viajantes brasileiros não era considerado um problema pois os turistas se deslocavam para países desenvolvidos considerados seguros.

As consultas em clínicas de viajantes apresentam aumento nos últimos 5 anos no Brasil devido à participação de países emergentes no mercado de viagens internacionais $(48,6 \%)$ aliada à visitação de novos destinos internacionais localizados em países em desenvolvimento.

Em 10 anos, o Brasil apresentou um desenvolvimento constante em sua estrutura de viagens, tendo 96,2 milhões de viajantes em viagens domésticas por via aérea, representando uma baixa taxa de incremento $(0,3 \%)$ se compararmos a 2014 (aumento de $6,3 \%$ em viagem).

O segundo semestre de 2015 apresentou queda no fluxo de viagens domésticas de $7,4 \%$ em relação ao ano de $2014^{88}$.

As consultas no Ambulatório dos Viajantes acompanharam essa oscilação ( $\mathrm{n}=$ 461- 2012 / n = 280 em 2016) devido à instabilidade econômica que reduziu o número de viagens no Brasil (nacional e internacional), conforme Gráfico 11. 


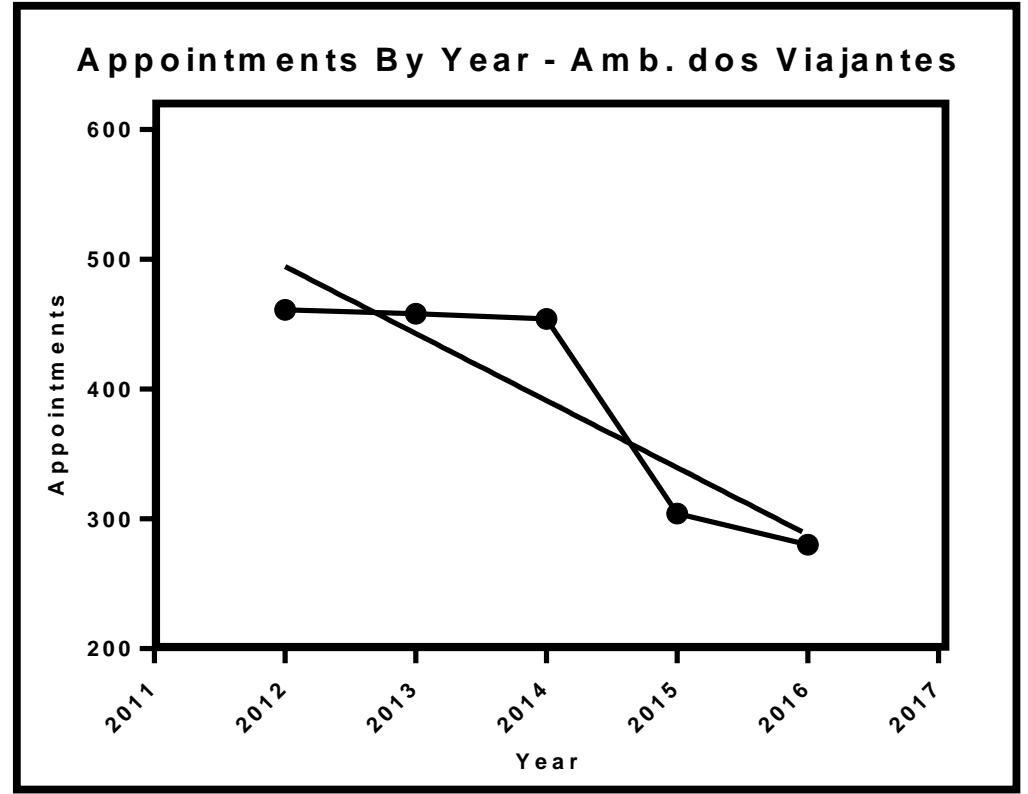

Gráfico 11 - Consultas por Ano - Ambulatório dos Viajantes/FMUSP-HC

De 2012 a 2014, o pico de consultas ocorreu em janeiro, com números semelhantes nos meses seguintes, exceto em maio (a clínica se torna um centro exclusivo para a vacinação contra influenza).

O fluxo de consultas nos anos de 2015 e 2016 apresentou picos no segundo semestre, com 2 meses de alta no número de consultas (julho e dezembro - em 2015 / outubro e novembro em 2016).

A proporção média de consultas pré-viagem foi $90,75 \%$, tendo-se um valor reduzido para atendimentos pós-viagem $(9,25 \%)$, conforme Tabela 4.

Tabela 4 - Consultas Pré e Pós Viagem por Ano - Ambulatório dos Viajantes FMUSP/HC - 2012/2016

\begin{tabular}{|c|c|c|c|c|c|}
\hline Year & Pre & $\%$ & Post & $\%$ & Total \\
\hline 2012 & 411 & 89,15 & 50 & 10,85 & 461 \\
\hline 2013 & 415 & 90,61 & 43 & 9,39 & 458 \\
\hline 2014 & 403 & 88,77 & 51 & 11,23 & 454 \\
\hline 2015 & 294 & 94,84 & 16 & 5,16 & 304 \\
\hline 2016 & 253 & 90,36 & 27 & 9,64 & 280 \\
\hline \multicolumn{2}{|c|}{ Mean Value } & 90,75 & & 9,25 & \\
\hline
\end{tabular}


Em 2016, do total de consultas $(n=280$ - Figura 12), a maioria foi de atendimentos pré-viagem $(\mathrm{n}=253$ - 90,36\%). Devido ao protocolo de atualização vacinal adotado, a maioria dos pacientes $(93,92 \%)$ recebeu algum tipo de vacina (dose regular ou de reforço), e 36,4\% foram imunizados para febre amarela.

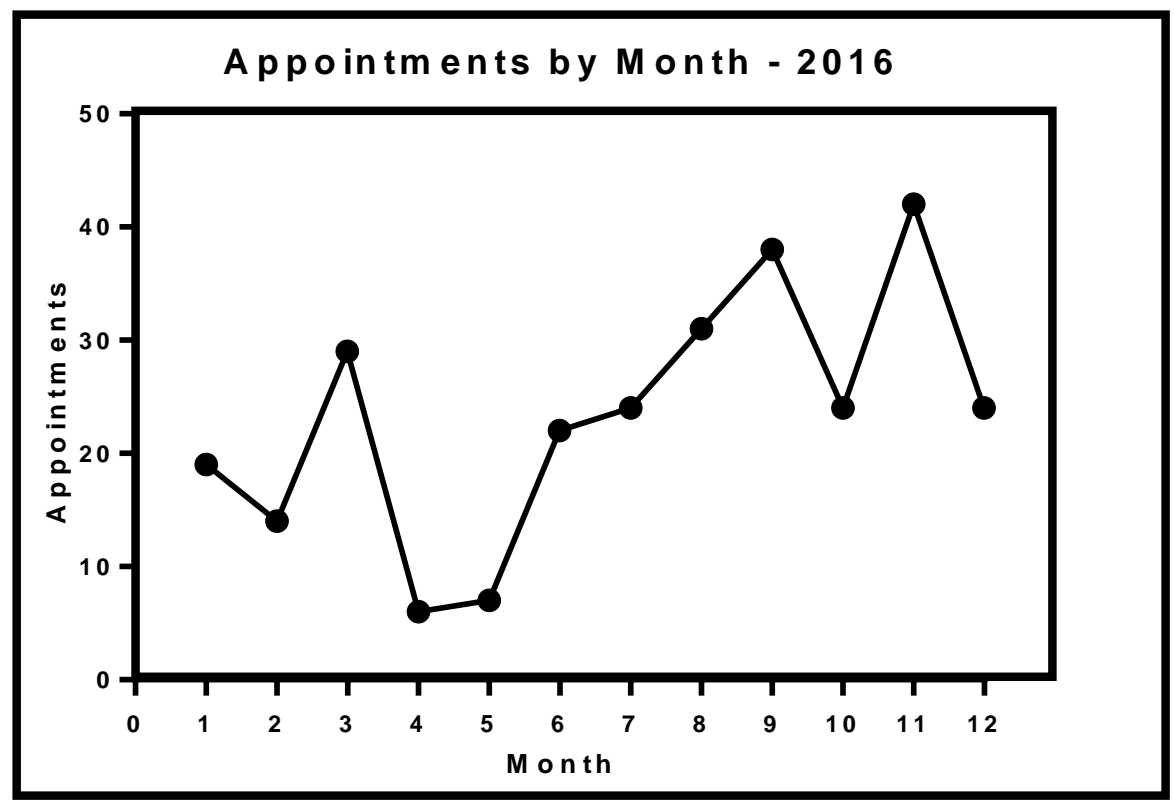

Gráfico 12 - Consultas por mês - Ambulatório dos Viajantes/FMUSP-HC - 2016

Os destinos de viagem tiveram a seguinte distribuição por continente (Tabela 5): Ásia - 33,1\%, África - 28,8\%, América Central e do Sul - 24,8\%), Europa - (Alemanha - 1,8\%, 2 ou mais países da UE - 5,8\%, Europa Oriental - 0,9\%), Nova Zelândia e Austrália (3,0\%); e América do Norte / Canadá (1,5\%). 
Tabela 5 - Consultas - Ambulatório dos Viajantes - FMUSP/HC - 2016

\begin{tabular}{|c|c|c|l|c|c|}
\hline \multicolumn{7}{|c|}{$\begin{array}{c}\text { Pable 5 - Ambulatório dos Viajantes - HC - Appointments - 2016 } \\
\text { Counselling }\end{array}$} & 253 & $\begin{array}{c}\text { Post Travel } \\
\text { Counselling }\end{array}$ & $\mathbf{2 7}$ \\
\hline \multicolumn{7}{|c|}{ Appointments by Age, Gender and Destination - 2016 } \\
\hline Age & (n) & $\%$ & \multicolumn{1}{|c|}{ Destination } & Total (n) & $\%$ \\
\hline $0-18$ & 12 & 4.29 & África & 94 & 28.83 \\
\hline $18-30$ & 87 & 31.07 & Asia & $\mathbf{1 0 8}$ & $\mathbf{3 3 . 1 3}$ \\
\hline $\mathbf{3 0 - 4 5}$ & $\mathbf{1 0 8}$ & $\mathbf{3 8 . 5 7}$ & Central And South America & 81 & 24.85 \\
\hline over 45 & 73 & 26.07 & Germany & 6 & 1.84 \\
\hline \multicolumn{7}{|c|}{} & & NZ and Australia & 10 & 3.07 \\
\hline Gender & $\mathbf{( n )}$ & $\%$ & North America and Canadá & 5 & 1.53 \\
\hline Female & $\mathbf{1 7 0}$ & $\mathbf{6 0 . 7 1}$ & Eastern European & 3 & 0.92 \\
\hline Male & 110 & 39.29 & Europe & 19 & 5.83 \\
\hline
\end{tabular}

A faixa etária atendida foi de 4 a 76 anos com predomínio do grupo Feminino 60,7\% na pré-viagem. O grupo de consulta pós-viagem é composto por 0-18 (3,7\%), 18-30 (29,6\%), 30-45 (33,3\%) e mais de 45 (33,3\%), com predomínio do sexo masculino $(62,9 \%)$.

A consulta pós-viagem $(n=27)$ teve a seguinte distribuição: Malária $(44,4 \%$ - 6 casos positivos de $P$. falciparum, 4 casos positivos de P. vivax e 2 não classificados), Febre (7,4\%), AGE- Gastroenterite Aguda (7,4\%), Hepatite A (3,7\%), Náusea (3,7\%), Mordida de Inseto (3,7\%), Dor Abdominal (3,7\%), Artralgia (3,7\%), Corrimento Vaginal $(3,7 \%)$ e em investigação $(18,5 \%)$.

A entrada de países emergentes como os BRICS (Brasil, Rússia, Índia, China e África do Sul) no cenário internacional de viagens gerou a necessidade de melhorar suas medidas preventivas para proteger seus cidadãos e reduzir o risco de importação de doenças infecciosas. No Brasil, a medicina de viagem é uma nova área de estudo 
que melhorou nos últimos $5 \operatorname{anos}^{89}$, e as clínicas de medicina de viagem são uma ferramenta importante para esse sistema de prevenção ${ }^{90}$.

O número de clínicas de medicina de viagem no Brasil foi de 132 em 2014 para 237 em 2016 (79,5\%), com maior participação do setor privado (de 33 para 112 unidades) e um impressionante desenvolvimento quantitativo em São Paulo (87 unidades $-128,5 \%-2016)^{91}$.

$\mathrm{O}$ alto investimento do setor privado em medicina do viajante indica que ser um segmento promissor e relevante $(221,43 \%$ - de 2014 a 2016), pois por meio do atendimento preventivo ocorre a diminuição de atendimentos pós-viagem e até de internação significando uma redução de custos com tratamento por parte das operadoras de assistência e seguro saúde.

Os dados preliminares das consultas no Ambulatório dos Viajantes da FMUSPHospital das Clínicas acompanharam esse fluxo que, após o segundo semestre de 2015, as consultas (Gráfico 13) reduziram significativamente (33,04\% em 2014-2015 e 7,89\% em 2015-2016). 


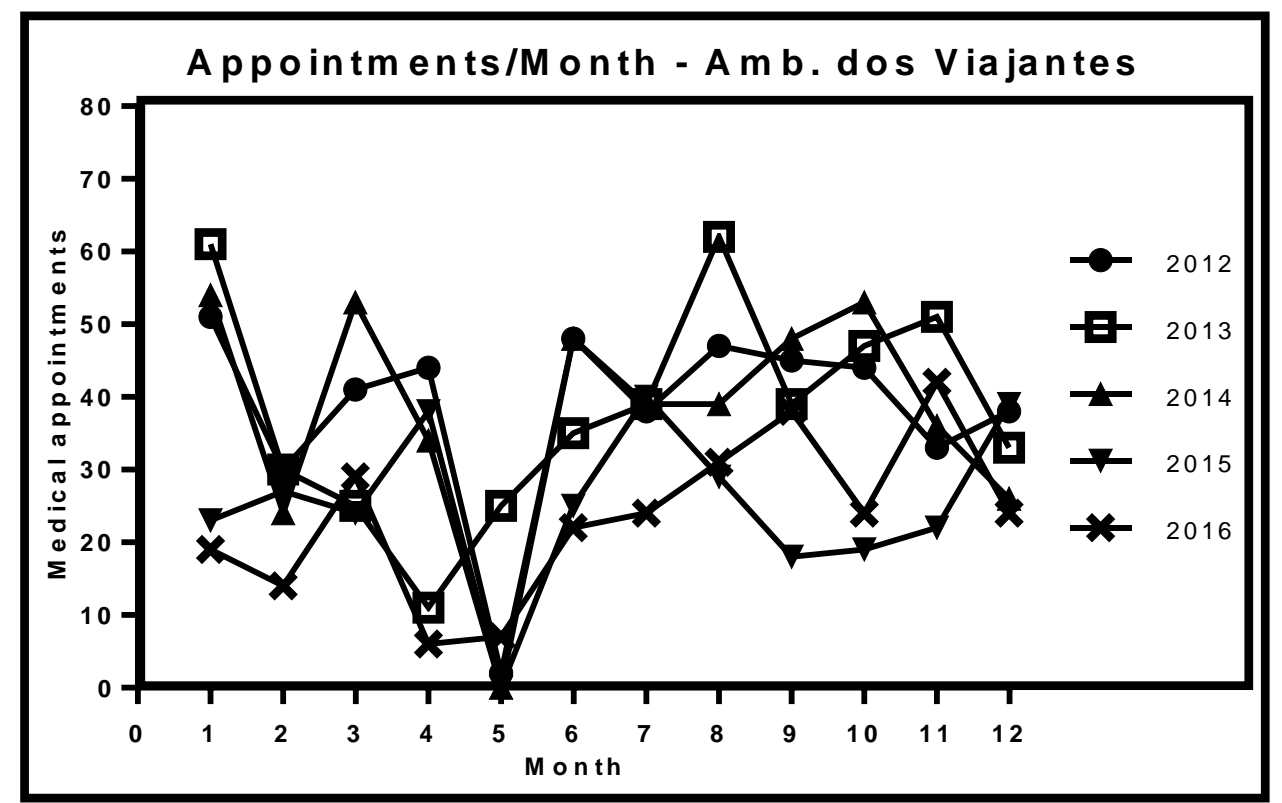

Gráfico 13 - Fluxo de Consultas -2012/2016

Outro fato importante é a queda na taxa de viajantes/100 habitantes que diminuiu de 48,1 para 47,9 em 2015, a primeira redução após 10 anos de desenvolvimento $(0,4 \%)$, correspondente ao período que inicia a atual recessão econômica no Brasil.

O principal período de atendimentos ocorre no início do ano com o pico em janeiro devido às férias escolares no Brasil que começam em dezembro ${ }^{92}$, tendo maior intensidade a partir da segunda semana do mês com o deslocamento das famílias para destinos internacionais. $\mathrm{O}$ segundo período de intensidade está relacionado às férias escolares de inverno.

Em 2016, a demanda e a oferta de tráfego aéreo doméstico reduziram em 2,8\% e 4,6\%, respectivamente em relação ao mesmo mês (dezembro) de 2015, apresentando o décimo sétimo mês consecutivo de retração da demanda interna. A oferta interna apresentou o décimo sexto mês consecutivo com queda ${ }^{93}$. O resultado acumulado até 
dezembro apresentou queda de 5,7\% na oferta, em relação ao mesmo período do ano anterior (2015).

Outro instrumento de aconselhamento pré-viagem foi o "Guia de bolso" para viajantes, publicado em 2012 pela Agência Nacional de Vigilância Sanitária ANVISA, órgão do governo responsável pelas inspeções sanitárias nos pontos de entrada no território brasileiro ${ }^{94}$. Trata-se de um manual rápido para viajantes com informações gerais como sintomas para as principais doenças infecciosas, regiões endêmicas e suas doenças, formas de transmissão de doenças infecciosas, bem como medidas de proteção e de bom comportamento durante a viagem.

Como estratégica complementar, o Ministério da Saúde estabeleceu um site com informações específicas para viajantes brasileiros ao exterior em $2014^{95}$, melhorando o sistema protetivo para viajantes.

Este website inclui links para as principais plataformas digitais de informação sobre saúde para o viajante internacional, tratados e acordos com alguns países para assistência médica gratuita para brasileiros, localização de clínicas de saúde de viagens públicas e imunização no Brasil, entre outras informações importantes para viagens seguras no Brasil e no exterior.

Apesar dessa aparente redução da atividade turística no Brasil, a atual rede de clínicas de medicina de viagem deve ser mantida devido à sua importância como fonte de planejamento estratégico em saúde, principalmente na prevenção de doenças. 
O perfil epidemiológico do Ambulatório dos Viajantes apresenta essa linha tática pela diferença entre a assistência pré (Valor Médio 90,75\%) e pós-viagem (Valor Médio 9,25\%).

A atualização de vacina dos viajantes contribui para a proteção de fronteiras, reduzindo o potencial para a importação de doenças infecciosas e até mesmo a disseminação doméstica devido aos viajantes assistidos serem imunizados para as principais doenças infecciosas preveníveis.

Os dados coletados como idade, destino e sexo são importantes para estimar os riscos ao qual podem estar expostos. Alguns estudos indicam que viajantes jovens tendem a ser mais suscetíveis à exposição aos riscos de saúde do que os idosos ${ }^{96}$.

Nossos dados apresentam um fluxo significativo de jovens $(31,07 \%)$ que buscam o continente asiático $(33,13 \%)$, principalmente para a região Sudeste (Tailândia), que apresentam um potencial para importação de doenças infecciosas ${ }^{97}$.

No entanto, os destinos internacionais mais visitados pelos brasileiros são os países da América do Sul com potencial semelhante para surtos de doenças negligenciadas, bem como a América do Norte e a Europa, que são considerados "locais seguros" por alguns viajantes brasileiros, porém, tem apresentado surtos de doenças controladas, como o sarampo, no Brasil ${ }^{98}$.

O grupo masculino apresenta mais comportamento de risco do que o feminino ${ }^{99}$, considerando a baixa demanda masculina em consultas pré-viagem $(39,29 \%)$ e pela sua predominância no atendimento pós-viagem $(62,96 \%)$. 
O Ambulatório dos Viajantes da FMUSP-HC compartilha seu espaço com o laboratório de referência para o diagnóstico da malária da Superintendência de Controle de Endemias da Secretaria de Estado da Saúde de São Paulo (SUCEN) dedicado à consulta pós-viagem, resultando em grande número de casos confirmados $(44,4 \%)$, podendo ser um resultado enviesado. A experiência prévia de viagens pode ser a causa da predominância de adultos (30-45-33,3\%) e grupos de pessoas idosas (acima de 45 - 33,3\%) na consulta pós-viagem.

A mesma estrutura inclui o Centro de Referência para Imunizações Especiais (CRIE - FMUSP-HC), com vacinação gratuita para as doenças infecciosas preveníveis comuns, especialmente para viajantes, e emissão do Certificado Internacional de Vacinação ou Profilaxia para Febre Amarela.

Devido a essa função social de imunização, a clínica apresenta uma relativa redução de consultas (Figura 15) no período da campanha nacional de vacinação contra Influenza que ocorre em maio ( $\mathrm{n}=7$ em 2016). Outras clínicas de medicina de viagem no Brasil têm essa função social de manutenção da cobertura vacinal no país para algumas doenças infecciosas como sarampo, caxumba, rubéola, pólio e outras ${ }^{100}$.

Aliado a essa estratégia nas consultas pré-viagem, de acordo com o itinerário do paciente, os médicos assistem os pacientes nas principais doenças infecciosas da área a ser visitada e, o mais importante, recomendam medidas preventivas específicas conforme o destino.

Esse protocolo pode ser considerado bem-sucedido devido às baixas taxas de consulta pós-viagem $(9,25 \%)$ nos últimos 5 anos, bem como possibilita inferir que os 
viajantes estão mais preocupados com sua saúde, sendo uma estratégia importante para evitar a importação de doenças infecciosas. As proporções de assistência pré e pós viagem estão no mesmo nível de eficiência que as clínicas de viagem nos países desenvolvidos $^{101-104}$.

Estes aspectos de atendimento mostram o cosmopolismo do turista. Esta visão global do turismo é contemporânea e deve ser a abordagem mais correta para o nosso futuro. Não podemos restringir a transferência voluntária de recursos que é o turismo com uma visão regional e preconceituosa. $\mathrm{O}$ turista global pode ter qualquer nacionalidade e deve ter os cuidados sanitários inerentes ao destino pretendido, mas isto independe da sua origem. Pelos nosso artigos de sarampo e zika vemos que os turistas funcionam apenas como transportadores de agentes, mas que os efeitos deste transporte não são relacionados diretamente ao turismo mas sim às condições regionais que permitem a propagação da doença nas populações da região, portanto das condições sanitárias regionais e não do turismo em si. Essa visão do turista como transportador principal tenta transferir a falha nos sistemas sanitários de prevenção para uma atividade, desviando o foco do fato primário que é a manutenção de uma rede causal de doença numa determinada região. 


\section{CONCLUSÕES}

O aumento das viagens internacionais auxilia na transmissão de doenças infecciosas, fazendo com que não existam limites espaciais ou temporais, mas sim a necessidade de esforços conjuntos para que sejam prevenidas e controladas, pois as endemias no contexto atual se estruturam em dispersão global, sendo uma preocupação de países pobres, mas também dos países desenvolvidos, pois basta a existência de uma rede causal para que uma doença negligenciada tenha êxito em qualquer localidade.

A participação crescente de países emergentes no cenário internacional de viagens torna necessário que estes países criem políticas públicas voltadas para a proteção de seus viajantes, bem como adotem medidas que evitem a entrada de viajantes estrangeiros doentes, principalmente para doenças controladas em seus territórios. As restrições e regulamentos de fronteira auxiliam no processo de prevenção para importação de doenças infecciosas, mas devem ser repensadas pelas nações como um conjunto de medidas que permitam a continuidade do fluxo de viagens e sua consequente redistribuição de renda, sendo parte de uma estratégia maior que possibilite o livre trânsito de pessoas realizado com segurança, e com o mínimo de exposição aos possíveis riscos.

Novos atores surgem no processo de controle epidemiológico de doenças, sendo o modelo de One Health cada vez mais presente, seja por animais de estimação em viagem, seja pelo contato direto de viajantes com áreas naturais e seu bioma, fonte esta de recreação em ascendência no contexto atual. Novos profissionais são 
requeridos para auxiliar na criação desta rede protetiva como veterinários, bem como há a necessidade de maior controle e supervisão de vetores e reservatórios nestes espaços exóticos de visitação.

A proteção individual realizada por cada viajante deve ser encorajada, principalmente em países emergentes com pouca tradição de viagens, sendo a consulta pré viagem, que no Brasil é gratuita nas principais capitais, uma das principais ferramentas para prevenção, pois nestas consultas são verificadas a cobertura vacinal do individuo, bem como são fornecidas informações que possibilitam ao viajante diminuir sua exposição à determinados riscos, bem como para certas doenças existentes no local a ser visitado. A ampla rede pública deve ser mantida para a continuidade desta rede protetiva cada vez mais necessária em vista do crescente fluxo de viajantes do Brasil para o exterior, bem como a sua merecida consolidação como destino de viagens internacional, tão necessária para equalização econômica financeira do país.

Assim, como síntese, o turista tem boas condições sanitárias independente da sua origem, quer seja dos BRICS ou de países desenvolvidos, podendo funcionar como um transportador eventual de doenças entre as nações. A implantação destas novas doenças nas regiões está relacionada à manutenção da rede causal de doença nestas localidades. Os sistemas de saúde do Mundo devem estar preparados para uma rápida transmissão de doenças, porém, a restrição contumaz da atividade turística não parece ser o modelo de contenção mais adequado. O método mas eficiente será a implantação de um sistema de segurança sanitária universal para diagnóstico, tratamento, prevenção 
e constante vigilância epidemiológica destas doenças, pois elas sempre serão nossas companheiras. 


\section{REFERÊNCIAS}

1. Brasil. Anuário Estatístico de Turismo 2017 - Volume 44 - Ano base 2016 [Internet]. Ministério do Turismo. 2017 [cited 2017 Oct 16].p. 371. Disponível em: file:///C:/Users/fast analia/Downloads/Anuario_Estatistico_Turismo_2017.pdf

2. MTUR. Anuário Estatístico de Turismo 2015. 2016; Disponível em: http://www.dadosefatos.turismo.gov.br/export/sites/default/dadosefatos/anuario/ downloads_anuario/Anuario_Estatistico_de_Turismo_2015__Ano_base_2014_-_Pdf.pdf

3. Silva V. A saúde do viajante na visão de três atores: gestores da saúde pública, gestores do turismo e o turista. Fundação Oswaldo Cruz; 2011.

4. United Nations World Tourism Organization. Tourism Highlights - 2016 [Internet]. Tourism Highlights - 2016. Geneva; 2016 [cited 2017 Feb 16]. Disponível em: http://www.e-unwto.org/doi/book/10.18111/9789284418145

5. European Parliament. Acervo de Schengen: tal como referido no n. o 2 do artigo

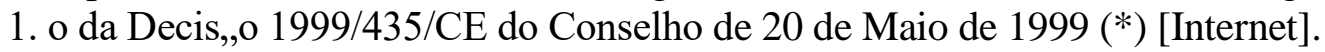
European Union; 1999. Disponível em: http://eur-lex.europa.eu/LexUriServ/ LexUriServ.do?uri=OJ:L:2000:239:0001:0473:PT:PDF

6. EUROSTAT. Tourism satellite accounts (TSAs) in Europe: 2013 edition. Luxembourg; 2014.

7. World Tourism Organization. UNWTO Annual Report 2015 [Internet]. Annual Report. Madrid: UNWTO; 2015 [cited 2017 Feb 16]. 978-92 p. Disponível em: http://www.dadosefatos.turismo.gov.br/images/pdf/estatisticas_indicadores/UN TWO_Annual_report_2015.pdf

8. Euromonitor International. World tourism data and statistics 2014. London; 2015 .

9. Union E-E. CEA Statistics $\mathrm{N}^{\circ} 46$ : European insurance in figures. [Internet]. 2013. Disponível em: http://www.insuranceeurope.eu/uploads/Modules/ Publications/eif-2013-final.pdf

10. Brazil. SES - Sistema de Estatísticas da SUSEP [Internet]. SUSEP Superintendência de Seguros Privados. 2013 [cited 2013 Oct 18]. Disponível em: http://www2.susep.gov.br/menuestatistica/SES/resp_premiosesinistros.aspx

11. European Parliament. Consolidated version of the treaty on European Union. [Internet]. European Union; 2007. Disponível em: http://eurlex.europa.eu/LexUriServ/LexUriServ.do?uri=OJ:C:2010:083:0013:0046:en:P 
DF

12. Vaz V. Gastando mais que europeu, turista brasileiro vira prioridade [Internet]. Terra networks. 2012 [cited 2017 Oct 16]. Disponível em: https://www.terra.com.br/economia/gastando-mais-que-europeu-turistabrasileiro-viraprioridade, 8588b781eab41410VgnCLD200000bbcceb0aRCRD.html

13. European Parliament. Directive 2011/24/eu of the European Parliament and of the Council. [Internet]. European Union; 2012. Disponível em: http://eurlex.europa.eu/LexUriServ/LexUriServ.do?uri=OJ:L:2011:088:0045:0065: EN:PDF

14. ISTAT. Chapter 4: Inequalities, equity and services for citizens. [Internet]. 2012. Disponível em: http://www.istat.it/en/files/2012/04/Pillole_Capitolo4_ING.pdf

15. Duarte-Davidson R, Orford R, Wyke S, Griffiths M, Amlot R, Chilcott R. Recent advances to address European Union Health Security from cross border chemical health threats. Env Int [Internet]. 2014;72:3-14. Disponível em: http://www.ncbi.nlm.nih.gov/pubmed/24679379

16. Brazil. Nota para a imprensa - 22.11.2013 [Internet]. Banco Central do Brasil. 2013 [cited 2013 Oct 18]. Disponível em: http://www.bcb.gov.br/?ECOIMPEXT

17. U.S. Department of Commerce. International visitation to the United States: A statistical summary of U.S. visitation (2010) [Internet]. 2011. Disponível em: http://travel.trade.gov/outreachpages/download_data_ table/2010_Visitation_Report.pdf

18. World Tourism Organization - UNWTO. Tourism Highlights - 2013 Edition. Madri; 2013.

19. DGCIS. Études et Statistiques [Internet]. 2013. Disponível em: http://www.dgcis.gouv.fr/etudes-et-statistiques/statistiques-du-tourisme/ accueil

20. Turísticos IET- I de E. Balance del Turismo - Año 2012: Resultados de la actividad turística en España [Internet]. 2013. Disponível em: www.iet.tourspain.es/es-ES/estadisticas/ analisisturistico/balantur/anuales/ Balance del turismo en España. Año 2012.pdf

21. Union E-E. CEA Statistics $\mathrm{N}^{\circ} 44$ : European insurance in figures [Internet]. 2013. Disponível em: http://www.insuranceeurope.eu/uploads/Modules/Publications/europeaninsurance-in-figures-2011.pdf

22. CARPES G. Seguro-viagem nega transferência, e brasileira com tumor é operada no Peru - Notícias - Cotidiano [Internet]. Folha de São Paulo. 2013 
[cited 2017 Oct 16]. Disponível em:

https://noticias.uol.com.br/cotidiano/ultimas-noticias/2013/09/17/seguroviagem-nega-transferencia-e-brasileira-com-tumor-e-operada-no-peru.htm

23. Thomé $\mathrm{C}$. Brasileira operada às pressas no exterior será transferida para o Brasil nesta quinta-feira - Brasil - Estadão [Internet]. O Estado de São Paulo. 2013 [cited 2017 Oct 16]. Disponível em:

http://brasil.estadao.com.br/noticias/geral,brasileira-operada-as-pressas-noexterior-sera-transferida-para-o-brasil-nesta-quinta-feira,1076178

24. Union E-E. CEA Statistics $\mathrm{N}^{\circ}$ 39: Insurance distribution channels in Europe [Internet]. 2013. Disponível em:

http://www.insuranceeurope.eu/uploads/Modules/Publications/cea-statistics-nr39---distribution.pdf

25. Assistance AG. 2012 Annual Report [Internet]. 2013. Disponível em: http://www.mondial-assistance.com.br/institucional/images/Annual Report 2012.pdf

26. FINACCORD. Travel Insurance and Assistance in Brazil [Internet]. 2014. Disponível em:

http://www.finaccord.com/uk/report_travel_insurance_assistance_brazil.htm

27. Hunter P. Tropical diseases and the poor: Neglected tropical diseases are a public health problem for developing and developed countries alike. EMBO Rep [Internet]. 2014;15(4):347-50. Disponível em:

http://www.ncbi.nlm.nih.gov/pubmed/24652851

28. Kwak K. An evaluation of the healthy immigrant effect with adolescents in Canada: Examinations of gender and length of residence. Soc Sci Med [Internet]. 2016;157:87-95. Disponível em: http://www.ncbi.nlm.nih.gov/pubmed/27064656

29. Urbano PR, Fujita DM, Romano CM. Reemergence of mumps in São Paulo, Brazil - the urgent need for booster shot campaign to prevent a serious infectious disease. Rev Soc Bras Med Trop [Internet]. 2017 Aug [cited 2017 Oct 6];50(4):535-8. Disponível em: http://www.ncbi.nlm.nih.gov/pubmed/28954076

30. De Cock KM, Simone PM, Davison V, Slutsker L. The new global health. Emerg Infect Dis. 2013;19(8):1192-7.

31. Steffen R, Behrens RH, Hill DR, Greenaway C, Leder K. Vaccine-preventable travel health risks: What is the evidence - What are the gaps? Vol. 22, Journal of Travel Medicine. 2015. p. 1-12.

32. Brazil. Monitoramento dos casos de dengue, febre de chikungunya e febre pelo vírus Zika até a Semana Epidemiológica 15, 2017 [Internet]. 2015 [cited 2017 May 19]. Disponível em: 
http://portalarquivos.saude.gov.br/images/pdf/2017/maio/05/Monitoramentodos-casos-de-dengue-febre-de-chikungunya-e-febre-pelo-virus-Zika-ate-aSemana-Epidemiologica.pdf

33. Dupont-Rouzeyrol M, O'Connor O, Calvez E, Daurès M, John M, Grangeon J$\mathrm{P}$, et al. Co-infection with Zika and Dengue Viruses in 2 Patients, New Caledonia, 2014. Emerg Infect Dis [Internet]. 2015 Feb [cited 2017 Oct 16];21(2):381-2. Disponível em: http://wwwnc.cdc.gov/eid/article/21/2/141553_article.htm

34. Zanluca C, Melo VC, Mosimann AL, Santos GI, Santos CN, Luz K. First report of autochthonous transmission of Zika virus in Brazil. Mem Inst Oswaldo Cruz [Internet]. 2015;110(4):569-72. Disponível em:

http://www.ncbi.nlm.nih.gov/pubmed/26061233

35. PAHO. Epidemiological Alert Zika virus infection 7 May 2015 [Internet]. 2015 [cited 2017 Oct 16]. Disponível em:

http://www.paho.org/hq/index.php?option=com_docman\&task=doc_view\&Ite $\mathrm{mid}=270 \&$ gid $=30075 \&$ lang $=\mathrm{en}$

36. WHO. Reported Measles Cases by WHO region 2014, 2015, as of 13 January 2016 [Internet]. 2016 [cited 2017 Oct 16]. Disponível em:

http://www.who.int/immunization/monitoring_surveillance/burden/vpd/surveill ance_type/active/measlesregionalsummary.pdf?ua $=1$

37. WHO. Total confirmed measles cases. 2015 [cited 2017 Oct 16]; Disponível em:

http://www.who.int/immunization/monitoring_surveillance/burden/vpd/surveill ance_type/active/measlesreportedcasesbycountry.pdf

38. CDC. Measles |Cases and Outbreaks |CDC [Internet]. 2015 [cited 2015 Oct 19]. Disponível em: https://www.cdc.gov/measles/cases-outbreaks.html

39. Brasil. Anuário Estatístico de Turismo - 2016 - Volume 43 - Ano base 2015 [Internet]. Ministério do Turismo. 2016 [cited 2015 Oct 15]. Disponível em: file:///C:/Users/fast analia/Downloads/Anuario_Estatistico_Turismo_2016_2 (1).pdf

40. Halsey NA, Salmon DA. Measles at Disneyland, a problem for all ages. Ann Intern Med [Internet]. 2015;162(9):655-6. Disponível em:

http://www.ncbi.nlm.nih.gov/pubmed/25751746

41. Hu X, Xiao S, Chen B, Sa Z. Gaps in the 2010 measles SIA coverage among migrant children in Beijing: evidence from a parental survey. Vaccine [Internet]. 2012;30(39):5721-5. Disponível em: http://www.ncbi.nlm.nih.gov/pubmed/22819988

42. ECDC. COMMUNICABLE DISEASE THREATS REPORT - CDTR - Week 5, 25-31 January 2015 [Internet]. 2015 [cited 2015 Oct 15]. Disponível em: 
https://ecdc.europa.eu/sites/portal/files/media/en/publications/Publications/com municable-disease-threats-report-31-jan-2015.pdf

43. WHO. Measles Case Distribution by Month and WHO Regions, 2008-2015. 2015; Disponível em:

http://www.who.int/immunization/monitoring_surveillance/burden/vpd/surveill ance_type/active/big_measlesmonthlyregionaldistribution_PDF.pdf

44. CVE CVE-C de VEPEC-. Plano Nacional de Erradicação do Sarampo São

Paulo: Coordenação dos Institutos de Pesquisa; 1999 [Internet]. São Paulo. 2015 [cited 2015 Dec 15]. Disponível em:

http://www.cve.saude.sp.gov.br/htm/resp/Planosar.htm

45. CVE CVE-C de VEPEC-. Progresso na Erradicação do Sarampo nas Américas São Paulo: Coordenação dos Institutos de Pesquisa; 1999 [Internet]. 2015 [cited 2015 Dec 16]. Disponível em:

http://www.cve.saude.sp.gov.br/htm/resp/semi_sp22.htm

46. Department $\mathrm{G}$ of C-T. Número de estrangeiros cresceu quase $650 \%$ se comparado com junho de 2013; impacto na economia superou R \$ 1,6 bilhão [Internet]. 2015 [cited 2015 Dec 16]. Disponível em:

http://www.setur.ce.gov.br/noticias/fluxo-turistico-para-a-copa-superaexpectativas/?searchterm $=$ copa turistas

47. Leite RD, Barreto JL, Sousa AQ. Measles Reemergence in Ceara, Northeast Brazil, 15 Years after Elimination. Emerg Infect Dis [Internet].

2015;21(9):1681-3. Disponível em:

http://www.ncbi.nlm.nih.gov/pubmed/26291505

48. Pannuti CS, Morello RJ, Moraes JC, Curti SP, Afonso AM, Camargo MC, et al. Identification of primary and secondary measles vaccine failures by measurement of immunoglobulin G avidity in measles cases during the 1997 Sao Paulo epidemic. Clin Diagn Lab Immunol [Internet]. 2004;11(1):119-22. Disponível em: http://www.ncbi.nlm.nih.gov/pubmed/14715557

49. de Barros FR, Danovaro-Holliday MC, Toscano C, Segatto TC, Vicari A, Luna E. Measles transmission during commercial air travel in Brazil. J Clin Virol [Internet]. 2006;36(3):235-6. Disponível em:

http://www.ncbi.nlm.nih.gov/pubmed/16720101

50. Ceará. Informe Epidemiológico - Encerramento do Surto de Sarampo - 24 de setembro de 2015 [Internet]. Fortaleza; 2015 [cited 2015 Dec 16]. Disponível em: file:///C:/Users/fast analia/Downloads/nota_encerramento_surto_do_sarampo_24_09_2015 (2).pdf

51. Rocha HA, Correia LL, Campos JS, Silva AC, Andrade FO, Silveira DI, et al. Factors associated with non-vaccination against measles in northeastern Brazil: Clues about causes of the 2015 outbreak. Vaccine [Internet]. 2015;33(38):4969- 
74. Disponível em: http://www.ncbi.nlm.nih.gov/pubmed/26215369

52. Fiocruz. Nota Técnica de Caxumba. 2015; Disponível em:

https://www.bio.fiocruz.br/index.php/noticias/1042-nota-tecnica-de-caxumba

53. CVE. CAXUMBA: Distribuição de surtos, casos e óbitos, segundo ano de início dos sintomas e faixa etária, Estado de São Paulo, 2001 a 2017* [Internet]. São Paulo; 2017 [cited 2017 Oct 16]. Disponível em:

http://www.saude.sp.gov.br/resources/cve-centro-de-vigilanciaepidemiologica/areas-de-vigilancia/doencas-de-transmissaorespiratoria/caxumba/dados/caxumba_dados.pdf

54. Freitas DR, Moura E, Araujo G, Cardoso A, Scheidt P, Ferraz E, et al. Investigation of an outbreak of hypersensitivity-type reactions during the 2004 national measles-mumps-rubella vaccination campaign in Brazil. Vaccine [Internet]. 2013;31(6):950-4. Disponível em: http://www.ncbi.nlm.nih.gov/pubmed/23246259

55. Domingues CM, Teixeira AM, Carvalho SM. National immunization program: vaccination, compliance and pharmacovigilance. Rev Inst Med Trop Sao Paulo [Internet]. 2012;54 Suppl 1:S22-7. Disponível em: http://www.ncbi.nlm.nih.gov/pubmed/23011456

56. Health BM of. Casos Confirmados de Rubéola. Brasil, Grandes Regiões e Unidades Federadas. 1997 a 2015. 2015; Disponível em:

http://portalsaude.saude.gov.br/images/pdf/2016/janeiro/27/Casos-conf-de-Rub-ola-1997-2015.pdf

57. Brasil. Vacina Sarampo - Calendário 2015 [Internet]. Ministério da Saúde. 2015 [cited 2015 Dec 16]. Disponível em:

http://portalsaude.saude.gov.br/index.php/o-ministerio/principal/leia-mais-oministerio/424-secretaria-svs/vigilancia-de-a-a-z/sarampo/11-sarampo/10779vacina-sarampo

58. Kennedy AM, Brown CJ, Gust DA. Vaccine beliefs of parents who oppose compulsory vaccination. Public Health Rep [Internet]. 2005 [cited 2017 Oct 16];120(3):252-8. Disponível em: http://www.ncbi.nlm.nih.gov/pubmed/16134564

59. Johansson A, Batty M, Hayashi K, Al Bar O, Marcozzi D, Memish ZA. Crowd and environmental management during mass gatherings. Lancet Infect Dis [Internet]. 2012 Feb [cited 2017 Oct 16];12(2):150-6. Disponível em: http://www.ncbi.nlm.nih.gov/pubmed/22252150

60. APPA. Pet Care Industry Analysis 2016 - Cost \&amp; Trends [Internet]. 2016 [cited 2016 Aug 15]. Disponível em: https://www.franchisehelp.com/industryreports/pet-care-industry-report/

61. Pet Travel • The Kennel Club [Internet]. 2016 [cited 2016 Aug 15]. Disponível 
em: http://www.thekennelclub.org.uk/our-resources/kennel-club-campaigns/pettravel/

62. Davidson RK, Robertson LJ. European pet travel: Misleading information from veterinarians and government agencies. Zoonoses Public Heal. 2012;59(8):57583.

63. Meslin FX, Stohr K, Heymann D. Public health implications of emerging zoonoses. Rev Sci Tech [Internet]. 2000;19(1):310-7. Disponível em: http://www.ncbi.nlm.nih.gov/pubmed/11189723

64. Call for global surveillance of diseases of companion animals. Vet Rec [Internet]. 2012;171(21):519. Disponível em: http://www.ncbi.nlm.nih.gov/pubmed/23180700

65. Brasil. Pesquisa Nacional de Saúde - 2013 [Internet]. Brasília; 2013 [cited 2018 Aug 20]. Disponível em: https://biblioteca.ibge.gov.br/visualizacao/livros/liv94074.pdf

66. Brasil. Pesquisa Nacional de Saúde [Internet]. Rio de Janeiro; 2015 [cited 2016 Jul 7]. p. 104. Disponível em:

http://biblioteca.ibge.gov.br/visualizacao/livros/liv94074.pdf

67. Comac. Radar Pet [Internet]. 2014. Disponível em: http://www.comacvet.org.br/novo/dados-de-mercado

68. Brazil. Leishmaniose visceral - Casos confirmados notificados no Sistema de Informação de Agravos de Notificação - SINAN - São Paulo [Internet]. Brazilian Ministry of Health. 2016 [cited 2016 Aug 1]. Disponível em: http://tabnet.datasus.gov.br/cgi/tabcgi.exe?sinannet/cnv/leishvsp.def

69. Harhay MO, Olliaro PL, Costa DL, Costa CHN. Urban parasitology: visceral leishmaniasis in Brazil. Trends Parasitol. 2011;27(9):403-9.

70. Ciaravolo RM de C, de Oliveira SS, Hiramoto RM, Henriques L de F, Taniguchi HH, Viviani Junior A, et al. Epidemiological Classification of Cities According to the Program of Surveillance and Control of Visceral Leishmaniasis in the State of São Paulo, Updated in december 2014. BEPA, Bol epidemiol paul [Internet]. 2015 [cited 2016 Aug 2];12(143):9-22. Disponível em: http://www.saude.sp.gov.br/resources/ccd/homepage/bepa/edicao2015/edicao_143_-_novembro_3.pdf

71. Oliveira AM, Vieira CP, Dibo MR, Guirado MM, Rodas LAC, ChiaravallotiNeto F. Dispersal of Lutzomyia longipalpis and expansion of canine and human visceral leishmaniasis in São Paulo State, Brazil. Acta Trop. 2016;164:233-42.

72. Gomes de Oliveira V, Alves L, Da Silva Junior V. Transmission routes of visceral leishmaniasis in mammals. Cienc Rural. 2015;45(9):1622-8. 
73. Karkamo V, Kaistinen A, Näreaho A, Dillard K, Vainio-Siukola K, Vidgrén G, et al. The first report of autochthonous non-vector-borne transmission of canine leishmaniosis in the Nordic countries. Acta Vet Scand [Internet]. 2014;56(1):84. Disponível em: http://www.actavetscand.com/content/56/1/84

74. Esch KJ, Petersen CA. Transmission and epidemiology of zoonotic protozoal diseases of companion animals. Clin Microbiol Rev [Internet]. 2013;26(1):5885. Disponível em: http://www.ncbi.nlm.nih.gov/pubmed/23297259

75. APPA. Pet Industry Market Size \&amp; Ownership Statistics [Internet]. 2016 [cited 2016 Aug 15]. Disponível em:

http://www.americanpetproducts.org/press_industrytrends.asp

76. Maia C, Cardoso L. Spread of Leishmania infantum in Europe with dog travelling. Vet Parasitol. 2015;213(1):2-11.

77. G1 Santos. Após morte de irmãos, profissionais têm capacitação sobre leishmaniose. Globo Network [Internet]. 2016; Disponível em:

http://g1.globo.com/sp/santos-regiao/noticia/2016/12/apos-morte-de-irmaosprofissionais-tem-capacitacao-sobre-leishmaniose.html

78. Salgueiro JHP de B, Montenegro SMGL, Pinto EJ de A, Silva BB da, Souza WM de, Oliveira LMM de. Influence of oceanic-atmospheric interactions on extreme events of daily rainfall in the Sub-basin 39 located in Northeastern Brazil. RBRH [Internet]. 2016 Dec [cited 2017 Aug 17];21(4):685-93. Disponível em: http://www.scielo.br/scielo.php?script=sci_arttext\&pid=S231803312016000400685\&lng=en\&tlng=en

79. Griffies WS, Richards M, Chicarelli M, Ernst A, Harrell A, Stites D, et al. Health Care Infrastructure Post-Katrina: Disaster Planning to Return Health Care Workers to Their Home Communities. Psychiatr Serv [Internet]. 2010 Jan [cited 2017 Aug 17];61(1):70-3. Disponível em:

http://psychiatryonline.org/doi/abs/10.1176/ps.2010.61.1.70

80. Kouadio IK, Aljunid S, Kamigaki T, Hammad K, Oshitani H. Infectious diseases following natural disasters: prevention and control measures. Expert Rev Anti Infect Ther [Internet]. 2012 Jan 10 [cited 2017 Aug 18];10(1):95-104. Disponível em: http://www.ncbi.nlm.nih.gov/pubmed/22149618

81. Epstein PR. Climate change and emerging infectious diseases. Microbes Infect [Internet]. 2001 Jul [cited 2017 Aug 18];3(9):747-54. Disponível em: http://linkinghub.elsevier.com/retrieve/pii/S1286457901014290

82. Gundacker ND, Rolfe RJ, Rodriguez JM. Infections associated with adventure travel: A systematic review. 2017 [cited 2017 Aug 21]; Disponível em: http://www.travelmedicinejournal.com/article/S1477-8939(17)30041-8/pdf

83. WHO | Schistosomiasis. WHO [Internet]. 2017 [cited 2017 Aug 22]; Disponível em: http://www.who.int/mediacentre/factsheets/fs115/en/ 
84. Brazil. TabNet Win32 3.0: PCE - Programa de Controle da Esquistossomose Brasil [Internet]. Brazilian Ministry of Health. 2017 [cited 2017 Aug 22].

Disponível em:

http://tabnet.datasus.gov.br/cgi/tabcgi.exe?sinan/pce/cnv/pcebr.def

85. Brazil. A estação chuvosa do Norte da Região Nordeste terminará com Déficit Pluviométrico e Hídrico. Infoclima [Internet]. 2017 [cited 2017 Aug 21];24(3). Disponível em: http://infoclima.cptec.inpe.br/

86. Outbreak of urogenital schistosomiasis in Corsica (France): an epidemiological case study. Lancet Infect Dis [Internet]. 2016 Aug 1 [cited 2017 Sep 25];16(8):971-9. Disponível em: http://www.sciencedirect.com/science/article/pii/S1473309916001754?via\%3Di hub

87. Schistosomiasis transmission in Europe. Lancet Infect Dis [Internet]. 2016 Aug 1 [cited 2017 Sep 25];16(8):878-80. Disponível em: http://www.sciencedirect.com/science/article/pii/S1473309916300615?via\%3Di hub

88. Brazil. Dados do Anuário do Transporte Aéreo [Internet]. Agência Nacional de Aviação Civil. Brasília; 2016 [cited 2017 Apr 25]. Disponível em: http://www.anac.gov.br/assuntos/dados-e-estatisticas/dados-do-anuario-dotransporte-aereo

89. Chaves T do SS, Alves JR, Lopes MH. Pre-travel counselling in Brazil. Travel Med Infect Dis [Internet]. 2015 Jul [cited 2017 Apr 27];13(4):340-1.

Disponível em: http://linkinghub.elsevier.com/retrieve/pii/S1477893915000423

90. Horvath LL, Murray CK, Dooley DP, J T. Effect of Maximizing a Travel Medicine Clinic-s Prevention Strategies. J Travel Med [Internet]. 2006 Mar 8 [cited 2017 Apr 27];12(6):332-7. Disponível em: https://academic.oup.com/jtm/article-lookup/doi/10.2310/7060.2005.12606

91. Brazil. Travel Medicine Clinics - Anvisa [Internet]. 2017 [cited 2017 Mar 16]. Disponível em: http://portal.anvisa.gov.br/centros-de-orientacao-do-viajante

92. dos Santos RP, Konkewicz LR, Nagel FM, Lisboa T, Xavier RC, Jacoby T, et al. Changes in hand hygiene compliance after a multimodal intervention and seasonality variation. Am J Infect Control [Internet]. 2013 Nov [cited 2018 Feb 19];41(11):1012-6. Disponível em: http://www.ncbi.nlm.nih.gov/pubmed/23972518

93. Brazil. Demanda e Oferta do Transporte Aéreo - ANAC [Internet]. ANAC. 2016 [cited 2017 Apr 25]. p. 51. Disponível em: http://www.anac.gov.br/assuntos/dados-e-estatisticas/demanda-e-oferta-dotransporte-aereo

94. Brazil. Saúde do Viajante [Internet]. Brasília: ANVISA; 2012 [cited 2017 May 
2]. 14 p. Disponível em:

https://sispafra.anvisa.gov.br/sispaf/pdf/guia_de_saude_do_viajante.pdf

95. Brazil. Viajante BR [Internet]. Brazilian Ministry of Health. 2014 [cited 2017

May 2]. Disponível em: http://portalsaude.saude.gov.br/index.php/o-

ministerio/principal/secretarias/svs/viajante

96. Vilkman K, Pakkanen SH, Lääveri T, Siikamäki H, Kantele A. Travelers' health problems and behavior: prospective study with post-travel follow-up. BMC Infect Dis [Internet]. 2016 Jul 13 [cited 2017 Apr 28];16:328. Disponível em: http://www.ncbi.nlm.nih.gov/pubmed/27412525

97. Dash AP, Bhatia R, Sunyoto T, Mourya DT. Emerging and re-emerging arboviral diseases in Southeast Asia. J Vector Borne Dis [Internet]. [cited 2017 Apr 28];50(2):77-84. Disponível em:

http://www.ncbi.nlm.nih.gov/pubmed/23995308

98. Nali LH da S, Fujita DM, Salvador FS, Fink MCD da S, Andrade HF de, Pannuti CS, et al. Potential measles transmission risk in mass gatherings: Are we safe for the Olympic games-Rio 2016? J Travel Med [Internet]. 2016 Apr [cited 2016 Jun 17];23(4). Disponível em:

http://www.ncbi.nlm.nih.gov/pubmed/27178161

99. Aggleton P, Bell SA, Kelly-Hanku A. 'Mobile men with money': HIV prevention and the erasure of difference. Glob Public Health [Internet]. 2014 Mar 16 [cited 2017 Apr 28];9(3):257-70. Disponível em:

http://www.ncbi.nlm.nih.gov/pubmed/24593152

100. Igreja RP. Medicina de Viagem: uma nova área de atuação para o especialista em Doenças Infecciosas e Parasitárias. Rev Soc Bras Med Trop [Internet]. 2003 Jul [cited 2017 Apr 27];36(4):539-40. Disponível em: http://www.scielo.br/scielo.php?script=sci_arttext\&pid=S0037$86822003000400020 \& \operatorname{lng}=$ pt\&nrm=iso\&tlng=en

101. Bühler S, Rüegg R, Steffen R, Hatz C, Jaeger VK. A Profile of Travelers-An Analysis From a Large Swiss Travel Clinic. J Travel Med [Internet]. 2014 Sep 1 [cited 2018 Feb 1];21(5):324-31. Disponível em: http://www.ncbi.nlm.nih.gov/pubmed/24934830

102. Quality A for HR and, Merrina F, Gagnayre R, Bouchaud O. A descriptive study of advising practices during travel health consultations in France. J Travel Med [Internet]. 2017 Sep 1 [cited 2017 Jul 24];25(5):582-602. Disponível em: http://fdslive.oup.com/www.oup.com/pdf/production_in_progress.pdf

103. Rowe K, Chaves N, Leder K. Challenges to providing pre-travel care for travellers visiting friends and relatives: an audit of a specialist travel medicine clinic. J Travel Med [Internet]. 2017 Sep 1 [cited 2018 Feb 1];24(5). Disponível em: 
http://academic.oup.com/jtm/article/doi/10.1093/jtm/tax038/3954786/Challenge s-to-providing-pretravel-care-for

104. Rodrigo Saez L, Riestra Menendez S, Fernandez Rodriguez E, Fernandez Velazquez MR, Garcia Alonso S, Lauret Brana ME. Epidemiological study of the prevalence of Helicobacter pylori infection in the general population in Asturias, Spain. Rev Esp Enferm Dig [Internet]. 1997;89(7):511-22. Disponível em: http://www.ncbi.nlm.nih.gov/pubmed/9265837 


\section{ANEXO}

\section{FACULDADE DE MEDICINA DA UNIVERSIDADE DE SÃO PAULO - FMUSP}

Contanusçlo do Parecer. 743.367

Considerações sobre os Termos de apresentação obrigatória:

O estudo é baseado em levantamento da literatura sobre normas e, portanto, näo há necessidade da aplicação do TCLE.

Recomendaçöes:

Conclusões ou Pendências e Lista de Inadequaçöes:

Não há pendências.

Situação do Parecer:

Aprovado

Necessita Apreciaçäo da CONEP:

Não

Consideraçöes Finais a critério do CEP:

aprovado

SAO PAULO, 08 de Agosto de 2014

Assinado por:

Roger Chammas

(Coordenador)

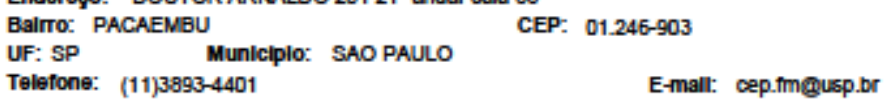

